\title{
FOREST ADAPTATION AND TRANSITION IN THE EASTERN UNITED STATES UNDER CLIMATE CHANGE: A FOREST LANDSCAPE MODELING METHOD
}

\author{
A Dissertation \\ presented to \\ the Faculty of the Graduate School \\ at the University of Missouri-Columbia
}

In Partial Fulfillment

of the Requirements for the Degree

Doctor of Philosophy

by

JACOB S. FRASER

Dr. Hong He, Dissertation Supervisor

JULY 2018 
The undersigned, appointed by the Dean of the Graduate School, have examined the dissertation entitled:

FOREST ADAPTATION AND TRANSITION IN THE EASTERN UNITED STATES UNDER CLIMATE CHANGE: A FOREST LANDSCAPE MODELING METHOD

\author{
presented by Jacob S. Fraser, \\ a candidate for the degree of doctor of philosophy, \\ and hereby certify that, in their opinion, it is worthy of acceptance.
}

Dr. Hong He

Dr. Clayton Blodgett

Dr. David Larsen

Dr. Stephen Shifley

Dr. Frank Thompson 


\section{ACKNOWLEDGEMENTS}

I owe a special thanks to my advisor, Dr. Hong He. As an undergraduate I took Hong's GIS and landscape ecology classes which immediately appealed to my interests in both forest ecology and computer science. This interest led to the pursuit of my graduate degrees in natural resources and eventually to the work presented here. This work would also not be possible without the contribution and assistance of my committee members, Drs. Frank Thompson, Steve Shifley, Dave Larsen, and Clayton Blodgett. I would also like to thank my colleagues Wen Wang and Bill Dijak. Their support and advice has been indispensable over the past five years. In addition, thank you to the current and former members of the GIS and Spatial Analysis Lab in the School of Natural Resources.

I wish to acknowledge and thank several sources of funding and support for the research presented here.

Department of Interior's Northeast Climate Adaptation Science Center

US Forest Service, Northern Research Station

Gulf Coastal Plains and Ozarks Landscape Conservation Cooperative 


\section{TABLE OF CONTENTS}

ACKNOWLEDGEMENTS ........................................................................... ii

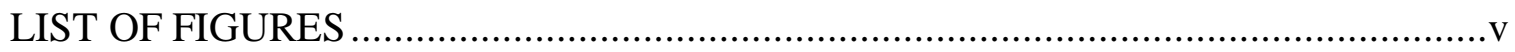

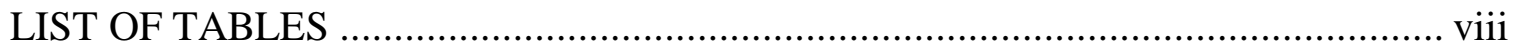

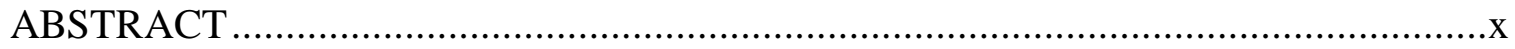

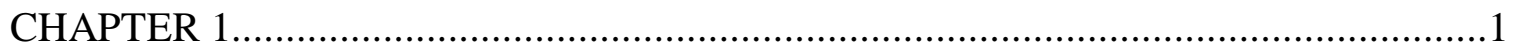

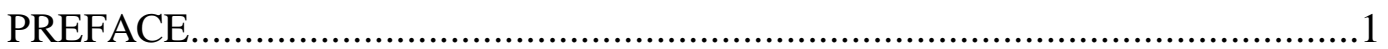

CHAPTER DESCRIPTIONS ..............................................................

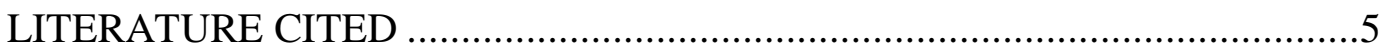

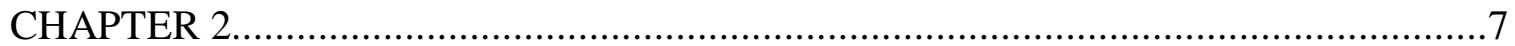

ESTIMATING THE POTENTIAL IMPACT OF CLIMATE CHANGE ON FOREST ECOSYSTEM TRANSITION IN THE EASTERN UNITED STATES

INTRODUCTION ...........................................................................

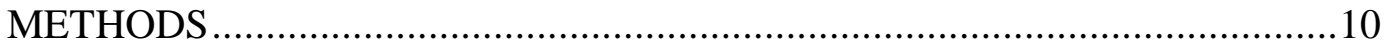

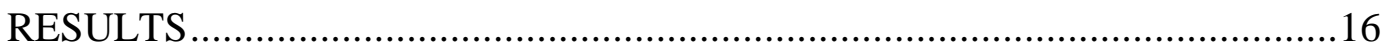

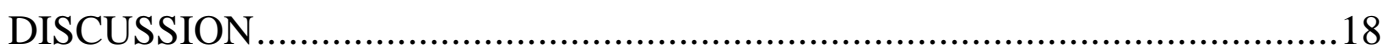

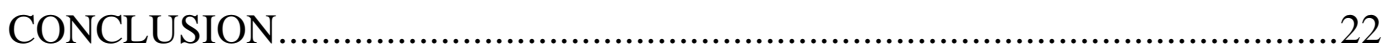

LITERATURE CITED .................................................................... 23

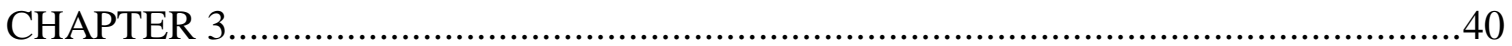




\section{A PROBABILITY BASED METHOD TO ESTIMATE FIRE DISTURBANCE MORTALITY WITHIN A FOREST LANDSCAPE MODEL}

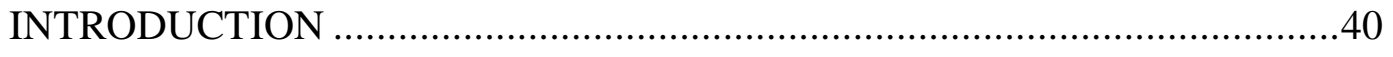

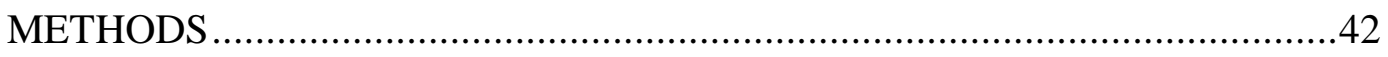

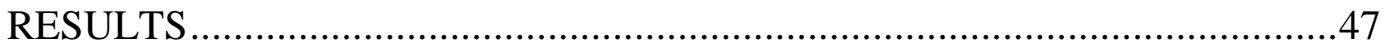

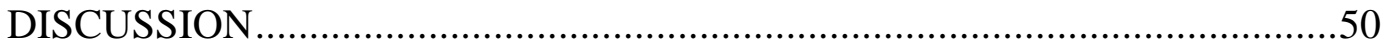

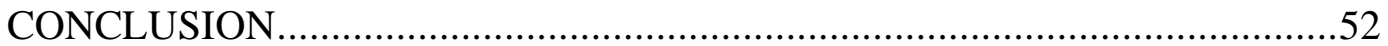

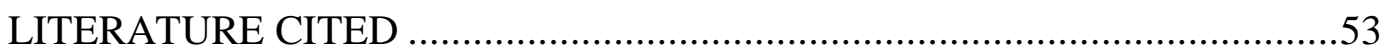

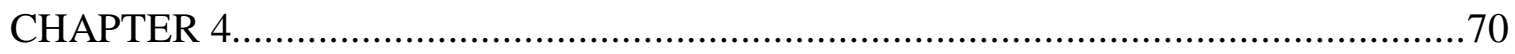

USING A FOREST LANDSCAPE MODEL TO SIMULATE CLIMATE CHANGE ADAPTATION STRATEGIES IN CENTRAL HARDWOOD AND SOUTHERN PINE FORESTS

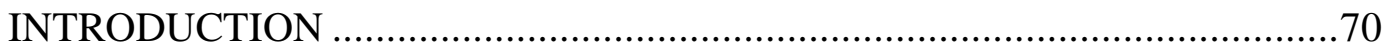

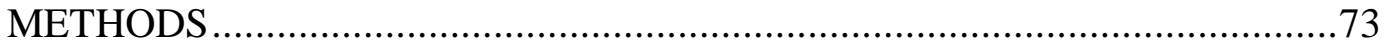

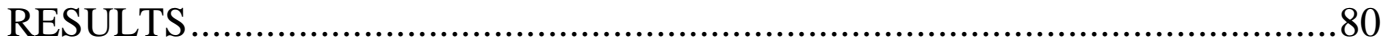

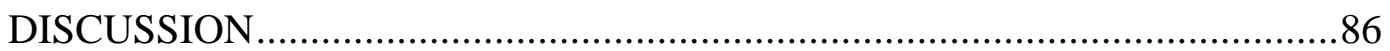

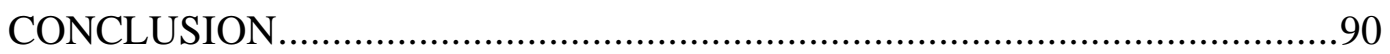

LITERATURE CITED ................................................................... 92

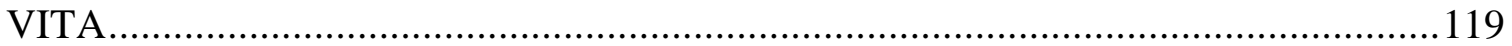




\section{LIST OF FIGURES}

\section{CHAPTER 2}

Figure 1. Map of ecological subsections of the Eastern United States.

Figure 2. Percent change in mean total biomass when compared to results under the current climate for five GCMs by ecological subsection.

Figure 3. Trajectories of absolute change in total biomass under five GCMs compared to

current climate in six selected ecological subsections. .35

Figure 4. Percent change in mean total stems compared to results under the current climate for five GCMs by ecological subsection.

Figure 5. Percent change in mean total basal area when compared to results under the current climate for five GCMs by ecological subsection.

Figure 6. Results from regression tree analysis

Figure 7. Map showing the natural community type transition score (NCTscore) for each ecological subsection under five GCMs.

\section{CHAPTER 3}

Figure 1. Two ecological sections containing forest inventory plots used for analysis. ...65

Figure 2. Boxplot showing distributions of stem densities within eight diameter groups on Forest Inventory and Analysis plots located within ecological section 223A. Plots that experienced fire within the previous five years $(B U R N, n=67)$ are shown in red and plots with no fire recorded (UNBURN, $\mathrm{n}=1972$ ) are shown in blue.

Figure 3. Boxplot showing distributions of stem densities within eight diameter groups on Forest Inventory and Analysis plots located within ecological section 232B. Plots that experienced fire within the previous five years (BURN, $n=423)$ are shown in red and plots with no fire recorded (UNBURN, $\mathrm{n}=4444$ ) are shown in blue.

Figure 4. Boxplot showing distributions of stem densities within eight diameter groups on simulated landscapes randomly populated with plots from within ecological section 223A. Data from pixels that had fire effects simulated using the new diameter-based probability method (BURN) are shown in red. Data from pixels that had fire effects 
simulated using the previous age cohort-based method (COHORTBURN) are shown in

green. Data from pixels with no fire simulated (UNBURN) are shown in blue. .68

Figure 5. Boxplot showing distributions of stem densities within eight diameter groups on simulated landscapes randomly populated with plots from within ecological section 232B. Data from pixels that had fire effects simulated using the new diameter-based probability method (BURN) are shown in red. Data from pixels that had fire effects simulated using the previous age cohort-based method (COHORTBURN) are shown in green. Data from pixels with no fire simulated (UNBURN) are shown in blue.

\section{CHAPTER 4}

Figure 1. The ecological sections of the Gulf Coastal Plains and Ozark Highlands region.

Figure 2. The total annual precipitation and mean maximum temperature for the study region from four global circulation models using the representative control pathway 4.5 scenario. Dashed black line represents the average of each variable over the years $1980-$ 2009.

Figure 3. The total annual precipitation and mean maximum temperature for the study region from four global circulation models using the representative control pathway 8.5 scenario. Dashed black line represents the average of each variable over the years 1980 2009.

Figure 4. Regions used for summarizing results of importance value and basal area.....109

Figure 5. Total basal area ( $\left.\mathrm{ft}^{2} / \mathrm{acre}\right)$ for the West Gulf Coastal Plain region.

Figure 6. Total basal area $\left(\mathrm{ft}^{2} / \mathrm{acre}\right)$ for the East Gulf Coastal Plain region. 110

Figure 7. Total basal area $\left(\mathrm{ft}^{2} / \mathrm{acre}\right)$ for the Interior Highlands region.

Figure 8 . Total basal area $\left(\mathrm{ft}^{2} / \mathrm{acre}\right)$ for the Mississippi Alluvial Valley region.

Figure 9. Total basal area $\left(\mathrm{ft}^{2} / \mathrm{acre}\right)$ for the Gulf Coast region.

Figure 10. Ellipses containing 1 standard deviation weighted by importance value of white oak for the present-day distribution and under five adaptation scenarios and three climate scenarios. 
Figure 11. Ellipses containing 1 standard deviation weighted by importance value of shortleaf pine for the present-day distribution and under five adaptation scenarios and three climate scenarios.

Figure 12. Ellipses containing 1 standard deviation weighted by importance value of loblolly pine for the present-day distribution and under five adaptation scenarios and three climate scenarios.

Figure 13. Ellipses containing 1 standard deviation weighted by importance value of longleaf pine for the present-day distribution and under five adaptation scenarios and three climate scenarios.

Figure 14. Ellipses containing 1 standard deviation weighted by importance value of slash pine for the present-day distribution and under five adaptation scenarios and three climate scenarios.

Figure 15. Age class importance values for the study area under four adaptation scenarios. 


\section{LIST OF TABLES}

\section{CHAPTER 2}

Table 1. List of variables used in regression tree analysis.

\section{CHAPTER 3}

Table 1. Mean stem densities in trees per acre unit by diameter class from FIA plots $(\mathrm{n}=$ 2039) in ecological section 223A where fire occurred in the previous five years (Burned) or where there is no record of fire on the plot (Unburned). The Wilcox rank-sum test was used to calculate $\mathrm{p}$ values.

Table 2. Mean stem densities in trees per acre unit by diameter class from FIA plots $(\mathrm{n}=$ 4867) in ecological section 232B where fire occurred in the previous five years (Burned) or where there is no record of fire on the plot (Unburned). The Wilcox rank-sum test was used to calculate $\mathrm{p}$ values.

Table 3. Mean stem densities in trees per acre unit by diameter class from 100 replications of simulating a landscape composed of randomly selected FIA plots from the ecological section 223A in LANDIS PRO. Fire mortality was estimated using a diameter based probability function (Burned) and an age-cohort based function (Cohort burned). The Tukey Honest Significant Difference test was used to test pairwise differences in the mean stem density for each diameter category across the three factor levels. Letters next to mean values indicate significant differences at a $\mathrm{p} 0.05$. level.

Table 4. Mean stem densities in trees per acre unit by diameter class from 100 replications of simulating a landscape composed of randomly selected FIA plots from the ecological section 232B in LANDIS PRO. Fire mortality was estimated using a diameter based probability function (Burned) and an age-cohort based function (Cohort burned). The Tukey Honest Significant Difference test was used to test pairwise differences in the mean stem density for each diameter category across the three factor levels. Letters next to mean values indicate significant differences at a p 0.05 . level.

Table 5. Mean number of pixels with presence of each diameter class on landscape containing plots from ecological section 223A and simulated using a diameter based probability function (Probability mortality) and an age-cohort based function (Cohort mortality) in LANDIS PRO. Welch's t-test was used to calculate $\mathrm{p}$ values.

Table 6. Mean number of pixels with presence of each diameter class on landscape containing plots from ecological section 232B and simulated using a diameter based probability function (Probability mortality) and an age-cohort based function (Cohort mortality) in LANDIS PRO. Welch's t-test was used to calculate $\mathrm{p}$ values. 


\section{CHAPTER 4}

Table 1. Table of the 5\% and 95\% percentiles of species establishment probabilities over the entire study area for each species modeled in LINKAGES 3.0 under three climate scenarios. Green shading indicates an increase in SEP compared to current climate, red shading indicates a decrease in modeled SEP compared to current climate.

Table 2. Selected species importance values under each adaptation and climate scenario in the West Gulf Coastal Plain region at year 100. Green shading represents an increase in IV over time, red shading represents a decrease in IV over time, orange shading is the lowest IV for the species across all scenarios, blue shading is the highest IV across all scenarios

Table 3. Selected species importance values under each adaptation and climate scenario in the East Gulf Coastal Plain region at year 100. Green shading represents an increase in IV over time, red shading represents a decrease in IV over time, orange shading is the lowest IV for the species across all scenarios, blue shading is the highest IV across all scenarios....

Table 4. Selected species importance values under each adaptation and climate scenario in the Interior Highlands region at year 100. Green shading represents an increase in IV over time, red shading represents a decrease in IV over time, orange shading is the lowest IV for the species across all scenarios, blue shading is the highest IV across all scenarios.

Table 5. Selected species importance values under each adaptation and climate scenario in the Mississippi Alluvial Valley region at year 100. Green shading represents an increase in IV over time, red shading represents a decrease in IV over time, orange shading is the lowest IV for the species across all scenarios, blue shading is the highest IV across all scenarios.

Table 6. Selected species importance values under each adaptation and climate scenario in the Gulf Coast region at year 100. Green shading represents an increase in IV over time, red shading represents a decrease in IV over time, orange shading is the lowest IV for the species across all scenarios, blue shading is the highest IV across all scenarios. 105 


\title{
FOREST ADAPTATION AND TRANSITION IN THE EASTERN UNITED STATES UNDER CLIMATE CHANGE: A FOREST LANDSCAPE MODELING METHOD
}

\author{
Jacob S. Fraser
}

\begin{abstract}
Forest management is rapidly shifting in focus to address the adaptive capacity of forests under uncertain future climates. Managers and researchers often utilize models to proactively develop strategies for forest adaptation management and in order for these models to provide useful results they must realistically represent a multitude of complex processes. Here we detail a linked-model methodology for predicting the response of forests to climate change over large heterogeneous landscapes under a range of adaptation management scenarios. We used a forest ecosystem process model to simulate forests across the eastern United States under a range of future climate scenarios and found that ecotones between major forest types or natural community types may be the most vulnerable to large declines in biomass due to climate change. We then show that the implementation of a probability-based method for estimating individual tree fire mortality can realistically reproduce conditions observed in field inventory data. Finally, we test the effectiveness of different climate forest adaptation strategies at maintaining or increasing the presence and geographic distribution of species on a heterogeneous landscape under climate change.
\end{abstract}




\section{CHAPTER 1}

\section{PREFACE}

Forests in the eastern United States play an important role in the global carbon cycle.

Forests in the region currently act as carbon sinks, although the persistence of this trend is uncertain over the next century (Dixon et al. 1994; Pan et al. 2011; Jin et al. 2017). Forest management is rapidly shifting in focus to address the need to preserve the role of forests as carbon sinks in the future. The question of how best to achieve this goal is difficult to approach because of the many complex factors involved in predicting the effects forest management will have. The future trajectory of any forest is a function of its past use, anthropogenic management, natural disturbance, and abiotic factors. It is common when formulating management plans to achieve a specific goal to use historical conditions as a benchmark for indicating successfully meeting that goal. In uncertain future climate conditions these historical ranges of conditions may no longer be a feasible, or advisable, target condition (Millar et al. 2007). In addition, management strategies for future adaptation will likely be very different from the status quo and will be difficult to implement across much of the forested land in the eastern United States due to an increasingly subdivided landscape of corporate and private owners among who active forest management participation is low (D’Amato et al. 2011; Shifley et al. 2014).

In the process of developing forest management strategies managers rarely have the benefit of directly observed field experiments to aid in planning. The multitude of interacting processes over long periods of time and large spatial extents make such a field experiment an impossible undertaking. Climate adaptation planning adds in another layer 
of uncertainty requiring examination of multiple possible future climate scenarios. In light of these factors, researchers and managers often employ models to aid in examining the consequences of specific management strategies when interacting with novel climate or disturbance conditions. These models can range from forest yield tables and stocking charts to complex forest landscape models which simulate processes of stand dynamics, disturbance, and distribution at large spatial scales over long time periods (Shifley et al. 2017). Often a coupled-model approach is used to simulate multiple components of an ecological system that is not feasible with just one model. Ecosystem process-based models are often used to examine forest responses under possible future climate conditions due to their more mechanistic representations of how site-level biogeochemistry cycles effect forest demographic and stand dynamics. Few examples within this class of model incorporate spatial processes due to computational limitations (He 2008). Therefore, forest landscape models have been developed to in order to address questions of how spatially-interactive processes can effect site-level stand processes. This class of model incorporates multiple natural and human-caused processes that are spatially-interactive and spatially-explicit while still simulating site-level forest stand dynamics. The purpose of this dissertation is to detail several aspects of a coupledmodel approach to assessing forest adaptation and response to climate change over a large area in the eastern United States. 


\section{CHAPTER DESCRIPTIONS}

\section{Chapter 2}

This chapter describes the use of a hybrid empirical-physiological forest growth model, LINKAGES 3.0, to model the response of existing forests across the eastern United States to a range of possible future climate scenarios. I describe the process of using large-scale data products to provide representative conditions of climate, soil, and forest plots within 460 ecological subsections. Using the simulations from the model over the next 100 years I identify regions that are projected to be vulnerable to possible conversion from forest to either a woodland or savanna natural community type. Using a regression tree analysis of variance approach I identify the soil and climatic variables contributing most to variance within modeled forest biomass amounts.

\section{Chapter 3}

Within forest landscape models site-level processes directly interact to control forest succession. The cumulative effects of these interactions are commonly aggregated to larger areas to assess the landscape-scale response forests. In order to more realistically represent the site-level response of fire within the forest landscape model LANDIS PRO I implemented a probability-based calculation of mortality for individual trees following fire. I show that forest inventory data supports the hypothesis of a partial reduction in small-diameter trees following low-intensity fires. By calibrating the fire-effect portion of LANDIS PRO using independent forest inventory data and available literature I was able to reproduce this pattern of mortality in two sample landscapes representing two different 
forest types. In addition, I show that the probability-based fire effects method can have a significant effect on the representation of forest diameter classes at the landscape-scale.

\section{Chapter 4}

Various climate adaptation management strategies have been proposed to mitigate the possible negative effects faced by forests from global climate change. This chapter describes the process of using a forest landscape model to test the effect on species distribution and forest structure of five adaptation strategies over 100 years in the Gulf Coastal Plains and Ozarks region of the eastern United States. I show that a highly intensive transition management strategy maintains a diverse forest age-structure and favors climate-adapted species such as loblolly pine, shortleaf pine, and white oak. Other adaptation strategies that promoted forest resistance or resilience were more limited in effectiveness by region or species. 


\section{LITERATURE CITED}

D’Amato, A.W., Bradford, J.B., Fraver, S., and Palik, B.J. 2011. Forest management for mitigation and adaptation to climate change: Insights from long-term silviculture experiments. For. Ecol. Manage. 262(5): 803-816. Elsevier B.V. doi:10.1016/j.foreco.2011.05.014

Dixon, R.K., Brown, S., Houghton, R.A., Solomon, A.M., Trexler, M.C., and Wisniewski, J. 1994. Carbon pools and flux of global forest ecosystems. Science (80-. ). 263(5144): 185-190. doi:10.1126/science.263.5144.185.

He, H.S. 2008. Forest landscape models: Definitions, characterization, and classification. For. Ecol. Manage. 254(3): 484-498. Available from http://www.scopus.com/inward/record.url?eid=2-s2.038349094174\&partnerID=40\&md5=6fc8e79b722aa2b4b281211c684f7267.

Jin, W., He, H.S., Thompson, F.R., Wang, W.J., Fraser, J.S., Shifley, S.R., Hanberry, B.B., and Dijak, W.D. 2017. Future forest aboveground carbon dynamics in the central United States: the importance of forest demographic processes. Sci. Rep. 7(August 2016): 41821. Nature Publishing Group. doi:10.1038/srep41821.

Millar, C.I., Stephenson, N.L., and Stephens, S.L. 2007. Climate change and forest of the future: Managing in the face of uncertanity. Ecol. Appl. 17(8): 2145-2151. doi:http://dx.doi.org/10.1890/06-1715.1.

Pan, Y., Birdsey, R.A., Fang, J., Houghton, R., Kauppi, P.E., Kurz, W.A., Phillips, O.L., Shvidenko, A., Lewis, S.L., Canadell, J.G., Ciais, P., Jackson, R.B., Pacala, S.W., 
McGuire, A.D., Piao, S., Rautiainen, A., Sitch, S., and Hayes, D. 2011. A Large and Persistent Carbon Sink in the World's Forests. Science (80-. ). 333(6045): 988-993. doi:10.1126/science. 1201609 .

Shifley, S.R., He, H.S., Lischke, H., Wang, W.J., Jin, W., Gustafson, E.J., Thompson, J.R., Thompson, F.R., Dijak, W.D., and Yang, J. 2017. The past and future of modeling forest dynamics: from growth and yield curves to forest landscape models. Landsc. Ecol. Springer Netherlands. doi:10.1007/s10980-017-0540-9.

Shifley, S.R., Keith Moser, W., Nowak, D.J., Miles, P.D., Butler, B.J., Aguilar, F.X., DeSantis, R.D., and Greenfield, E.J. 2014. Five anthropogenic factors that will radically alter forest conditions and management needs in the Northern United States. For. Sci. 60(5): 914-925. doi:10.5849/forsci.13-153. 


\section{CHAPTER 2}

\section{ESTIMATING THE POTENTIAL IMPACT OF CLIMATE CHANGE ON FOREST ECOSYSTEM TRANSITION IN THE EASTERN UNITED STATES}

\section{INTRODUCTION}

The impact of climate change on forest resources is a focus in the latest U.S. National

Climate Assessment (Melillo et al. 2014). Forests are not only a valuable resource for the raw materials they provide, but increasingly, due to other services such as carbon sequestration and their effect on water resources. One expected direct threat to forests in the eastern United States is increased tree mortality due to higher temperatures and water stress due to drought (Joyce et al. 2014). Increasing temperatures and alterations to precipitation patterns are also expected to increase disturbance events such as insect and disease outbreaks, fire, ice storms, high-intensity wind events, and hurricanes (Jentsch, A., Kreyling, J., \& Beierkuhnlein 2007; Allen et al. 2010). Changes to evapotranspiration and other components of the water balance could compound the effects of warming temperatures leading to range shifts across altitude and latitude (Bonan 2008; Iverson et al. 2016). Although the effects of climate change are expected to vary by species (Iverson et al. 2008b), forest ecosystems as a whole are expected to experience changes in productivity and climate-induced biome transition (Grimm et al. 2013).

Several approaches to model the effects of climate on forests have been developed. At the global and continental scale dynamic global vegetation models (DGVMs) simulate mechanistic-based influences of climate on biomes (Sitch et al. 2008; Babst et al. 2013). 
DGVMs are able to model biogeochemical and ecophysiological processes across large temporal and spatial scales at the expense of population, species, and site-level dynamics. Bioclimatic envelope models or species distribution models (SDMs) use statistical relationships to model the response of forests and species in the future at large spatial scales (Iverson et al. 2008b; Singer et al. 2016). SDMs are computationally efficient compared to mechanistic models and are able to model individual species, however, the results are usually presence/absence or relative metric based and do not incorporate ecological knowledge such as species traits or interactions (Dormann et al. 2012). Others have used regression tree based models to estimate site productivity metrics such as site index using climate and soil predictors (Weiskittel et al. 2011; Jiang et al. 2015).

Increasingly, estimating the response of forests to climate change is investigated by applying results from forest stand dynamic models (gap models) which can integrate stand successional dynamics with site properties such as soil and local climatic conditions. Gap models have been used for decades to estimate forest and species response to climate change (Pastor and Post 1988; Dale et al. 2010; Vanderwel and Purves 2014). Many of these models are based on components of the JABOWA model which modeled the growth, establishment, and mortality of individual trees on a small plot (Botkin et al. 1972). More recently, gap models have incorporated finer-scale spatial, demographic, and temporal processes. The model SORTIE uses the location of individual stems as well as crown geometry to simulate competition for light on a plot (Pacala and Canham 1996). The models ZELIG (Urban et al. 1993) and SIBBORK (Brazhnik and Shugart 2016) integrate spatial tracking by dividing the plot into canopy sized grid-cells which can interact with one another. Some models have mixed temporal resolutions in 
order to include finer detail in some processes to capture patterns in events that may not be represented by monthly or yearly aggregations. For example, LINKAGES v.2.2 (Wullschleger et al. 2001) simulates demography and decomposition at an annual timestep while the hydrology and evapotranspiration processes are simulated at a daily timestep. Since the new generation of gap models can include mechanistic representations of growth, mortality, and establishment they can be useful in estimating the response of forest stands to novel climate conditions. These predictions can be scaled to the regional level by aggregating results from multiple replicates at the site-level that encompass a representative range of site conditions (Keenan et al. 2011; Reyer et al. 2014).

We incorporated a variable time step process-based hydrological model, BROOK90 (Federer 1995), into a hybrid empirical-physiological forest growth model, LINKAGES 3.0 (Dijak et al. 2017), to investigate forest response to climate change across the eastern United States. Since climate is an important factor in forest mortality and productivity, we expect that operating at a daily time step will improve the ability of the model to capture the effect of changes in climate patterns, especially drought. In addition, the hybrid design of the forest growth model allows some mechanistic processes within the model which should behave more reliably under novel climate conditions, while still maintaining the ability to track more detailed demographic information about individual trees. This allows the model to be parameterized using existing nation-wide forest and soil inventories to produce a more realistic initial condition. Our objectives were to: 1 ) investigate the response of forest biomass, basal area, and tree density to climatic change across the eastern United States using the model LINKAGES 3.0; 2) identify which variables in the interaction between climate and soil had the most effect on forest 
biomass; and 3) identify which ecological subsections had the highest predicted probability for natural community type transition under novel climate conditions.

\section{METHODS}

\section{Ecological subsections of the eastern United States}

We studied 460 ecological subsections in 14 ecological provinces in the eastern United States described by McNab et al. 2007 (Figure 1).

The entire area contains over 380 million acres of forest made up of spruce-fir, white-redjack pine, and aspen-birch forests in the northern region; oak-hickory and maple-beech forests in the central region; and loblolly-shortleaf pine, longleaf-slash pine, and oak-pine forests in the southern region (Smith et al. 2009). Over 80\% of the forested land is in private ownership with $23 \%$ of that amount in public ownership and $27 \%$ held by corporations (Smith et al. 2009).

\section{Climate projections}

We used daily values for minimum and maximum temperature, precipitation, mean surface wind speed, and incident solar radiation. We used a publicly available, gridded dataset containing each of the desired variables from the year 1980 to 2009 to represent the current climate (Livneh et al. 2013). We used projections of future climate from 2010 to 2099 consisting of spatially-downscaled bias-corrected daily values of minimum and maximum temperature and precipitation from five General Circulation Models (GCMs) that are part of the Coupled Model Intercomparison Project phase 5 (CMIP5) (Reclamation 2013). For mean surface wind speed and incident solar radiation we used CMIP5 outputs from each of the GCM modeling groups (Taylor et al. 2012). We used the 
Representative Concentration Pathway (RCP) 8.5 for each of the GCMs to simulate a high greenhouse gas scenario with little to no mitigation (Riahi et al. 2011). We extracted climate data from the gridded datasets for a representative point for each subsection with the median annual precipitation for the six climate scenarios during their respective time ranges.

\section{Soil properties}

We used the Soil Survey Geographic (SSURGO) Database (Soil Survey Staff 2015) to provide estimates for the properties of soil series within each ecological subsection. Due to the varying number of soil series and areas of ecological subsections, we chose to use the five most abundant series by area excluding those classified as water, rock, or urban. We calculated organic matter and nitrogen content for the soil and for each individual soil layer used thickness, matric potential at field capacity, water content at field capacity, water content at saturation, percent rock, hydraulic conductivity at field capacity, and an exponent for estimating hydraulic conductivity (Clapp and Hornberger 1978).

\section{Initial forest plots}

We used the nationwide Forest Inventory and Analysis (FIA) dataset to provide information about initial forest conditions across the study area (O'Connell et al. 2013). Plots were first filtered by inventory year to only include those which were sampled since 2005. For each ecological subsection 100 plots were randomly chosen from all plots occurring within the subsection. Information about individual tree species and diameter at breast height $(\mathrm{DBH})$ was extracted from the database for the selected subset of plots. In order to account for possible migration under novel climate scenarios we also included 
any species from surrounding subsections in the species list so they were eligible for establishment.

\section{LINKAGES v.3.0}

LINKAGES v3.0 is an individual-based forest gap model that simulates forest dynamics, and water and nutrient cycling at a daily time-step. Many purely process based forest ecosystem models often simulate forest dynamics and productivity lumped by age cohort, functional type, or organ (Jin et al. 2016). LINKAGES uses a hybrid empirical and process-based approach where the biogeochemical processes (water, carbon, and nitrogen) and stand-scale forest dynamics (inter- and intra-species competition, successional trajectories) are process-based while parts of the individual-level processes, such as establishment, growth, and mortality, have empirical components. Individual species in the model have parameterized traits such as drought tolerance, shade tolerance, growth rates, growing degree day requirements, and seed production. This allows the model to include specific species traits when simulating the effect of climate on forest productivity and biogeochemical cycles (Dale et al. 2010).

The original LINKAGES model (v1.0) was developed based on principles of interaction between individual trees and site resources found in the JABOWA class of models (Botkin et al. 1972). The core subroutines of these models simulate how light and moisture availability as well as competition with other individuals constrains the optimum growth of individual stems on a forest plot. Subsequent model developments added functions to simulate nutrient cycling (Aber et al. 1982) and soil moisture balance (Mann and Post 1980). The first version of LINKAGES integrated these modifications in to a single model that simulated forest dynamics and productivity at a monthly time-step 
with feedback from climate, soil, light, demography, decomposition, and nutrient cycling processes (Pastor and Post 1986).

LINKAGES v2.2 updated the model to a daily time-step that modeled evaporation from the soil and canopy evaporation, interception, and transpiration separately as well as replacing the single-layer bucket model of soil hydrology with a multi-layer approach that limited the availability of water in the soil to trees based on individual layer water content and root depth (Wullschleger et al. 2003). In LINKAGES v2.2 each species has a maximum possible diameter growth increment. This growth factor for each individual tree is then scaled based on limitations imposed by soil moisture, temperature, available light, or nutrient availability. If a tree experiences an extended period of limited growth due to these factors it will die. The water cycle is controlled by a routine based on the BROOK90 water balance model (Federer 1995). Using the Shuttleworth and Wallace (1985) method the model takes inputs from the daily climate parameter files to simulates canopy interception and evaporation, transpiration, and evaporation from the soil surface. Any leftover water then enters the soil profile where infiltration is modeled vertically through the layers. A tree's size (seedling, sapling, mature) determines the depth of soil layers which it has access to for water (Wullschleger et al. 2001).

We modified LINKAGES v.2.2 by updating and calibrating maximum growth rates, drought tolerance, nitrogen tolerance, and growing degree day requirements for 62 eastern U.S. tree species (Hanberry et al. n.d., Dijak et al. 2017). For this version of LINKAGES we implemented a stocking-level mortality function which triggers selfthinning in the plot when the total stocking exceeds a certain threshold (Bechtold and Patterson 2005, Dijak et al. 2017). In addition, the water cycle subroutine was updated to 
incorporate changes made to the BROOK90 model since the development of LINKAGES v2.2. The aboveground water balance process now runs at a bi-daily time-step to simulate day and night evaporation and infiltration. The belowground process uses a variable timestep to simulate transpiration and water movement between soil layers (Federer et al. 2003).

We used our updated version of LINKAGES (v.3.0) and simulated the growth of 100 forest plots in each of the 460 ecological subsections under five future climate scenarios and twentieth century climate conditions for 200 years using the randomly chosen FIA plots as initial conditions and the five soils in each subsection to represent a range of growing conditions resulting in over 1.3 million unique model runs. For the current condition we used daily climate data from the years 1950 - 2009 and ran the model for 200 years with the 60 years of climate data looping during that time. For future climate scenarios we used daily climate data from the years 2010 - 2099 and ran the model for 200 years with the 90 years of GCM climate data looping. Outputs from the model include yearly averages across the 100 replications of aboveground biomass by species, tree density by species, basal area by species, evapotranspiration, and dry days.

We used a regression tree ANOVA analysis to assess the effect of climate and soil variables on individual plot biomass (rpart package in R; R Core Team 2016). We used maximum plot biomass as the dependent variable and calculated eight climate index measurements for each of the GCMs as well as eight soil properties for use as predictor variables (Table 1). 
We classified each simulated plot as one of three natural community types (NCT; forest, woodland, or savanna) to identify ecosystem type transitions. The differences between these three NCTs can be characterized many different ways, including species assemblages, disturbance type and frequency, climate, canopy cover, tree density, land use history, and others (Rebertus and Burns 1997; Taft 1997; Nowacki and Abrams 2008). Our objective was to assess the role of climate in possible NCT conversion. Since LINKAGES does not model fire or anthropogenic disturbances and outputs forest stand metrics we chose to classify the NCT of each simulated plot using total basal area $\left(\mathrm{m}^{2} / \mathrm{ha}\right)$ and canopy cover percentage according to guidelines in Nelson (2010). Forest plots were classified as any plots with a basal area greater than $18.4 \mathrm{~m}^{2} /$ ha and canopy coverage of greater than $80 \%$. Woodland plots were classified as any plots where the basal area was in the range of $6.9-18.4 \mathrm{~m}^{2} /$ ha and canopy coverage was in the range of $30-80 \%$. Plots were classified as savanna if the basal area was less than $6.9 \mathrm{~m}^{2} /$ ha and the canopy coverage was less than $30 \%$. After classification, each plot was assigned a score (referred as NCT score in results) based on the transition type. If the NCT did not change a score of 0 was assigned, a plot that changed from a forest to woodland NCT received a score of 1 , a plot that changed from a woodland to a savanna was scored as a 2 , and a plot that changed from a forest to a savanna was scored as a 3. These scores were summed by subsection so the lowest NCT score of zero indicated no NCT transition while the highest possible score of 15 would indicate all plots transitioned from forest to savanna. 


\section{RESULTS}

\section{Projected Changes in Forest Biomass, Basal Area, and Stem Density}

The ACCESS1-0 GCM had the largest mean change in total biomass across the study area $(-8.3 \%)$ while the lowest change occurred under the MRI-CGCM3 GCM (-1.0\%) (Figure 2). The Central Appalachian Broadleaf Forest-Coniferous Forest-Meadow, Central Interior Broadleaf Forest, Laurentian Mixed Forest, and Ouachita Mixed ForestMeadow provinces had total biomass declines of more than $10 \%$ and the smallest change was a $3.6 \%$ decline in total biomass in the Prairie Parkland (Temperate) province. The CanESM2 GCM caused biomass declines in all provinces with the largest being a 10.1\% decline in the Central Interior Broadleaf Forest province and the smallest was a less than $1 \%$ decline in the Central Appalachian Broadleaf Forest-Coniferous Forest-Meadow province. The MRI-CGCM3 GCM had the smallest mean change in total biomass ($1.3 \%$ ) where three provinces had small increases in total biomass and 11 provinces had small decreases with the largest being $-6.3 \%$ in the Central Interior Broadleaf Forest. The GFDL-ESM2M GCM showed a similar pattern of small decreases of total biomass where the largest change was a $-8.3 \%$ decrease in the Central Interior Broadleaf Forest. The MIROC5 GCM had one province with an increase in total biomass while all other provinces had declines of total biomass with the largest being $-11.4 \%$ in the Central Interior Broadleaf Forest.

In three subsections where the highest decreases in total biomass occurred the GCM that had the largest difference was ACCESS1-0. In subsections 231Cd and 231Dd, both within the Southeastern Mixed Forest province, the absolute biomass when compared to the current climate had an average decrease of 50\% (Figure 3). In subsection M211De the 
ACCESS1-0 and MIROC5 GCMS both had average decreases of more than 50\% in biomass. The largest increases in total biomass occurred within the Prairie Parkland (Subtropical) province in subsections 255Ba, 255Cf, and 255Db. In subsection 255Ba the largest mean increase happened under the ACCESS1-0 GCM (+13.2\%). In subsection 255Cf the largest mean increase happened under the CanESM2M GCM (+19.1\%). In $255 \mathrm{Db}$ all GCMs had increases in total biomass greater than $10 \%$ with CanESM2M and MIROC5 both showing greater than $16 \%$ increases.

Stem densities decreased the most under the ACCESS1-0 GCM with an average decline of $32.1 \%$ across the study area. The largest decreases in stem densities occurred in subsections within the Prairie Parkland (Subtropical) and Southeastern Mixed Forest provinces (Figure 4). The smallest change was under the MRI-CGCM3 GCM with an average decline of $7.4 \%$.

Results for changes in total basal area largely followed the same patterns as total biomass. The ACCESS1-0 GCM had the largest change with a 10.8\% mean decrease in total basal area across the study area while the MRI-CGCM3 GCM had the smallest change (-1.7\%). Most of the decreases under the ACCESS1-0 GCM occurred in the southern Central Appalachian Broadleaf Forest and Eastern Broadleaf Forest provinces as well as the Southeastern Mixed Forest and western portion of the Prairie Parkland (Subtropical) provinces (Figure 5).

\section{Effect of Climate and Soil Variables on Biomass}

Seven of 16 variables contributed to stand biomass based on the regression tree model after pruning with a complexity parameter $(\mathrm{CP})$ of 0.01 . The primary split in the 
regression tree model was soil depth and subsequent splits in shallower soils were controlled by either the mean total number of days with precipitation exceeding $10 \mathrm{~mm}$ (R10MM) or mean number of summer days (SU) variables, while in deeper soils the partitions were made by the water content at wilting point (THETAWP) and the hydraulic conductivity exponent (BEXP) variables (Figure 6). After 10 splits the model had an $\mathrm{R}^{2}$ value of $61 \%$.

\section{Natural Community Type Change}

The ACCESS1-0 GCM had the most natural community type transitions. On 137 soils the community type changed from forest under the current climate to woodland and 11 transitioned from woodland to savanna. The lowest number of community type transitions happened under the MRI-CGCM3 GCM with only 17 soils changing from forest to woodland and two changing from woodland to savanna. Most of the NCT changes were focused in the center of the study area near the transition between the Central Appalachian Broadleaf Forest-Coniferous Forest-Meadow, Central Interior Broadleaf Forest, Eastern Broadleaf Forest, and Southeastern Mixed Forest provinces (Figure 7).

\section{DISCUSSION}

Addressing the uncertainty associated with climate change is a major challenge in ecological studies. Here we used a hybrid empirical-physiographic forest model to estimate the effects of a range of climate scenarios on forests over the eastern United States. Responses of total biomass ranged across the climate projections with the largest decreases occurring around ecotones between major forest types or natural community 
types. Using a regression tree analysis we determined that in shallower soils the response of biomass was correlated with variables describing precipitation patterns and growing season maximum temperature. Stem densities declined across all climate scenarios, primarily due to limited regeneration.

\section{Comparisons with Previous Studies}

Solomon (1986) used an early successor to LINKAGES, FORENA to simulate an assemblage of species across a variety of sites in the Eastern United States under novel climate scenarios. Several sites within the Central Interior Broadleaf Forest (CIBF) and the Midwest Broadleaf Forest (MBF) near the Prairie Parkland ecotone were projected to have biomass declines of around 50\%, in the case of central lower Michigan, and near complete loss of forest biomass, as in the cases of central Missouri and central Arkansas. Bachelet et al. (2001) used the biogeography equilibrium model MAPSS to simulate vegetation classifications across the United States under seven GCMs. Five of the GCM scenarios showed a net decrease in the temperate deciduous forest vegetation type and six predicted a net increase of the savanna/woodland vegetation type. Much of the net loss of deciduous forest to savanna/woodland occurred within the CIBF and the MBF. Sitch et al. (2008) compared results from four DGVMs running the SRES A1FI climate scenario. In two of the modeled areas within the CIBF and MBF were predicted to have 20 to 50 percent decreases in plant functional types associated with forests. Frelich and Reich (2010) suggest that the prairie-forest border following the northern border of the prairie parkland ecosystem type will be a region prone to losses of forest ecosystem types as climates become warmer and drier. 
Our results are in general agreement with Solomon (1986), Bachelet et al. (2001), Sitch et al. (2008), and Frelich and Reich (2010) about the location of potential forest ecosystem transition. As expected, forest biomass within the Prairie Parkland provinces was lower than in provinces containing typically forested ecosystems, and declined further under warmer, drier climate scenarios (Figure 3). In agreement with previous studies, under the ACCESS1-0 and CanESM2 GCMs there was a reduction in maximum biomass within the $\mathrm{CIBF}$ and $\mathrm{MBF}$ near the ecotone with the prairie parkland (Figure 4). While we summarized our results at the ecological subsection level, the simulations were performed on individual soils from the SSURGO database which is available as a $10 \mathrm{~m}$ resolution gridded dataset. Other studies that include soil properties generally use soil data that has been aggregated from $10 \mathrm{~km}$ or coarser resolution spatial data. In addition, LINKAGES models the hydrology of a plot using properties of each individual soil layer, while other models typically simplify soils in to either a single or sometimes two-layer representation. Another advantage of LINKAGES is the use of a daily time-scale for climate data. Other estimates of forest productivity or community type at this spatial scale have relied on monthly averages of climate variables for their predictions. The regression tree analysis showed that in shallower soils it was indexes based on daily temperature and precipitation that were the most influential variables. There were no subsections under any of the GCMs where community type transition occurred on all five soils. This suggests that LINKAGES could be used to produce more spatially detailed estimates of areas with potential for community type transition using the finer resolution spatial and climate data available in subsections identified in this study. 


\section{Importance of Integrating Fine Spatial and Temporal Scale Processes}

Forest gap models, and specifically LINKAGES, are based on the underlying assumption that the maximum biomass of an individual tree is dependent on the resources available on a site. LINKAGES has the benefit of using a process-based hydrology module that operates at a sub-daily time-step to model the water balance. This allows the model to account for finer-scale changes in moisture patterns and their subsequent effect on the productivity and mortality in specific combinations of species assemblages and soil characteristics. Using species life history traits, LINKAGES can also account for the effect that changes in the growing season and seasonal temperatures may have on specific species.

LINKAGES also has the benefit of simulating the inter-individual and inter-species forest dynamic interactions on a site. This is important for not only predicting species assemblages under future climates but how forest dynamics will play a role in biomass accumulation.

By combining process-based mechanisms for hydrology and stand dynamics with empirical relationships for species responses LINKAGES has the ability to predict forest responses to novel climate scenarios that may not be possible with statistically based model.

\section{Limitations}

Although forest stand dynamics are simulated in LINKAGES, disturbance processes that are important in shaping some forested ecosystems are not, such as fire, harvest, wind, diseases, and pests (Vanderwel and Purves 2014). By omitting these factors LINKAGES 
is unable to reproduce species assemblages found in some systems driven by frequent disturbances. While LINKAGES incorporates nitrogen and carbon cycles, these are simplified processes. The carbon cycle within the model does not have a mechanism for including the effects of varying atmospheric $\mathrm{CO}_{2}$ concentrations. Tree height and diameter growth increments are controlled by site and stand dynamics, however, individual biomass accumulation relies on a simple allometric equation that may not be as accurate as physiological models that simulate carbon and biomass using mechanistic processes.

\section{CONCLUSION}

We identified potential areas where conditions under future climate may change enough to alter the productivity of forests at magnitudes that could drive transitions between natural community types. In these areas of transition we identified characteristics of soil and climate that are likely the drivers of this response by limiting regeneration within forests. 


\section{LITERATURE CITED}

Aber, J.D., Melillo, J.M., and Federer, C.A. 1982. Predicting the Effects of Rotation Length, Harvest Intensity, and Fertilization on. For. Sci. 28(1): 31-45.

Allen, C.D., Macalady, A.K., Chenchouni, H., Bachelet, D., McDowell, N., Vennetier, M., Kitzberger, T., Rigling, A., Breshears, D.D., Hogg, E.H. (Ted), Gonzalez, P., Fensham, R., Zhang, Z., Castro, J., Demidova, N., Lim, J.-H., Allard, G., Running, S.W., Semerci, A., and Cobb, N. 2010. A global overview of drought and heatinduced tree mortality reveals emerging climate change risks for forests. For. Ecol. Manage. 259(4): 660-684. doi:10.1016/j.foreco.2009.09.001.

Babst, F., Poulter, B., Trouet, V., Tan, K., Neuwirth, B., Wilson, R., Carrer, M., Grabner, M., Tegel, W., Levanic, T., Panayotov, M., Urbinati, C., Bouriaud, O., Ciais, P., and Frank, D. 2013. Site- and species-specific responses of forest growth to climate across the European continent. Glob. Ecol. Biogeogr. 22(6): 706-717. doi:10.1111/geb.12023.

Bachelet, D., Neilson, R.P., Lenihan, J.M., and Drapek, R.J. 2001. Climate change effects on vegetation distribution and carbon budget in the United States. Ecosystems 4(3): 164-185. doi:10.1007/s10021-001-0002-7.

Bechtold, W.A., and Patterson, P.A. 2005. The Enhanced Forest Inventory and Analysis Program - National Sampling Design and Estimation Procedures. Southern Research Station.

Bonan, G.B. 2008. Forests and climate change: forcings, feedbacks, and the climate 
benefits of forests. Science (80-. ). 320(5882): 1444-1449.

doi:10.1126/science.1155121.

Botkin, D., Janak, J., and Wallis, J. 1972. Some ecological consequences of a computer model of forest growth. J. Ecol. 60(3): 849-872. doi:10.2307\%2F2258570.

Brazhnik, K., and Shugart, H.H. 2016. SIBBORK: A new spatially-explicit gap model for boreal forest. Ecol. Modell. 320: 182-196. Elsevier B.V. doi:10.1016/j.ecolmode1.2015.09.016.

Clapp, R.B., and Hornberger, G.M. 1978. Empirical equations for some soil hydraulic properties. Water Resour. Res. 14(4): 601-604. doi:10.1029/WR014i004p00601.

Dale, V.H., Tharp, M.L., Lannom, K.O., and Hodges, D.G. 2010. Modeling transient response of forests to climate change. Sci. Total Environ. 408(8): 1888-901. Elsevier B.V. doi:10.1016/j.scitotenv.2009.11.050.

Dijak, W.D., Hanberry, B.B., Fraser, J.S., He, H.S., Wang, W.J., and Thompson, F.R. 2017. Revision and application of the LINKAGES model to simulate forest growth in central hardwood landscapes in response to climate change. Landsc. Ecol.: 1-20. doi:10.1007/s10980-016-0473-8.

Dormann, C.F., Schymanski, S.J., Cabral, J., Chuine, I., Graham, C., Hartig, F., Kearney, M., Morin, X., Römermann, C., Schröder, B., and Singer, A. 2012. Correlation and process in species distribution models: Bridging a dichotomy. J. Biogeogr. 39(12): 2119-2131. doi:10.1111/j.1365-2699.2011.02659.x.

Federer, C. a., Vörösmarty, C., and Fekete, B. 2003. Sensitivity of Annual Evaporation to 
Soil and Root Properties in Two Models of Contrasting Complexity. J.

Hydrometeorol. 4(6): 1276-1290. doi:10.1175/1525-

7541(2003)004<1276:SOAETS>2.0.CO;2.

Federer, C.A. 1995. BROOK90: a simulation model for evaporation, soil water and streamflow. US Department of Agriculture, Forest Service, Durham, NH.

Frelich, L.E., and Reich, P.B. 2010. Will environmental changes reinforce the impact of global warming on the prairie- Forest border of central North America? Front. Ecol. Environ. 8(7): 371-378. doi:10.1890/080191.

Grimm, N.B., Chapin, F.S., Bierwagen, B., Gonzalez, P., Groffman, P.M., Luo, Y., Melton, F., Nadelhoffer, K., Pairis, A., Raymond, P.A., Schimel, J., and Williamson, C.E. 2013. The impacts of climate change on ecosystem structure and function. Front. Ecol. Environ. 11(9): 474-482. doi:10.1890/120282.

Hanberry, B.B., Thompson III, F.R., Dijak, W.D., Fraser, J.S., and He, H.S. (n.d.). Changes in individual tree species establishment and growth under future climate change in the eastern United States.

Iverson, L.R., Prasad, A.M., Matthews, S.N., and Peters, M. 2008. Estimating potential habitat for 134 eastern US tree species under six climate scenarios. For. Ecol. Manage. 254(3): 390-406. doi:10.1016/j.foreco.2007.07.023.

Iverson, L.R., Thompson, F.R., Matthews, S., Peters, M., Prasad, A., Dijak, W.D., Fraser, J., Wang, W.J., Hanberry, B., He, H., Janowiak, M., Butler, P., Brandt, L., and Swanston, C. 2016. Multi-model comparison on the effects of climate change on 
tree species in the eastern U.S.: results from an enhanced niche model and processbased ecosystem and landscape models. Landsc. Ecol. Springer Netherlands. doi:10.1007/s10980-016-0404-8.

Jentsch, A., Kreyling, J., \& Beierkuhnlein, C. 2007. A new generation of climate change experiments : events , not trends. Front. Ecol. Environ. 5(7): 365-374. doi:10.1890/1540-9295(2007)5[365:ANGOCE]2.0.CO;2.

Jiang, H., Radtke, P.J., Weiskittel, A.R., Coulston, J.W., and Guertin, P.J. 2015. Climateand soil-based models of site productivity in eastern US tree species. Can. J. For. Res. 45(3): 325-342. doi:10.1139/cjfr-2014-0054.

Jin, W., He, H.S., and Thompson III, F.R. 2016. Are more complex physiological models of forest ecosystems better choices for plot or landscape predictions ? Environ. Model. Softw. 75: 1-14. Elsevier Ltd. doi:10.1016/j.envsoft.2015.10.004.

Joyce, L.A., Running, S.W., Breshears, D.D., Dale, V.H., Malmsheimer, R.W., Sampson, R.N., Sohngen, B., and Woodall, C.W. 2014. Ch. 7: Forests. In Climate Change Impacts in the United States: The Third National Climate Assessment. Edited by J.M. Melillo, T.C. Richmond, and G.W. Yohe. U.S. Global Change Research Program. pp. 175-194. doi:10.7930/J0Z60KZC.

Keenan, T., Maria Serra, J., Lloret, F., Ninyerola, M., and Sabate, S. 2011. Predicting the future of forests in the Mediterranean under climate change, with niche- and process-based models: CO2 matters! Glob. Chang. Biol. 17(1): 565-579. doi:10.1111/j.1365-2486.2010.02254.x. 
Livneh, B., Rosenberg, E. a., Lin, C., Nijssen, B., Mishra, V., Andreadis, K.M., Maurer, E.P., and Lettenmaier, D.P. 2013. A long-term hydrologically based dataset of land surface fluxes and states for the conterminous United States: Update and extensions. J. Clim. 26(23): 9384-9392. doi:10.1175/JCLI-D-12-00508.1.

Mann, L.K., and Post, W.M. 1980. Modeling the effect of drought on forest growth and composition. Bull. Ecol. Soc. Am. 61: 80. Available from http://www.jstor.org/stable/20166238.

McNab, W.H., Cleland, D.T., Freeouf, J.A., Keys, Jr., J.E., Nowacki, G.J., and Carpenter, C.A. 2007. Description of ecological subregions: sections of the conterminous United States. In Gen. Tech. Report WO-76B. U.S. Department of Agriculture, Forest Service, Washington, DC.

Melillo, J., Richmond, T., and Yohe, G. (Editors). 2014. Climate Change Impacts in the United States: The Third National Climate Assessment. U.S. Global Change Research Program. doi:10.7930/J0Z31WJ2.

Nelson, P. 2010. The Terrestrial Natural Communities of Missouri. Missouri Department of Conservation, Jefferson City, MO.

Nowacki, G.J., and Abrams, M.D. 2008. The Demise of Fire and "Mesophication" of Forests in the Eastern United States. Bioscience 58(2): 123. doi:10.1641/B580207.

O’Connell, B.M., LaPoint, E.B., Turner, J.A., Ridley, T., Boyer, D., Wilson, A.M., Waddell, K.L., Pugh, S.A., and Conkling, B.L. 2013. The Forest Inventory and Analysis Database: Database Description and Users Manual Version 5.1.6 for Phase 
2. In Forest Service, North Central. Available from

http://www.fia.fs.fed.us/library/database-

documentation/historic/ver1/FIADB_v17_021804.pdf [accessed 16 April 2014].

Pacala, S., and Canham, C. 1996. Forest models defined by field measurements: estimation, error analysis and dynamics. Ecol. .... Available from http://www.esajournals.org/doi/abs/10.2307/2963479 [accessed 24 August 2012].

Pastor, J., and Post, W. 1986. Influence of climate, soil moisture, and succession on forest carbon and nitrogen cycles. Biogeochemistry 2(1): 3-27. Available from http://link.springer.com/article/10.1007/BF02186962 [accessed 18 March 2014].

Pastor, J., and Post, W. 1988. Response of northern forests to CO2-induced climate change. Nature 334: 55-58. Available from http://www.nature.com/nature/journal/v334/n6177/abs/334055a0.html [accessed 16 October 2014].

Rebertus, A.J., and Burns, B.R. 1997. The importance of gap processes in the development and maintenance of oak savanas and dry forest. J. Ecol. 85(5): 635645.

Reclamation. 2013. Downscaled CMIP3 and CMIP5 Climate Projections: Release of Downscaled CMIP5 Climate Projections, Comparison with Preceding Information, and Summary of User Needs. U.S. Department of the Interior, Bureau of Reclamation, Technical Service Center, Denver, Colorado. Available from http://gdodcp.ucllnl.org/downscaled_cmip_projections/techmemo/downscaled_climate.pdf. 
Reyer, C., Lasch-Born, P., Suckow, F., Gutsch, M., Murawski, A., and Pilz, T. 2014. Projections of regional changes in forest net primary productivity for different tree species in Europe driven by climate change and carbon dioxide. Ann. For. Sci. 71(2): 211-225. doi:10.1007/s13595-013-0306-8.

Riahi, K., Rao, S., Krey, V., Cho, C., Chirkov, V., Fischer, G., Kindermann, G., Nakicenovic, N., and Rafaj, P. 2011. RCP 8.5-A scenario of comparatively high greenhouse gas emissions. Clim. Change 109(1): 33-57. doi:10.1007/s10584-011$0149-\mathrm{y}$.

Shuttleworth, W.J., and Wallace, J.S. 1985. Evaporation from sparse crops-an energy combination theory. Q. J. R. Meteorol. Soc. 111(469): 839-855. doi:10.1002/qj.49711146910.

Singer, A., Johst, K., Banitz, T., Fowler, M.S., Groeneveld, J., Guti??rrez, A.G., Hartig, F., Krug, R.M., Liess, M., Matlack, G., Meyer, K.M., Pe'er, G., Radchuk, V., Voinopol-Sassu, A.J., and Travis, J.M.J. 2016. Community dynamics under environmental change: How can next generation mechanistic models improve projections of species distributions? Ecol. Modell. 326: 63-74. Elsevier B.V. doi:10.1016/j.ecolmodel.2015.11.007.

Sitch, S., Huntingford, C., Gedney, N., Levy, P.E., Lomas, M., Piao, S.L., Betts, R., Ciais, P., Cox, P., Friedlingstein, P., Jones, C.D., Prentice, I.C., and Woodward, F.I. 2008. Evaluation of the terrestrial carbon cycle, future plant geography and climatecarbon cycle feedbacks using five Dynamic Global Vegetation Models (DGVMs). Glob. Chang. Biol. 14(9): 2015-2039. doi:10.1111/j.1365-2486.2008.01626.x. 
Smith, W.B., Miles, P.D., Perry, C.H., and Pugh, S.A. 2009. Forest Resources of the United States, 2007. Gen Tech. Rep. WO-78. Washington, DC.

Solomon, A. 1986. Transient response of forests to CO2-induced climate change: simulation modeling experiments in eastern North America. Oecologia 68(4): 567579. Available from http://link.springer.com/article/10.1007/BF00378773 [accessed 14 April 2014].

Staff, S.S. (n.d.). Soil Survey Geographic (SSURGO) Database. Available from http://websoilsurvey.nrcs.usda.gov/ [accessed 10 January 2015].

Taft, J.B. 1997. Savanna and Open-Woodland Communities. In Conservation in Highly Fragmented Landscapes. Springer New York, Boston, MA. pp. 24-54. doi:10.1007/978-1-4757-0656-7_2.

Taylor, K.E., Stouffer, R.J., and Meehl, G. a. 2012. An overview of CMIP5 and the experiment design. Bull. Am. Meteorol. Soc. 93(4): 485-498. doi:10.1175/BAMSD-11-00094.1.

Team, R.C. 2016. R: A language and environment for statistical computing. R Foundation for Statistical Computing, Vienna, Austria. Available from https://www.r-project.org/.

Urban, D., Harmon, M., and Halpern, C. 1993. Potential response of Pacific Northwestern forests to climatic change, effects of stand age and initial composition. Clim. Change 23(3): 247-266. Available from http://www.springerlink.com/index/X363500010500635.pdf [accessed 3 October 
Vanderwel, M.C., and Purves, D.W. 2014. How do disturbances and environmental heterogeneity affect the pace of forest distribution shifts under climate change? Ecography (Cop.). 37(1): 10-20. doi:10.1111/j.1600-0587.2013.00345.x.

Weiskittel, A.R., Crookston, N.L., and Radtke, P.J. 2011. Linking climate, gross primary productivity, and site index across forests of the western United States. Can. J. For. Res. 41(8): 1710-1721. doi:10.1139/x11-086.

Wullschleger, S., Gunderson, C., Tharp, M.L., West, D., and Post, W.M. 2003. Simulated patterns of forest succession and productivity as a consequence of altered precipitation. In North American temperate deciduous forest responses to changing precipitation regimes. Edited by P. Hanson and S. Wullschleger. Springer, New York, New York, USA. pp. 433-446.

Wullschleger, S., Jackson, R., Currie, W., Friend, A., Luo, Y., Mouillot, F., Pan, Y., and Shao, G. 2001. Below-ground processes in gap models for simulating forest response to global change. Clim. Change 51(3-4): 449-473. Available from http://link.springer.com/article/10.1023/A:1012570821241 [accessed 15 April 2014]. 
Table 1. List of climate and soil variables used in regression tree analysis.

Climate variables

FD - Number of frost days

SU - Number of summer days

GSL - Growing season length

R10MM - Annual count of days where

precipitation is $>10 \mathrm{~mm}$

R20MM - Annual count of days where

precipitation is $>20 \mathrm{~mm}$

RX5DAY - Monthly maximum

consecutive 5-day precipitation

SDII - Simple precipitation intensity

index

DROUGHTLEN - Number of

consecutive days with less than $5 \mathrm{~mm}$ of

precipitation
Soil variables

DEPTH - Depth of soil

STONEF - Percent stone

PSIF - Matric potential at field capacity

THETAWP - Water content at wilting

point

THETAF - Water content at field

capacity

THETASAT - Water content at saturation

BEXP - Exponent for relationship

between matric potential and water

content

$\mathrm{KF}-$ Hydraulic conductivity at field

capacity 


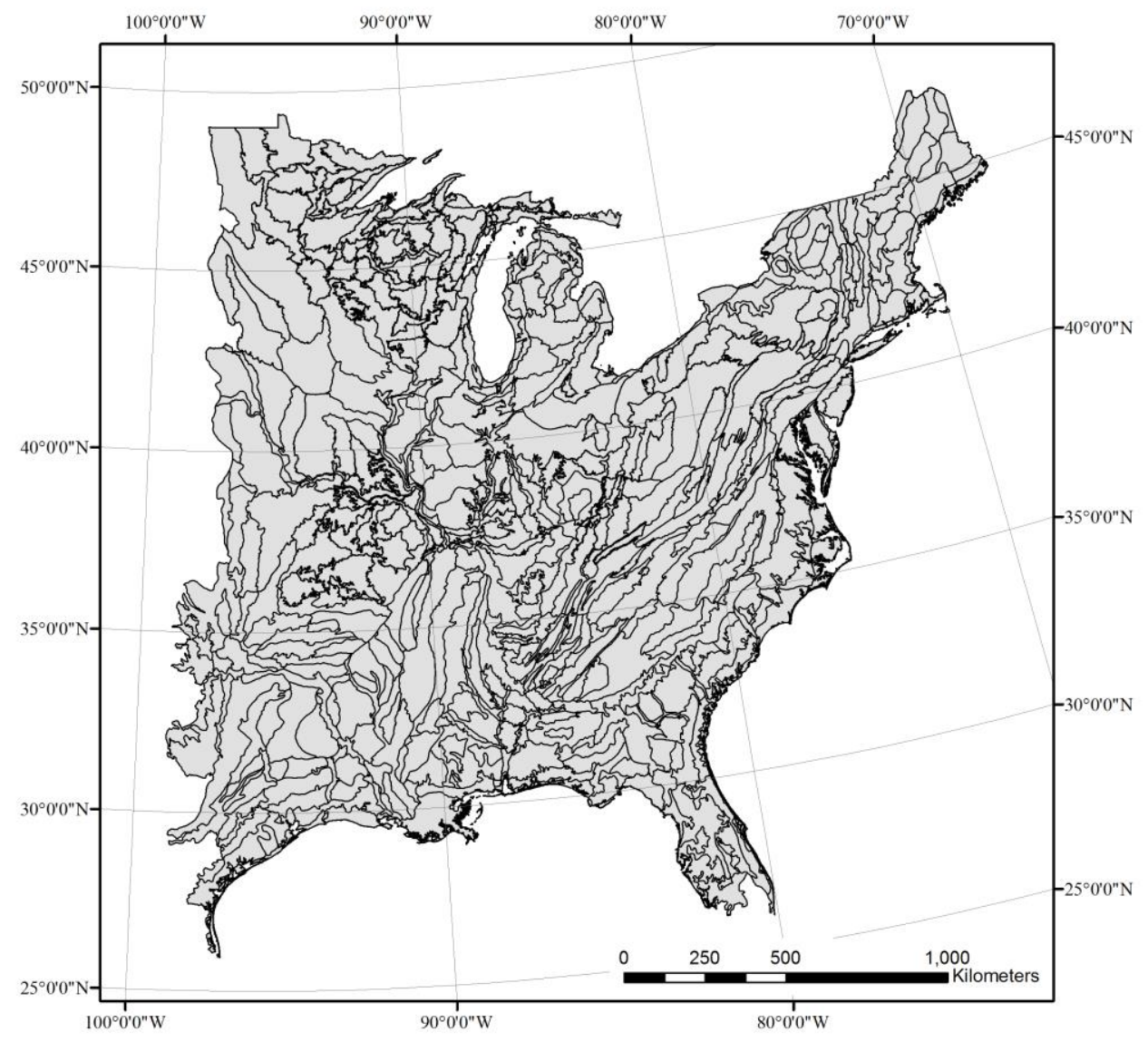

Figure 1. Map of ecological subsections of the Eastern United States. 


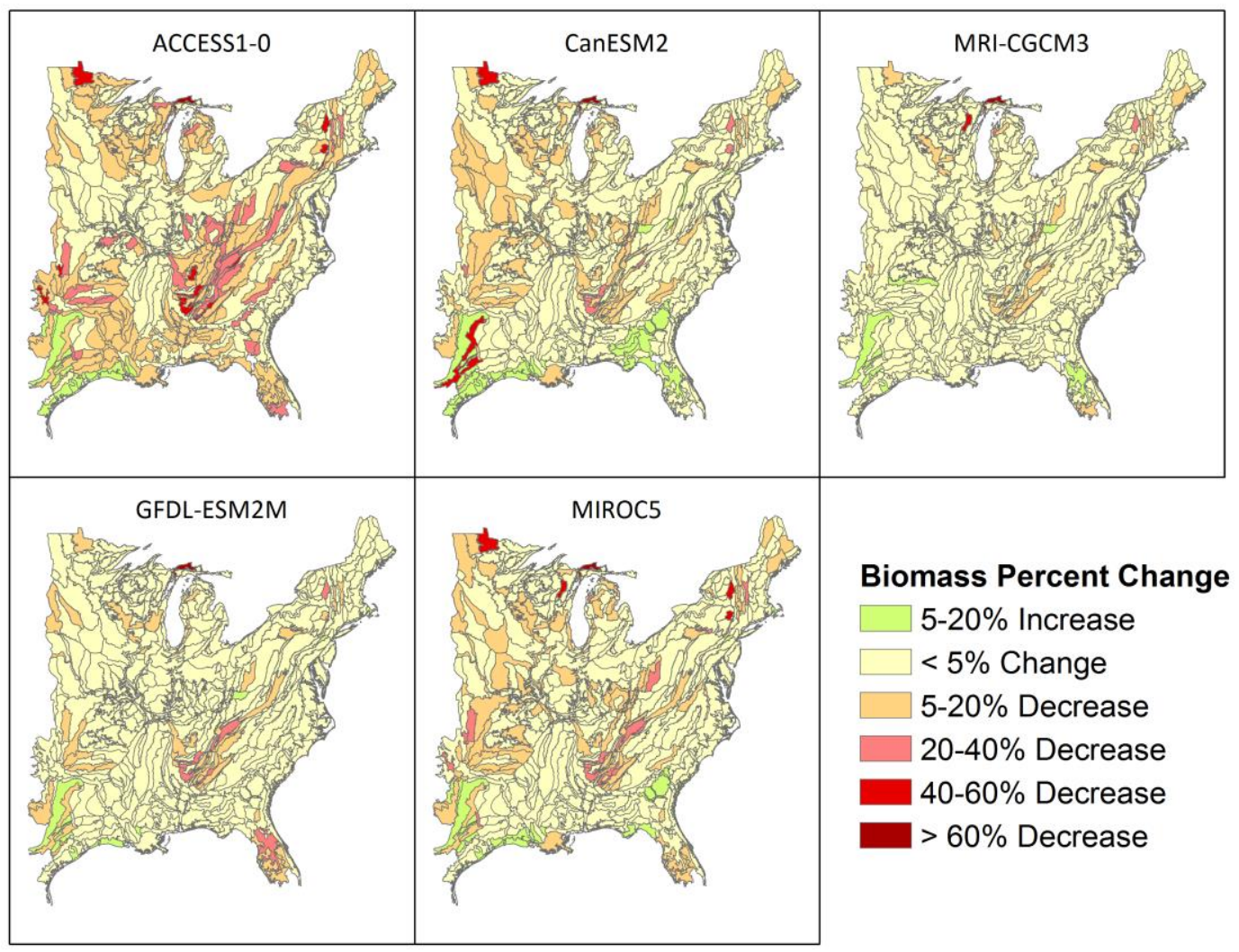

Figure 2. Percent change in mean total biomass under five GCMs compared to current climate by ecological subsection. 

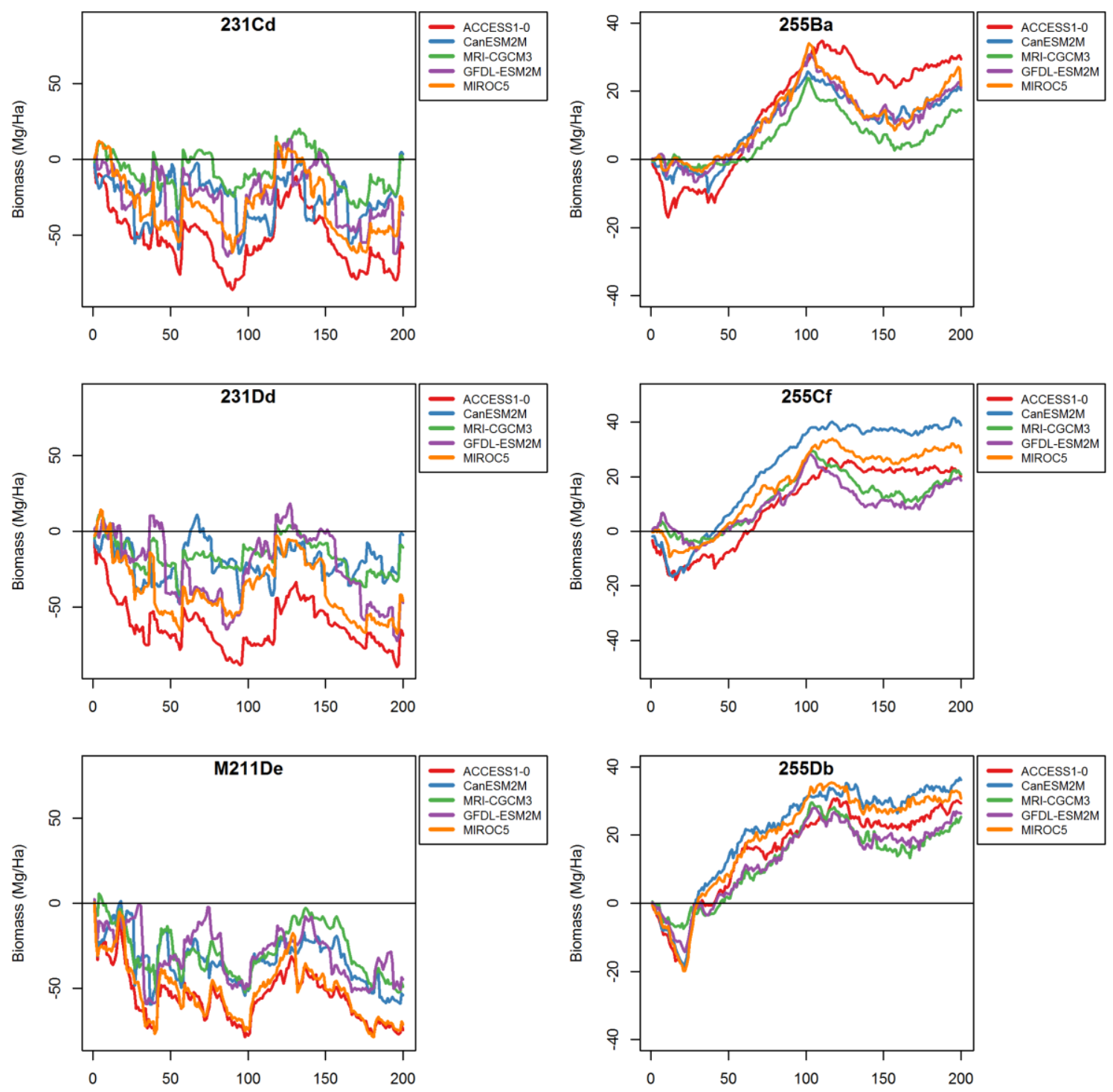

Figure 3. Trajectories of absolute change in total biomass under five GCMs compared to current climate in six selected ecological subsections over 200 simulation years. 


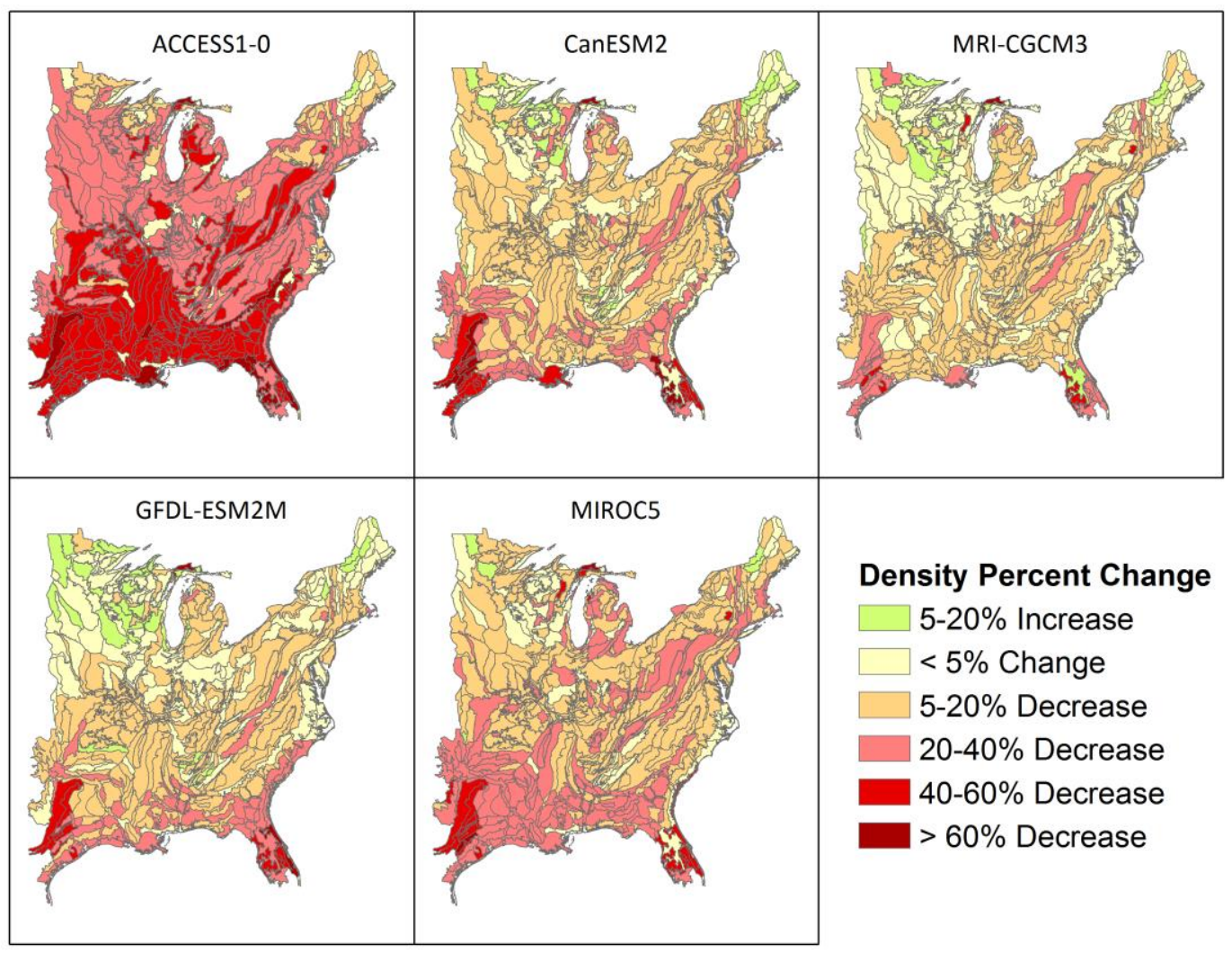

Figure 4. Percent change in mean total stems under five GCMs compared to current climate by ecological subsection. 


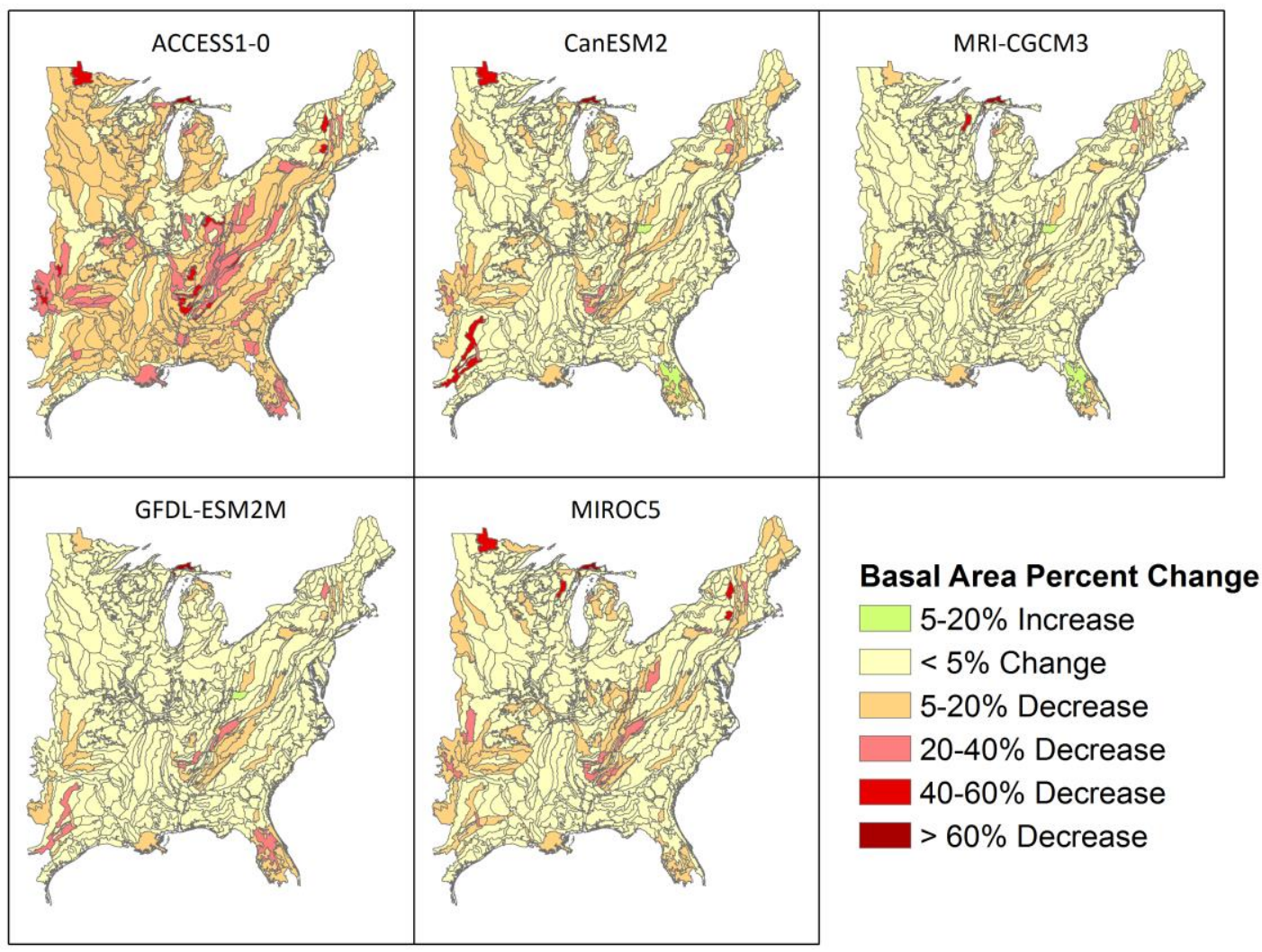

Figure 5. Percent change in mean total basal area when compared to results under the current climate for five GCMs by ecological subsection. 


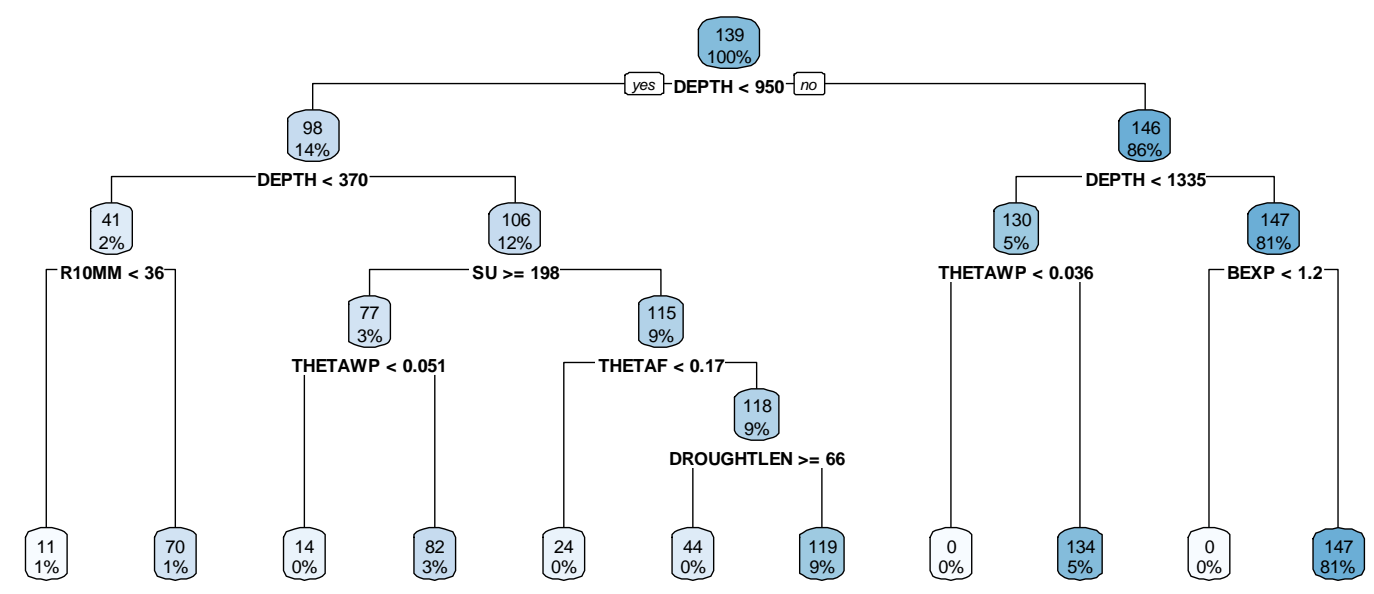

Figure 6. Regression tree analysis of maximum total aboveground biomass predicted by LINKAGES 3.0. Each node is labeled with the mean biomass and percentage of observations within the group. The explanatory variable and split value are shown below each node. 


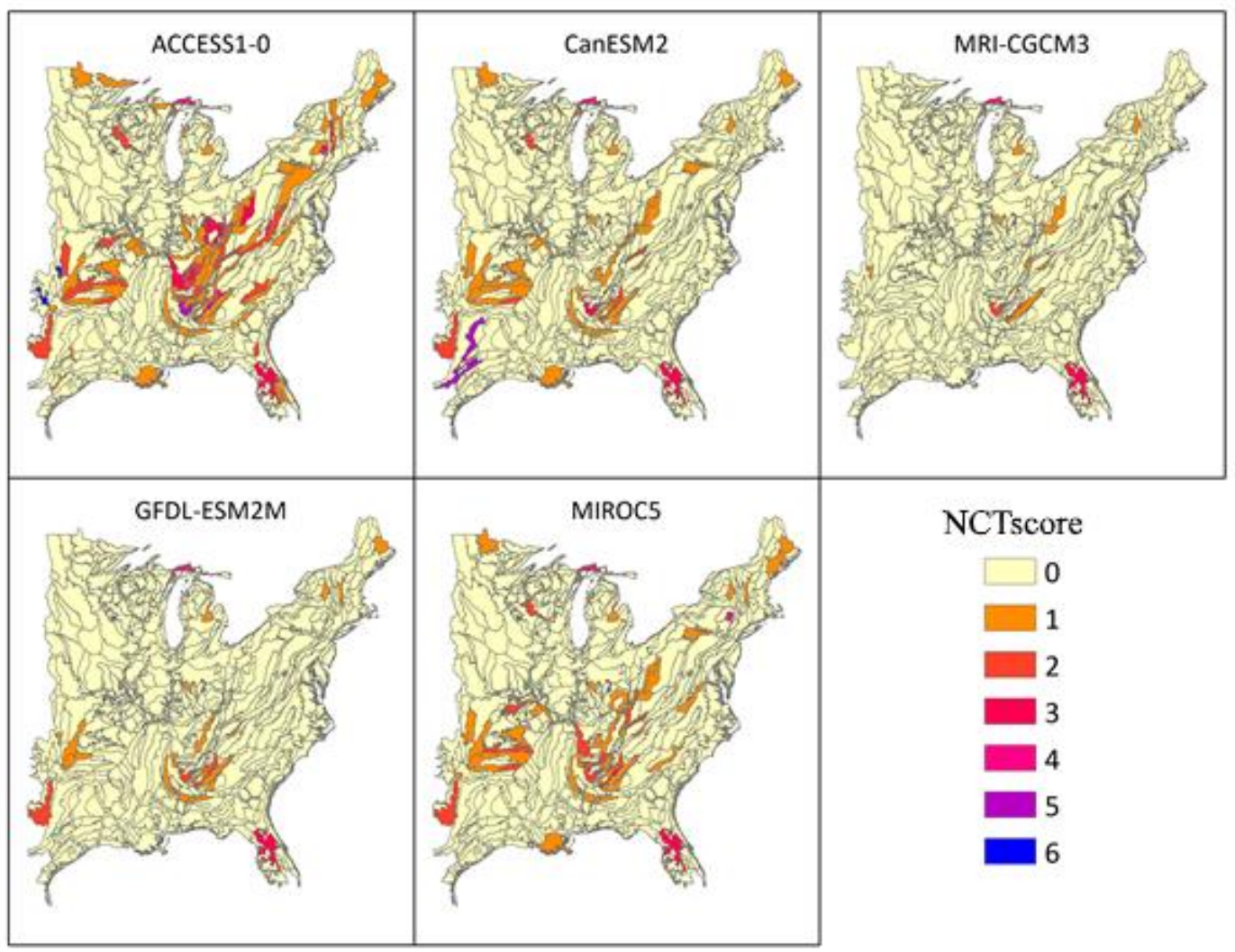

Figure 7. Natural community type transition score (NCTscore) for five GCMs by ecological subsection. Each subsection was modeled using five different soils with 100 replications each. Plots that transitioned from forest to woodland or woodland to savanna were assigned an NCTscore of one. Plots that transitioned from forest to savanna were assigned an NCTscore of two. The sum of NCTscore across five plots is shown for each subsection. 


\section{CHAPTER 3}

\section{A PROBABILITY BASED METHOD TO ESTIMATE FIRE DISTURBANCE MORTALITY WITHIN A FOREST LANDSCAPE MODEL}

\section{INTRODUCTION}

Fire is an important component in determining ecosystem trajectories and transitions across forested landscapes. The frequency, intensity, and absence of fire can determine species composition and stand structure at varying spatial scales (Iverson et al. 2008a; Sturtevant et al. 2009b; Knapp et al. 2017). The use of fire as a management tool is increasing as managers look for new tactics to increase forest resilience, restore desirable historical conditions, or control invasive species (Brown et al. 2004; Mitchell et al. 2006, 2014; Millar et al. 2007; Buma and Wessman 2011; Knapp et al. 2015).

Researchers often employ models to study the effects of fire as a management tool or stochastic natural process under novel conditions, long temporal scales, or large spatial scales (Keane et al. 1996; He and Mladenoff 1999b; Boulanger et al. 2017; Jin et al. 2018). Forest landscape models have been developed specifically to combine the interactions of spatial processes of fire disturbance, such as fire spread and ignition, with site-level fire effects. By combining these processes with those of stand dynamics, species dispersal, and other disturbance mechanisms researchers can use forest landscape models to examine the role that different fire regimes play across broad spatial and temporal scales that are not often feasible in direct field studies. 
In order for the results from forest landscape models to be useful, the underlying processes must produce realistic representations of complex ecological systems without adding unnecessary model complexity or processing time. LANDIS is a forest landscape model that has been developed to simulate site-level forest stand processes as well as spatially explicit disturbance and dispersal events across large landscapes (Mladenoff et al. 1996; He et al. 1999a; Scheller et al. 2007; Wang et al. 2013). Many of the components of succession and dispersal within LANDIS have been tested and validated over time (He and Mladenoff 1999a; He et al. 1999b; Wang et al. 2014, 2018; Xiao et al. 2016). Likewise, the spatial processes of modeling fire in LANDIS such as fire ignition and fire spread have been documented and tested (He and Mladenoff 1999a; Yang et al. 2008b; Sturtevant et al. 2009a; Luo et al. 2015). Previous versions of LANDIS (6.0 and earlier) used a presence/absence age cohort structure for tracking each species. This method was computationally efficient and could simulate forest landscape processes over large areas. One drawback to this design is that any species-level processes could only produce a binary response in individual cohorts. Fire tolerances are defined for species'age cohorts defined as percentage of the species' maximum longevity and if the tolerance of cohort is less than the severity of a fire on a pixel the entire cohort is removed (He and Mladenoff 1999b), which results in the complete removal of younger cohorts of all but the most fire tolerant species following even a low-intensity fire. Studies have shown that complete mortality is often not achieved within small-diameter classes, even among less fire tolerant species, following single or repeat low-intensity fires (Iverson et al. 2008a; Brose et al. 2013; Knapp et al. 2015; Kinkead et al. 2017). With development of LANDIS PRO version 7.0 the presence/absence age cohort structure of tracking species 
over the landscape was replaced with one that could directly track number of individual stems within each age cohort. This allows the model to simulate partial effects of system processes at the site-level and more realistically represent some stand dynamics (Fraser et al. 2013; Wang et al. 2015). The objectives of this study are: 1) Compare stem densities by size class on forest inventory plots to test the hypothesis that small diameter stem densities are reduced following low-intensity fires; 2) Compare the effectiveness of implementing a diameter-based probability of fire mortality against the previous agecohort removal method at reproducing post-fire stem densities within a forest landscape model; 3) Examine the effects on the landscape-level estimates of stem densities using the two fire mortality methods.

\section{METHODS}

\section{Study area}

I chose two different regions that represent different forest types and fire regimes. The Ozark Highlands ecological section (223A) is primarily located in southern Missouri and northern Arkansas. The forest cover types are largely composed of oak-hickory and oakpine forests (McNab et al. 2007). According to the most recent Forest Service inventory the most abundant trees by biomass volume in the region are Quercus alba (white oak), Quercus velutina (black oak), Quercus stellata (post oak), Quercus rubra (northern red oak), Pinus echinata (shortleaf pine), Quercus coccinea (scarlet oak), Juniperus virginiana (eastern redcedar), Carya tomentosa (mockernut hickory), Carya texana (black hickory), and Acer saccharum (sugar maple). 
The Gulf Coastal Plains and Flatwoods section (232B) is located mainly in the southern portions of Mississippi, Alabama, and Georgia while also covering parts of eastern Louisiana and northern Florida. The region is dominated by southern pine forest types with mixed hardwoods. Pinus taeda (loblolly pine) accounts for nearly $40 \%$ of biomass volume in the region while other common species include Quercus nigra (water oak), Liquidambar styraciflua (sweetgum), Pinus elliottii (slash pine), Quercus laurifolia (laurel oak), Liriodendron tulipifera (yellow-poplar), Quercus alba (white oak), Pinus palustris (longleaf pine), and Pinus echinata (shortleaf pine).

Fire is more frequent and on average of a higher severity in section 232B than in 223A (Eidenshink et al. 2007).

\section{Model parameterization}

LANDIS PRO is a grid-cell based spatially explicit forest landscape model that can simulate large landscapes over long temporal scales at a user-specified spatial resolution. By tracking stem density within age classes for individual species within each cell the model can simulate the processes of demography, stand dynamics, and disturbance. LANDIS PRO requires input parameters detailing species attributes, landtype attributes, forest composition, and disturbance characteristics.

Biological attributes for the 29 species were collected from previous studies and literature (Loehle 1988; Burns and Honkala 1990; Wang et al. 2015, 2016). The landtype map was created by aggregating the gridded SSURGO component map from 10 meters to 270 meters and intersecting the result with an ecological subsection layer. Individual landtype attributes such as species establishment probability and available growing space over 
time were created using the process described above. Initial forest composition was estimated using the software Landscape Builder (Dijak 2013). Using Forest Inventory and Analysis (FIA) (Woodall et al. 2010) data the Landscape Builder program assigns individual plot inventory information by stratifying the landscape using the landtypes derived from the landtype map and forest type which was estimated from 2011 National Land Cover Database (Homer et al. 2012). These two layers were intersected with FIA plot locations to create unique combinations of landtype and forest type which was then randomly populated with attributes of species composition, density, and sizes from plots within the most recent complete sampling cycle. Validation and calibration of the initial landscape and species parameters was performed using the methods outlined in Wang et al. (2014).

For this study I chose to model post-fire mortality using an equation based on studies using logistic regression to predict fire mortality using tree diameter at breast height (DBH) and height of charring on the stem (Regelbrugge and Smith 1994; Hély et al. 2003; Woolley et al. 2012). A review of post-fire mortality logistic regression models western North America found that DBH was the most frequent significant variable among the models reviewed (Woolley et al. 2012). Loomis (1973) conducted a study that sampled over 2,100 trees in oak-hickory forests and found that DBH and height of bole scorching were the most important variables in predicting post-fire mortality of trees smaller than 16 inches DBH. In a study of eastern mixed oak forests Regelbrugge and Smith (1994) found that DBH and height of bole scorching were effective explanatory variables for predicting the probability of top-killing following fire. The forest landscape model Fire-BGC uses a logistic regression based fire mortality function which includes 
bark thickness (calculated from species and DBH) and crown volume scorched (Keane et al. 2011).

The equation used in LANDIS PRO 7.0 to calculate probability of mortality following fire is as follows:

Equation 1

$$
\begin{aligned}
& \qquad P(m)=\left[1+e^{-\left(\beta_{0}+\beta_{1} X_{1}+\beta_{2} X_{2}\right)}\right]^{-1} \\
& \beta_{i}=\text { model coefficients } \\
& X_{1}=\text { tree diameter }(\mathrm{cm}) \text { at breast height } \\
& X_{2}=\text { height of bark charring }(\mathrm{m})
\end{aligned}
$$

The user provides five sets of model coefficients that correspond to the five fire tolerance classes for tree species. The $X_{2}$ parameter is used by the LANDIS PRO fire module analogously for fire severity. The user can set five values for $X_{2}$ that correspond to the five fire severity levels to produce a range of mortality probabilities for all combinations of species fire tolerances and fire severities.

I generated five sets of model coefficients that corresponded to the five fire tolerance classes that are part of species parameters within LANDIS PRO. The values for these parameters were estimated from previous studies in the regions (Regelbrugge and Smith 1994; Dey et al. 1996; Brose et al. 2013; Knapp et al. 2015; Kinkead et al. 2017) and further calibrated using FIA data from cycles 7 and 8 in sections 223A and 232B respectively. The model coefficients for each fire tolerance class were adjusted from initial values so that post-fire densities by diameter class more closely followed those 
found in FIA data. The fires in section 223A were parameterized to be low-intensity surface fires of severity 1 , while the fires in section 232B were either severity 1 or 2 (Eidenshink et al. 2007).

\section{Experimental design}

In order to examine the modeled post-fire effects on diameter distributions, a randomly generated landscape was modeled for each of the ecological sections in LANDIS PRO with 100 replications. Each replication was a 30 row and 30 column map composed of randomly selected pixels from the initial community map within the ecological section and regenerated for each replication. Pixels selected for section 223A represented FIA plots in cycle 8, while pixels selected for section 232B represent plots in cycle 9 (Woodall et al. 2010). Fire was applied to random pixels on the landscape using the LANDIS PRO fire module. The LANDIS PRO fire module was modified to simulate the original cohort-based mortality and the new diameter probability mortality and output stem densities by diameter classes for each method. For each replication the landscape was partitioned into unburned and burned cells and the tree densities for the eight diameter classes was extracted from each pixel. In addition, for each replication the frequency of pixels containing each diameter class was calculated.

The USDA Forest Service Forest Inventory and Analysis (FIA) (Woodall et al. 2010) was utilized to validate modeled mortality following fire. For each ecological section FIA plots that had a record of fire occurrence within the previous five years were identified. Trees within the plots were classified in to one of the eight diameter classes to match results from the LANDIS PRO output. Each diameter class was then summarized using the trees per acre expansion factor to produce density estimates from each plot. 


\section{Data analysis}

The Tukey Honest Significant Difference test was used to test pairwise differences in the mean stem density for each diameter category across the unburned, diameter probability fire mortality, and age-cohort fire mortality pixels. Welch's t-test was used to test differences in the mean stem density of each diameter category between landscapes simulated with diameter probability fire mortality and age-cohort fire mortality. To test for an effect of fire on the mean stem density by diameter class on FIA plots the Wilcox rank-sum test was used due to the large difference in sample size between burned and unburned plots.

\section{RESULTS}

\section{Forest inventory data}

The forest plots analyzed in section 223A $(n=2039)$ showed that mean densities of the smallest diameter class and the 5-10 cm class were significantly lower in the burned plots. The mean densities in the $10-15 \mathrm{~cm}$ class was also lower in burned plots, although not statistically significant (Table ). The mean densities for all other diameter classes were within 5 trees per acre (Figure 2). This is consistent with results found in literature where stem density following low-intensity fire was studied. Brose et al. (2013) found in a meta-analysis that mortality following a single fire in oak dominated forests mainly restricted to saplings less than $10 \mathrm{~cm} \mathrm{DBH,} \mathrm{while} \mathrm{larger} \mathrm{size} \mathrm{classes} \mathrm{were} \mathrm{less} \mathrm{likely} \mathrm{to} \mathrm{be}$ affected. Knapp et al. (2015) found a decline in mid-story sapling (3 - $10 \mathrm{~cm} \mathrm{DBH)}$ density following periodic burns on plots located within ecological section 223A. 
Kinkead et al. (2017) found that mortality following burning was composed mostly of saplings $<=11 \mathrm{~cm} \mathrm{DBH}$ on plots also located in section 223A.

The forest plots in section 232B $(n=4867)$ had lower mean stem densities on burned plots in the $<=5 \mathrm{~cm}, 5-10 \mathrm{~cm}$, and $10-15 \mathrm{~cm}$ diameter classes while the stem densities in the $25-30 \mathrm{~cm}, 30-35 \mathrm{~cm}$, and $>35 \mathrm{~cm}$ classes were higher on burned plots (Table 2, Figure 3). Hodgkins (1958) found that fire in southern pine forests significantly reduced understory stem densities in saplings $10 \mathrm{~cm}$ DBH or less. Waldrop and Lloyd (1988) found that prescribed fires in loblolly pine stands significantly reduced stem densities, with much of the mortality occurring in smaller diameter classes. Likewise, McNab (1977) found that low-intensity fires reduced stem densities in loblolly pine stands and that mortality was limited to trees $10 \mathrm{~cm} \mathrm{DBH}$ and smaller.

\section{Simulated landscape}

Simulations for landscapes populated with plots from section 223A had a mean decrease of about 50 trees per acre in the $<=5 \mathrm{~cm}$ diameter class on burned pixels using the diameter-based probability mortality (Table 3). All other size classes were unchanged. Using the cohort-based mortality function the stem density for all size classes was significantly lower which is likely due to the less fire-tolerant species composition in the region (Figure 4). Half of the top 10 most abundant species in the region; black oak, scarlet oak, northern red oak, sugar maple, and mockernut hickory, have a fire tolerance rating in the model of two or less, meaning they are moderately to very intolerant of fire. Even the lowest intensity fire would kill $50 \%$ to $85 \%$ of age cohorts in these species using the age-cohort based mortality method. For example, black oak has a fire tolerance rating of two and a longevity of 150 years. In a low severity fire, using the earlier cohort- 
based mortality design, age classes up to $50 \%$ of the maximum longevity would be removed which corresponds to black oak individuals from $1-70$ years of age. The results from diameter-based probability pixels correspond well to the results found in FIA data where only the smallest diameter classes were effected by fire while the cohortbased mortality had decreases in all diameter classes.

In section $232 \mathrm{~B}$ the $<=5 \mathrm{~cm}$ and $5-10 \mathrm{~cm}$ diameter classes decreased in stem density by approximately $50 \%$ in pixels burned with the diameter-based probability mortality function while age-cohort based burned pixels decreased by $90 \%$ and $50 \%$ respectively (Table 4). The 10-15 cm and 15-20 cm diameter classes had small, but significant decreases in stem densities under the diameter-based burn while the age-cohort based burns had larger declines. There was no effect of fire for all larger diameter classes under the diameter-based burns when compared to unburned pixels while the age-cohort burned was significantly lower in the $20-25 \mathrm{~cm}$ diameter class and had no effect in all larger diameter classes (Figure 5). This region is predominantly composed of loblolly pine which is parameterized in the model with a fire tolerance rating of four. This means that with a fire severity of two on the landscape, only loblolly pine individuals from age 1-40 would be removed under age-cohort based mortality while under the diameter-based mortality probability trees at $2 \mathrm{~cm}$ have a $60 \%$ change of being killed which declines to $1 \%$ at $12 \mathrm{~cm}$.

At the landscape scale, in section 223A the cohort-based mortality had lower frequency of all diameter classes except the $>35 \mathrm{~cm}$ class (Table 5). In section 232B the diameter classes $<=5,10-15,15-20,20-25$, and $25-30 \mathrm{~cm}$ all had lower mean frequencies using the age-cohort mortality (Table 6). If aggregated across a larger landscape the effects on 
overall forest structure may be diminished, especially if fire is less frequent, although if species composition were examined there would likely be more significant differences between landscapes using the two different methods of estimating fire mortality.

\section{DISCUSSION}

After analyzing over 6,900 forest inventory plots distributed over two ecological sections I showed that plots that had recently burned had significantly lower number of individuals in smaller diameter classes when compared to unburned plots. By parameterizing and calibrating the LANDIS PRO forest landscape model using independent plot data I was able to realistically reproduce this response within the model.

The residual small-diameter stems in stands that experience a low-intensity fire are an important component along with regeneration in determining the species composition and structure of the understory in the following years, particularly in plots that do not experience repeat fires (Hodgkins 1958; Dey and Hartman 2005; Iverson et al. 2008a;

Brose et al. 2013). In a study conducted in mixed pine-hardwood forests of the southern Appalachians following a single fire of three different intensities there were few species where stems less than $5 \mathrm{~cm}$ were completely removed (Elliott et al. 1999), even under the highest observed fire intensity. In oak-hickory forests following a single prescribed burn Kinkead et al. (2017) found that mortality rates for trees less than $11 \mathrm{~cm} \mathrm{DBH}$ ranged from $16 \%$ to $56 \%$ while Dey and Hartman (2005) found that no species had a complete removal of seedlings and saplings following a single burn. These results present an argument for a more sophistical approach to modeling fire effects within forest landscape models. Incorporating a probability-based method for modeling first-order fire effects 
which takes advantage of increased tree-level information (DBH) within LANDIS PRO without adding processing time or sacrificing spatial and temporal resolution. A more accurate representation of first-order fire effects can translate to improved modeling of second-order fire effects which are often more useful to managers or planners (Reinhardt et al. 2001).

In many studies these second-order fire effects, particularly the effect of fire on forest succession, are aggregated to the landscape-scale in order to estimate the impact of novel fire regimes or other management strategies. While the output from forest landscape models is spatially explicit results are often presented as an average proportion of the landscape occupied by individual species, forest types, size classes, or age classes (He and Mladenoff 1999b; Scheller et al. 2005; Shang et al. 2007). In this study I showed that modeling fire effects using a more empirically-based method can have an effect on measurements of landscape proportions with the presence of individual size classes.

The results presented here represent only the effects of fire and residual stem densities following a fire event and do not include resprouting or seed regeneration which occur during a later process in LANDIS PRO. It is possible for stems regenerating following fire to grow vigorously enough to reach 1.0 inch DBH within five years in order to be included in FIA plot inventories, however these are difficult to identify from the data so stem densities simulated from LANDIS PRO following fire were not directly compared to FIA estimates. The significant difference in size classes among FIA plots that were burned compared to those unburned highlights the utility of this database as a resource for parameterizing and calibrating forest landscape models and fire effect models. 


\section{CONCLUSION}

I described an empirical modeling approach to fire mortality and showed that this method can realistically represent decreases in stem densities across diameter classes following low-intensity fires that are observed in field studies and inventory data. I found support for my hypothesis that small-diameter stem densities should be lower on plots that experienced fire in the previous five years. I implemented an empirically-based fire mortality probability model in order to more realistically model first-order fire effects within LANDIS PRO and showed that estimates of post-fire stem densities across size classes closely followed those found in forest inventory data and previous studies. By comparing results of my new probability-based mortality method in LANDIS PRO to the previous age-based method across two test landscapes I showed that the method of modeling fire effects can significantly affect estimations of the presence of certain forest size classes at the landscape-scale. 


\section{LITERATURE CITED}

Boulanger, Y., Taylor, A.R., Price, D.T., Cyr, D., and Sainte-Marie, G. 2017. Stand-level drivers most important in determining boreal forest response to climate change. $\mathrm{J}$. Ecol. (October 2017). doi:10.1111/1365-2745.12892.

Brose, P.H., Dey, D.C., Phillips, R.J., and Waldrop, T.A. 2013. A meta-analysis of the fire-oak hypothesis: Does prescribed burning promote oak reproduction in Eastern North America? For. Sci. 59(3): 322-334. doi:10.5849/forsci.12-039.

Brown, R.T., Agee, J.K., and Franklin, J.F. 2004, August 1. Forest restoration and fire: Principles in the context of place. Wiley/Blackwell (10.1111). doi:10.1111/j.15231739.2004.521_1.x.

Buma, B., and Wessman, C.A. 2011. Disturbance interactions can impact resilience mechanisms of forests. Ecosphere 2(5). doi:10.1890/ES11-00038.1.

Burns, R.M., and Honkala, B.H. 1990. Silvics of North America: Volume 2: Hardwoods. In Agriculture Handbook 654.

Dey, D.C., and Hartman, G. 2005. Returning Fire to Ozark Highland Forest Ecosystems: Effects on Advance Regeneration. For. Ecol. Manage. 217: 37-53.

Dey, D.C., Johnson, P.S., and Garrett, H.E. 1996. Modeling the regeneration of oak stands in the Missouri Ozark Highlands. Can. J. For. Res. 26(4): 573-583. doi:10.1139/x26-066.

Dijak, W. 2013. Landscape Builder: Software for the creation of initial landscapes for LANDIS from FIA data. Comput. Ecol. Softw. 3(2): 17-25. doi:10.0000/issn-2220- 
721x-compuecol-2013-v3-0003.

Eidenshink, J., Schwind, B., Brewer, K., Zhu, Z., Quayle, B., and Howard, S. 2007. A Project for Monitoring Trends in Burn Severity. Fire Ecol. 3(1): 3-21. doi:10.4996/fireecology.0301003.

Elliott, K.J., L. Hendrick, R., Major, A.E., Vose, J.M., and Swank, W.T. 1999. Vegetation dynamics after a prescribed fire in the southern Appalachians. For. Ecol. Manage. 114(2-3): 199-213. doi:10.1016/S0378-1127(98)00351-X.

Fraser, J.S., He, H.S., Shifley, S.R., Wang, W.J., and Thompson, F.R. 2013. Simulating stand-level harvest prescriptions across landscapes: LANDIS PRO harvest module design. Can. J. For. Res. 43(10): 972-978. NRC Research Press. doi:10.1139/cjfr2013-0190.

He, H., and Mladenoff, D. 1999a. The effects of seed dispersal on the simulation of longterm forest landscape change. Ecosystems 2(4): 308-319. doi: $10.1007 \% 2 \mathrm{Fs} 100219900082$.

He, H.S., and Mladenoff, D.J. 1999b. Spatially explicit and stochastic simulation of forest-landscape fire disturbance and succession. Ecology 80(1): 81-99. doi:10.2307\%2F176981.

He, H.S., Mladenoff, D.J., and Boeder, J. 1999a. An object-oriented forest landscape model and its representation of tree species. Ecol. Modell. 119(1): 1-19. Available from http://www.scopus.com/inward/record.url?eid=2-s2.00033168602\&partnerID=40\&md5=6e97c56f1 f9f8987a4731051652c8422. 
He, H.S., Mladenoff, D.J., and Crow, T.R. 1999b. Linking an ecosystem model and a landscape model to study forest species response to climate warming. Ecol. Modell. 114(2-3): 213-233. Available from http://www.scopus.com/inward/record.url?eid=2-s2.00032928948\&partnerID=40\&md5=f5d3ed7596ff7bfa28ead2eb492f68cc.

Hély, C., Flannigan, M., and Bergeron, Y. 2003. Modeling tree mortality following wildfire in the southeastern Canadian mixed-wood boreal forest. For. Sci. 49(4): 566-576. Available from http://www.ingentaconnect.com/content/saf/fs/2003/00000049/00000004/art00008 [accessed 17 April 2014].

Hodgkins, E.J. 1958. Effects of Fire on Undergrowth Vegetation in Upland Southern Pine Forests. Ecology 39(1): 36. doi:10.2307/1929965.

Homer, C., Fry, J., and Barnes, C.A. 2012. The National Land Cover Database. US Geol. Surv. Fact Sheet (February): 1-4. Available from http://pubs.usgs.gov/fs/2012/3020/.

Iverson, L.R., Hutchinson, T.F., Prasad, A.M., and Peters, M.P. 2008. Thinning, fire, and oak regeneration across a heterogeneous landscape in the eastern U.S.: 7-year results. For. Ecol. Manage. 255(7): 3035-3050. Elsevier. doi:10.1016/j.foreco.2007.09.088.

Jin, W., He, H.S., Shifley, S.R., Wang, W.J., Kabrick, J.M., and Davidson, B.K. 2018. How can prescribed burning and harvesting restore shortleaf pine-oak woodland at the landscape scale in central United States? Modeling joint effects of harvest and 
fire regimes. For. Ecol. Manage. 410: 201-210. doi:10.1016/j.foreco.2017.07.040.

Keane, R., Loehman, R., and Holsinger, L. 2011. The FireBGCv2 Landscape Fire Succession Model: a research simulation platform for exploring fire and vegetation dynamics. U.S. Department of Agriculture, Forest Service, Rocky Mountain Research Station, Fort Collins, CO. Available from http://treesearch.fs.fed.us/pubs/37464 [accessed 13 March 2014].

Keane, R.E., Ryan, K.C., and Running, S.W. 1996. Simulating effects of fire on northern Rocky Mountain landscapes with the ecological process model FIRE-BGC. Tree Physiol. 16(3): 319-31. Available from http://www.ncbi.nlm.nih.gov/pubmed/14871733.

Kinkead, C.S., Stambaugh, M.C., and Kabrick, J.M. 2017. Mortality, scarring, and growth in an oak woodland following prescribed fire and commercial thinning in the Ozark Highlands. For. Ecol. Manage. 403: 12-26. Elsevier B.V. doi:10.1016/j.foreco.2017.07.028.

Knapp, B.O., Hullinger, M.A., and Kabrick, J.M. 2017. Effects of fire frequency on longterm development of an oak-hickory forest in Missouri, U.S.A. For. Ecol. Manage. 387: 19-29. Elsevier B.V. doi:10.1016/j.foreco.2016.07.013.

Knapp, B.O., Stephan, K., and Hubbart, J.A. 2015. Structure and composition of an oakhickory forest after over 60 years of repeated prescribed burning in Missouri, U.S.A. For. Ecol. Manage. 344: 95-109. doi:10.1016/j.foreco.2015.02.009.

Loehle, C. 1988. Tree life history strategies: the role of defenses. Can. J. For. Res. 18(2): 
209-222. doi:10.1139/x88-032.

Loomis, R.M. 1973. Estimating fire-caused mortality and injury in oak-hickory forests. U.S. Dept. of Agriculture, Forest Service, North Central Forest Experiment Station, St. Paul, MN.

Luo, X., He, H.S., Liang, Y., and Wu, Z. 2015. Evaluating simulated effects of succession, fire, and harvest for LANDIS PRO forest landscape model. Ecol. Modell. 297: 1-10. Elsevier B.V. doi:10.1016/j.ecolmodel.2014.10.040.

McNab, W.H. 1977. An Overcrowded Loblolly Pine Stand Thinned With Fire. South. J. Appl. For. 1(1): 24-26. Oxford University Press. doi:10.1093/sjaf/1.1.24.

McNab, W.H., Cleland, D.T., Freeouf, J.A., Keys, Jr., J.E., Nowacki, G.J., and Carpenter, C.A. 2007. Description of ecological subregions: sections of the conterminous United States. In Gen. Tech. Report WO-76B. U.S. Department of Agriculture, Forest Service, Washington, DC.

Millar, C.I., Stephenson, N.L., and Stephens, S.L. 2007. Climate change and forest of the future: Managing in the face of uncertanity. Ecol. Appl. 17(8): 2145-2151. doi:http://dx.doi.org/10.1890/06-1715.1.

Mitchell, R.J., Hiers, J.K., O’Brien, J.J., Jack, S.B., and Engstrom, R.T. 2006. Silviculture that sustains: the nexus between silviculture, frequent prescribed fire, and conservation of biodiversity in longleaf pine forests of the southeastern United States. Can. J. For. Res. 36(11): 2724-2736. doi:10.1139/x06-100.

Mitchell, R.J., Liu, Y., O’Brien, J.J., Elliott, K.J., Starr, G., Miniat, C.F., and Hiers, J.K. 
2014. Future climate and fire interactions in the southeastern region of the United States. For. Ecol. Manage. 327: 316-326. Elsevier. doi:10.1016/J.FORECO.2013.12.003.

Mladenoff, D.J., Host, G.E., Boeder, J., and Crow, T.R. 1996. LANDIS: a spatial model of forest landscape disturbance, succession, and management. In GIS and environmental modeling: progress and research issues. Edited by M.F. Goodchild, L.T. Steyaert, B.O. Parks, C. Johnston, D. Maidment, M. Crane, and S. Glendinning. John Wiley \& Sons, New York. pp. 175-180.

Regelbrugge, J.C., and Smith, D.W. 1994. Postfire Tree Mortality in Relation to Wildfire Severity in Mixed Oak Forests in the Blue Ridge of Virginia. North. J. Appl. For. 11(3): 90-97. Available from http://www.ingentaconnect.com/content/saf/njaf/1994/00000011/00000003/art00006

Reinhardt, E.D., Keane, R.E., and Brown, J.K. 2001. Modeling fire effects. Int. J. Wildl. Fire 10(4): 373-380. doi:http://dx.doi.org/10.1071/WF01035.

Scheller, R.M., Domingo, J.B., Sturtevant, B.R., Williams, J.S., Rudy, A., Gustafson, E.J., and Mladenoff, D.J. 2007. Design, development, and application of LANDISII, a spatial landscape simulation model with flexible temporal and spatial resolution. Ecol. Modell. 201(3-4): 409-419. Available from http://www.scopus.com/inward/record.url?eid=2-s2.033846692695\&partnerID=40\&md5=234e06ef81388ae7cae4fbdbb3344e 81 .

Scheller, R.M., Mladenoff, D.J., Crow, T.R., and Sickley, T. a. 2005. Simulating the 
Effects of Fire Reintroduction Versus Continued Fire Absence on Forest Composition and Landscape Structure in the Boundary Waters Canoe Area, Northern Minnesota, USA. Ecosystems 8(4): 396-411. doi:10.1007/s10021-003$0087-2$.

Shang, Z.B., He, H.S., Lytle, D.E., Shifley, S.R., and Crow, T.R. 2007. Modeling the long-term effects of fire suppression on central hardwood forests in Missouri Ozarks, using LANDIS. For. Ecol. Manage. 242: 776-790.

Sturtevant, B.R., Miranda, B.R., Yang, J., He, H.S., Gustafson, E.J., and Scheller, R.M. 2009a. Studying fire mitigation strategies in multi-ownership landscapes: Balancing the management of fire-dependent ecosystems and fire risk. Ecosystems 12(3): 445461. Available from http://www.scopus.com/inward/record.url?eid=2-s2.063149183127\&partnerID=40\&md5=3149bd11865fc818a0817272e31605d7.

Sturtevant, B.R., Scheller, R.M., Miranda, B.R., Shinneman, D., and Syphard, A. 2009b. Simulating dynamic and mixed-severity fire regimes: A process-based fire extension for LANDIS-II. Ecol. Modell. 220(23): 3380-3393. doi:10.1016/j.ecolmode1.2009.07.030.

Waldrop, T.A., and Lloyd, F.T. 1988. Precommercial Thinning a Sapling-Sized Loblolly Pine Stand with Fire. South. J. Appl. For. 12(3): 203-207. Oxford University Press. doi:10.1093/sjaf/12.3.203.

Wang, W.J., He, H.S., Spetich, M.A., Shifley, S.R., Thompson, F.R., Dijak, W.D., and Wang, Q. 2014. A framework for evaluating forest landscape model predictions using empirical data and knowledge. Environ. Model. Softw. 62: 230-239. 
doi:10.1016/j.envsoft.2014.09.003.

Wang, W.J., He, H.S., Spetich, M.A., Shifley, S.R., Thompson III, F.R., Larsen, D.R., Fraser, J.S., and Yang, J. 2013. A large-scale forest landscape model incorporating multi-scale processes and utilizing forest inventory data. Ecosphere 4(9): 1-22. doi:10.1890/ES13-00040.1.

Wang, W.J., He, H.S., Thompson, F.R., Spetich, M.A., and Fraser, J.S. 2018. Effects of species biological traits and environmental heterogeneity on simulated tree species distribution shifts under climate change. Sci. Total Environ. 634: 1214-1221. Elsevier B.V. doi:10.1016/j.scitotenv.2018.03.353.

Wang, W.J., He, H.S., Thompson III, F.R., Fraser, J.S., and Dijak, W.D. 2016. Changes in forest biomass and tree species distribution under climate change in the northeastern United States. Landsc. Ecol. Springer Netherlands. doi:10.1007/s10980-016-0429-z.

Wang, W.J., He, H.S., Thompson III, F.R., Fraser, J.S., Hanberry, B.B., and Dijak, W.D. 2015. The importance of succession, harvest, and climate change in determining future forest composition changes of the U.S. Central Hardwood Forests. Ecosphere 6(12): art277. doi:10.1890/ES15-00238.1.

Woodall, C., Conkling, B., Amacher, M., Coulston, J., Jovan, S., Perry, C., Schulz, B., Smith, G., and Will Wolf, S. 2010. The forest inventory and analysis database version 4.0: database description and users manual for phase 3. Newtown Square, PA. Available from http://www.treesearch.fs.fed.us/pubs/35009 [accessed 1 October 2012]. 
Woolley, T., Shaw, D.C., Ganio, L.M., and Fitzgerald, S. 2012. A review of logistic regression models used to predict post-fire tree mortality of western North American conifers. Int. J. Wildl. Fire 21(1): 1. doi:10.1071/WF09039.

Xiao, J., Liang, Y., He, H.S., Thompson, J.R., Wang, W.J., Fraser, J.S., and Wu, Z. 2016. The formulations of site-scale processes affect landscape-scale forest change predictions: a comparison between LANDIS PRO and LANDIS-II forest landscape models. Landsc. Ecol. Springer Netherlands. doi:10.1007/s10980-016-0442-2.

Yang, J., He, H.S., Sturtevant, B.R., Miranda, B.R., and Gustafson, E.J. 2008. Comparing effects of fire modeling methods on simulated fire patterns and succession: A case study in the Missouri Ozarks. Can. J. For. Res. 38(6): 1290-1302. Available from http://www.scopus.com/inward/record.url?eid=2-s2.046749155162\&partnerID=40\&md5=d89f72c9584beba730b2c5df3c5bc928. 
Table 1. Mean stem densities in trees per acre unit by diameter class from FIA plots $(n=2039)$ in ecological section $223 A$ where fire occurred in the previous five years (Burned) or where there is no record of fire on the plot

(Unburned). The Wilcox rank-sum test was used to calculate $p$ values.

\begin{tabular}{cccc}
\hline $\begin{array}{c}\text { Diameter } \\
(\mathbf{c m})\end{array}$ & Burned & Unburned & p value \\
\hline$<=5$ & 106.0 & 186.0 & 0.0010 \\
$5-10$ & 117.0 & 152.7 & 0.0145 \\
$10-15$ & 48.2 & 63.1 & 0.5490 \\
$15-20$ & 33.5 & 35.3 & 0.8560 \\
$20-25$ & 25.1 & 25.0 & 0.7090 \\
$25-30$ & 19.1 & 17.2 & 0.1850 \\
$30-35$ & 11.6 & 10.9 & 0.8020 \\
$>35$ & 21.0 & 16.1 & 0.1350 \\
\hline
\end{tabular}

Table 2. Mean stem densities in trees per acre unit by diameter class from FIA plots $(n=4867)$ in ecological section $232 B$ where fire occurred in the previous five years (Burned) or where there is no record of fire on the plot (Unburned). The Wilcox rank-sum test was used to calculate p values.

\begin{tabular}{cccr}
\hline $\begin{array}{c}\text { Diameter } \\
(\mathbf{c m})\end{array}$ & Burn & Unburn & p value \\
\hline$<=5$ & 164.8 & 289.0 & $<0.0001$ \\
$5-10$ & 149.7 & 243.1 & $<0.0001$ \\
$10-15$ & 61.9 & 96.8 & $<0.0001$ \\
$15-20$ & 47.5 & 48.9 & 0.0844 \\
$20-25$ & 31.6 & 26.9 & 0.2225 \\
$25-30$ & 18.1 & 14.6 & 0.0135 \\
$30-35$ & 10.5 & 8.3 & 0.0030 \\
$>35$ & 14.6 & 11.8 & $<0.0001$ \\
\hline
\end{tabular}


Table 3. Mean stem densities in trees per acre unit by diameter class from 100 replications of simulating a landscape composed of randomly selected FIA plots from the ecological section 223A in LANDIS PRO. Fire mortality was estimated using a diameter based probability function (Burned) and an age-cohort based function (Cohort burned). The Tukey Honest Significant Difference test was used to test pairwise differences in the mean stem density for each diameter category across the three factor levels. Letters next to mean values indicate significant differences at a p 0.05. level.

\begin{tabular}{|c|c|c|c|c|c|c|}
\hline Diameter (cm) & Burned & & Cohort burned & & Unburned & \\
\hline$<=5$ & 133.4 & $\mathrm{a}$ & 14.6 & $\mathrm{~b}$ & 184.9 & $\mathrm{c}$ \\
\hline $5-10$ & 152.9 & $\mathrm{a}$ & 21.2 & $\mathrm{~b}$ & 164.3 & $\mathrm{a}$ \\
\hline $10-15$ & 64.5 & $\mathrm{a}$ & 13.2 & b & 63.5 & $\mathrm{a}$ \\
\hline $15-20$ & 38.2 & $\mathrm{a}$ & 5.7 & $\mathrm{~b}$ & 38.4 & $\mathrm{a}$ \\
\hline $20-25$ & 24.5 & $\mathrm{a}$ & 3.9 & b & 24.1 & $\mathrm{a}$ \\
\hline $25-30$ & 13.8 & $\mathrm{a}$ & 2.8 & $\mathrm{~b}$ & 14.3 & $\mathrm{a}$ \\
\hline $30-35$ & 10.0 & $\mathrm{a}$ & 5.3 & b & 10.0 & $\mathrm{a}$ \\
\hline$>35$ & 14.4 & $\mathrm{a}$ & 10.0 & $\mathrm{~b}$ & 14.5 & $\mathrm{a}$ \\
\hline
\end{tabular}

Table 4. Mean stem densities in trees per acre unit by diameter class from 100 replications of simulating a landscape composed of randomly selected FIA plots from the ecological section 232B in LANDIS PRO. Fire mortality was estimated using a diameter based probability function (Burned) and an age-cohort based function (Cohort burned). The Tukey Honest Significant Difference test was used to test pairwise differences in the mean stem density for each diameter category across the three factor levels. Letters next to mean values indicate significant differences at a p 0.05 . level.

\begin{tabular}{|c|c|c|c|c|c|c|}
\hline Diameter (cm) & Burned & & Cohort burned & & Unburned & \\
\hline$<=5$ & 188.7 & $\mathrm{a}$ & 35.0 & $\mathrm{~b}$ & 355.6 & $\mathrm{c}$ \\
\hline $5-10$ & 117.5 & $\mathrm{a}$ & 110.2 & $\mathrm{~b}$ & 235.9 & $\mathrm{c}$ \\
\hline $10-15$ & 97.2 & $\mathrm{a}$ & 46.0 & $\mathrm{~b}$ & 105.3 & $\mathrm{c}$ \\
\hline $15-20$ & 54.8 & $\mathrm{a}$ & 23.5 & $\mathrm{~b}$ & 58.2 & $\mathrm{c}$ \\
\hline $20-25$ & 23.8 & $\mathrm{a}$ & 12.0 & $\mathrm{~b}$ & 24.4 & $\mathrm{a}$ \\
\hline $25-30$ & 5.9 & & 5.6 & & 5.8 & \\
\hline $30-35$ & 8.3 & & 8.2 & & 8.2 & \\
\hline$>35$ & 9.1 & & 8.9 & & 9.0 & \\
\hline
\end{tabular}


Table 5. Mean number of pixels with presence of each diameter class on landscape containing plots from ecological section 223A and simulated using a diameter based probability function (Probability mortality) and an age-cohort based function (Cohort mortality) in LANDIS PRO. Welch's t-test was used to calculate p values.

\begin{tabular}{crrr}
\hline $\begin{array}{c}\text { Diameter } \\
(\mathbf{c m})\end{array}$ & $\begin{array}{r}\text { Cohort } \\
\text { mortality }\end{array}$ & $\begin{array}{r}\text { Probability } \\
\text { mortality }\end{array}$ & p value \\
\hline$<=5$ & 626 & 664 & 0.0096 \\
$5-10$ & 662 & 704 & 0.0001 \\
$10-15$ & 799 & 837 & 0.0004 \\
$15-20$ & 816 & 857 & $<0.0001$ \\
$20-25$ & 764 & 809 & $<0.0001$ \\
$25-30$ & 714 & 753 & $<0.0001$ \\
$30-35$ & 620 & 641 & 0.0447 \\
$>35$ & 690 & 700 & 0.1234 \\
\hline
\end{tabular}

Table 6. Mean number of pixels with presence of each diameter class on landscape containing plots from ecological section 232B and simulated using a diameter based probability function (Probability mortality) and an age-cohort based function (Cohort mortality) in LANDIS PRO. Welch's t-test was used to calculate p values.

\begin{tabular}{crrr}
\hline $\begin{array}{c}\text { Diameter } \\
(\mathbf{c m})\end{array}$ & $\begin{array}{r}\text { Cohort } \\
\text { mortality }\end{array}$ & $\begin{array}{r}\text { Probability } \\
\text { mortality }\end{array}$ & p value \\
\hline$<=5$ & 764 & 900 & $<0.0001$ \\
$5-10$ & 637 & 639 & 0.3401 \\
$10-15$ & 769 & 802 & $<0.0001$ \\
$15-20$ & 771 & 833 & $<0.0001$ \\
$20-25$ & 681 & 751 & $<0.0001$ \\
$25-30$ & 382 & 387 & 0.0304 \\
$30-35$ & 490 & 494 & 0.0747 \\
$>35$ & 487 & 488 & 0.8142 \\
\hline
\end{tabular}




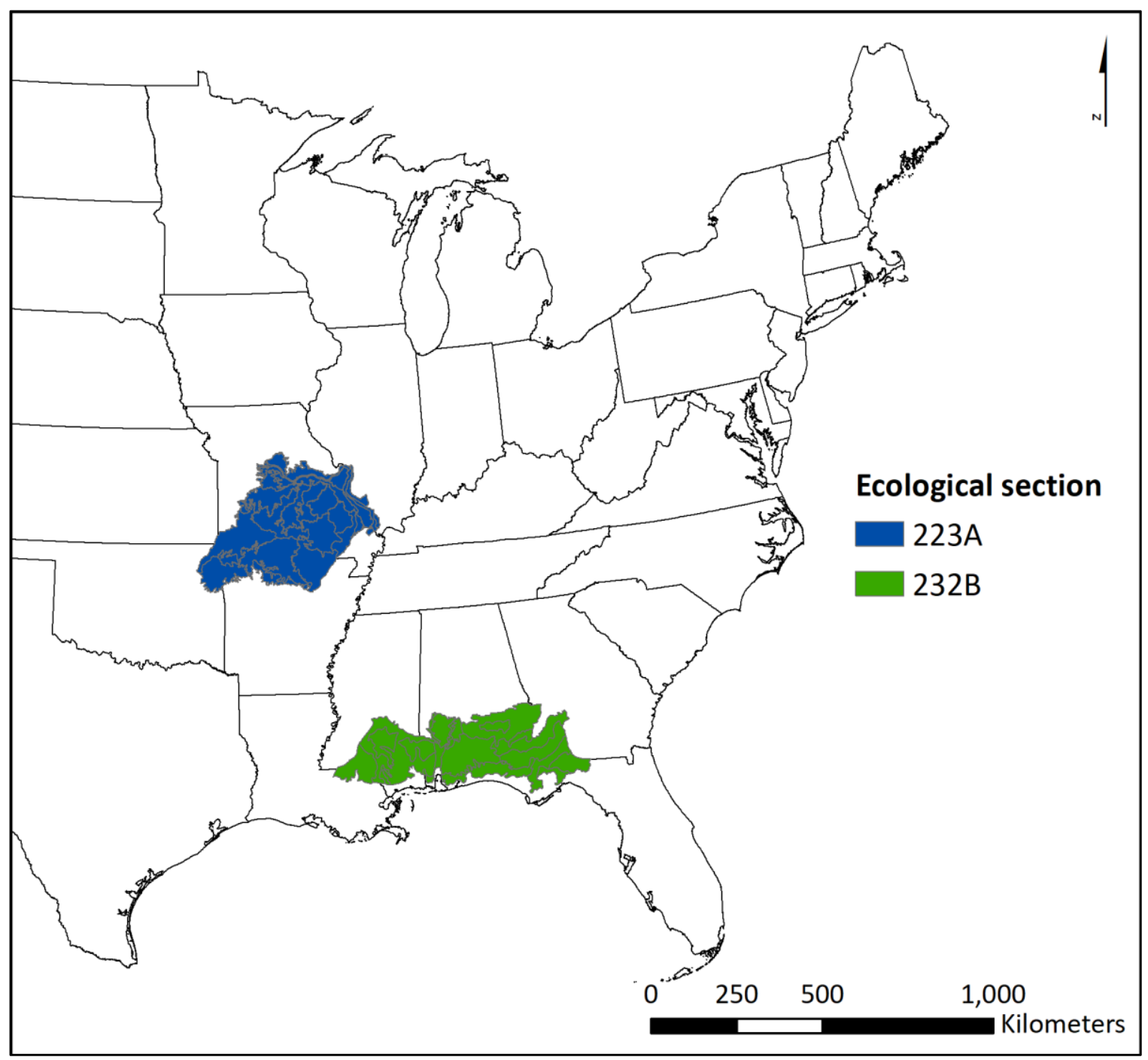

Figure 1. Two ecological sections containing forest inventory plots used for analysis. 


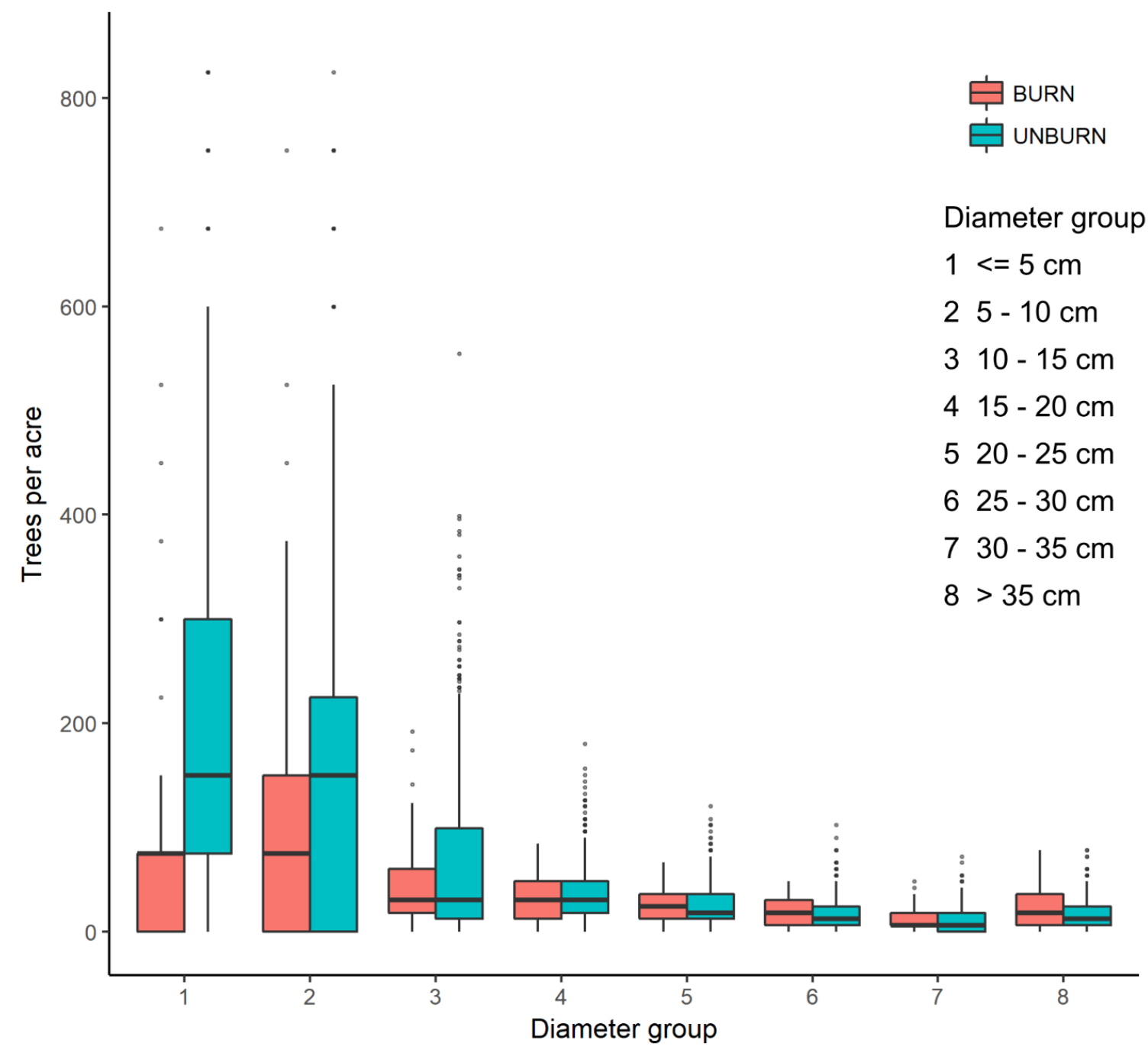

Figure 2. Boxplot showing distributions of stem densities within eight diameter groups on Forest Inventory and Analysis plots located within ecological section 223A. Plots that experienced fire within the previous five years (BURN, $n=67)$ are shown in red and plots with no fire recorded (UNBURN, $n=1972)$ are shown in blue. 


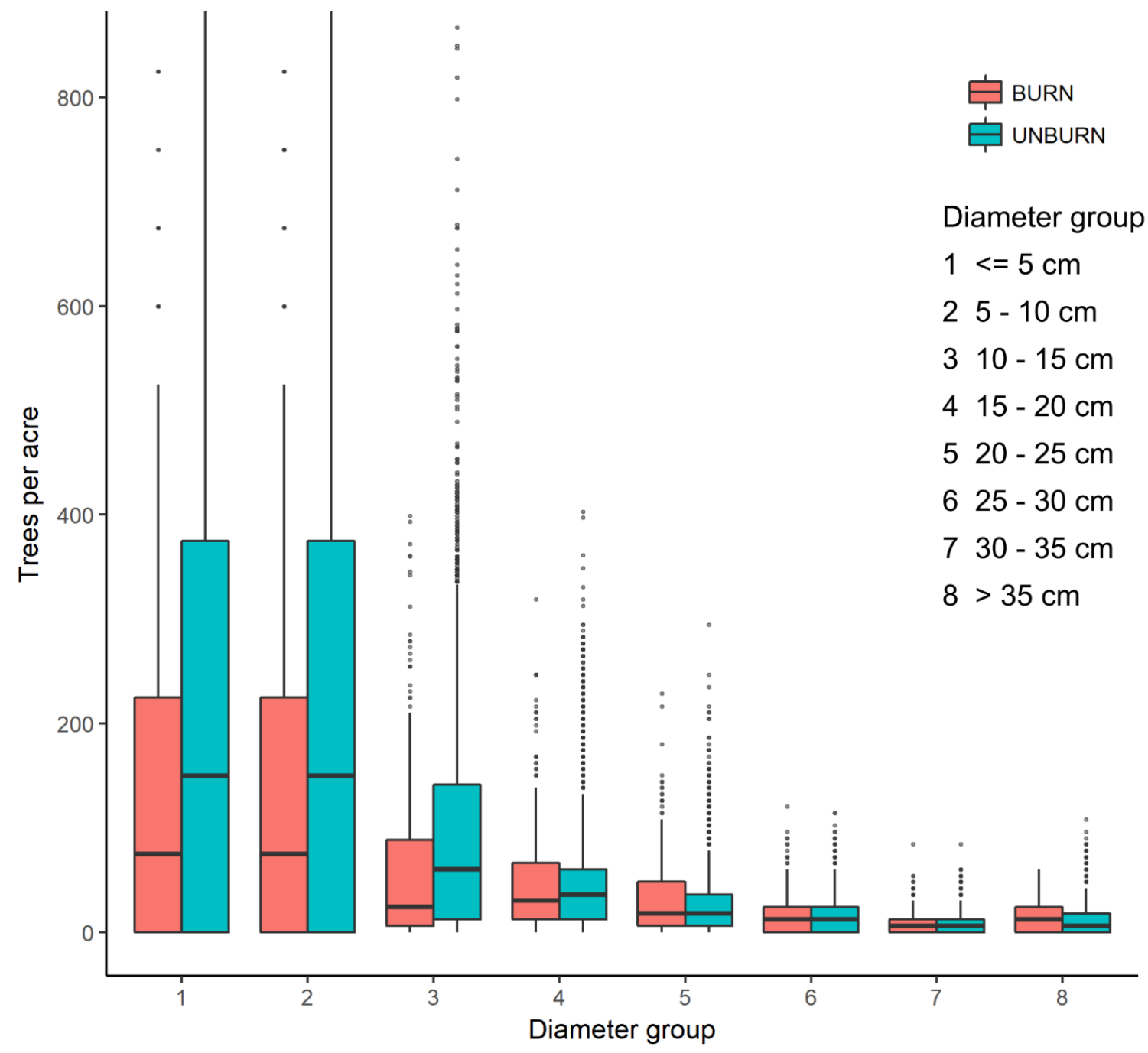

Figure 3. Boxplot showing distributions of stem densities within eight diameter groups on Forest Inventory and Analysis plots located within ecological section 232B. Plots that experienced fire within the previous five years (BURN, $n=423)$ are shown in red and plots with no fire recorded (UNBURN, $n=4444)$ are shown in blue. 


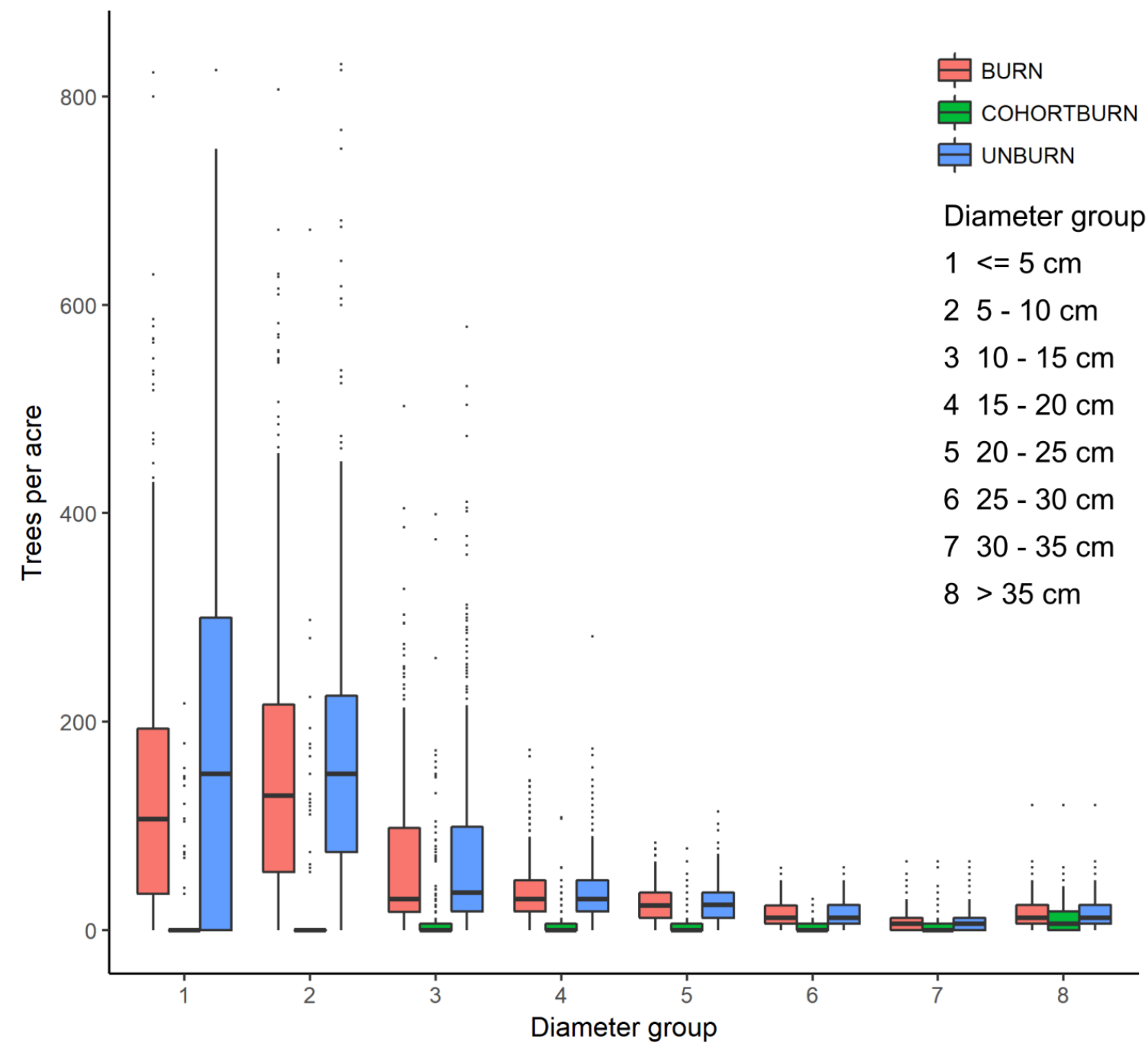

Figure 4. Boxplot showing distributions of stem densities within eight diameter groups on simulated landscapes randomly populated with plots from within ecological section 223A. Data from pixels that had fire effects simulated using the new diameter-based probability method (BURN) are shown in red. Data from pixels that had fire effects simulated using the previous age cohort-based method (COHORTBURN) are shown in green. Data from pixels with no fire simulated (UNBURN) are shown in blue. 


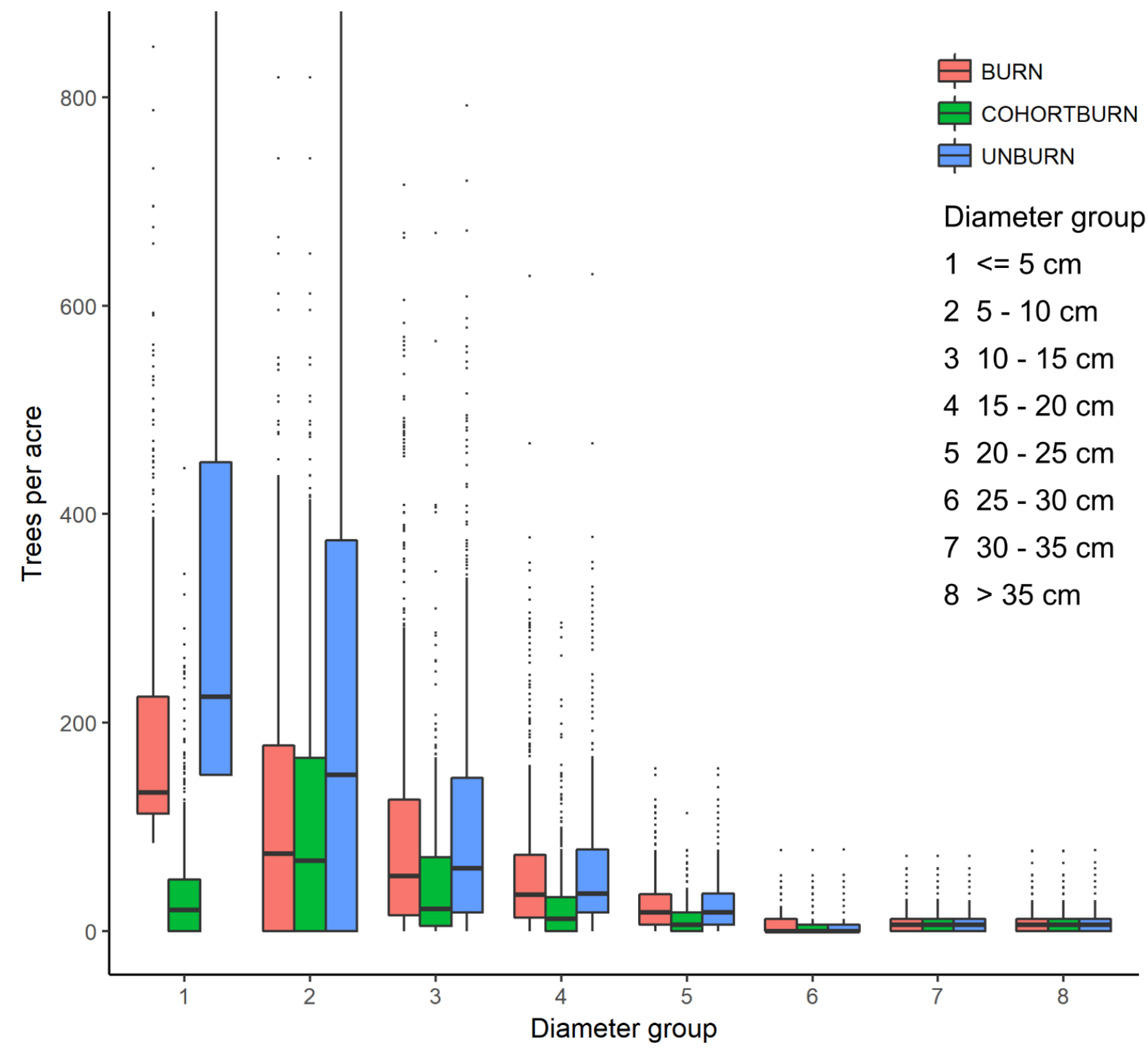

Figure 5. Boxplot showing distributions of stem densities within eight diameter groups on simulated landscapes randomly populated with plots from within ecological section 232B. Data from pixels that had fire effects simulated using the new diameter-based probability method (BURN) are shown in red. Data from pixels that had fire effects simulated using the previous age cohort-based method (COHORTBURN) are shown in green. Data from pixels with no fire simulated (UNBURN) are shown in blue. 


\section{CHAPTER 4}

\section{USING A FOREST LANDSCAPE MODEL TO SIMULATE CLIMATE CHANGE ADAPTATION STRATEGIES IN CENTRAL HARDWOOD AND SOUTHERN PINE FORESTS}

\section{INTRODUCTION}

Climate adaptation is increasingly becoming a major factor in forest management planning. A major shift in temperature and precipitation patterns could alter the suitable habitat for tree species which may lead to a drastic departure from historical conditions. In some cases, novel climate conditions may make managing to maintain current conditions or restoration to a reference condition impossible (Ravenscroft et al. 2010; Duveneck and Scheller 2016). The productivity and structure of forests could be altered by shifts in species composition (Morin et al. 2018), changes in disturbance patterns (Buma and Wessman 2011; Brown and Johnstone 2012; Serra-Diaz et al. 2015; Liang et al. 2017), or overall reduction in available resources (Breshears et al. 2005; Allen et al. 2010; Clark et al. 2016). These effects are likely to be concentrated near the edges of historical species ranges or in transitions between forest ecosystem types (Loehle 2000).

Projections of tree species ranges under climate change using niche-based approaches are in general agreement that the climatic envelopes for many species in the eastern United States will shift to the north (Schwartz et al. 2006; Mckenney et al. 2007; Iverson et al. 2008b). Although habitat for many species is projected to change under future climates the persistence of already established individuals is likely to create a lag in the effects on forests (Wang et al. 2016). As the southern boundaries of species shift northward at 
varying rates this will likely create novel interspecies interactions which could be a driver of changes in productivity or disturbance. Projections from a forest landscape model showed that disturbance can interact with forest stand processes and climate to accelerate changes in forest composition (Wang et al. 2015). Other studies have shown that incorporating individual species biological traits, such as dispersal capacity, can be an important factor in modeling climate-caused species distribution shifts (Wang et al. 2018).

The interacting dynamics that will shape forests of the future create uncertainty for managers seeking to promote healthy, resilient forests and maintain ecosystem services. Resistance based strategies generally focus on shielding vulnerable species or communities from the direct effects of climate change through management that focuses on the health of existing individuals in an attempt to maintain current conditions (Millar et al. 2007; D'Amato et al. 2011; Nagel et al. 2017). Strategies suggested to create a resistant forest community include thinning to increase productivity and health of mature individuals, decreasing disturbance, and removing exotic or invasive species (Galatowitsch et al. 2009; Nagel et al. 2017). Forest adaptation management is generally focused on proactive, rather than reactive management, in order to maintain levels of ecosystem services and to mitigate the possible negative effects of slow adaptation responses from forests. Resistance strategies, therefore, are usually recommended as short-term solutions (Millar et al. 2007; Ogden and Innes 2007; Aitken et al. 2008; Steenberg et al. 2011). Resilience adaptation strategies create forest stands more capable of responding to change through management to promote diverse species and age compositions (Ravenscroft et al. 2010; Buma and Wessman 2013; Hof et al. 2017). 
Managing for resilience is often more intensive than resistance strategies and focus on enhancing the natural adaptive capacity of a forest by creating more opportunities for existing climate-adapted species to regenerate, either through natural or artificial means (Millar et al. 2007; Ogden and Innes 2007; Duveneck and Scheller 2016; Nagel et al. 2017). A third adaptation strategy uses management with the intent to actively facilitate change to species composition or forest stand structure to a more adaptive state (Millar et al. 2007; Nagel et al. 2017). This can include the planting of future climate adapted species outside of their native ranges or drastically altering the disturbance regime and structural composition of a forest to promote a shift to new functional states (Stein et al. 2013; Duveneck and Scheller 2015).

Forest adaptation planning involves both spatial and temporal components that can provide feedback to one another and inform future decisions. Likewise, forest ecosystems respond to management, disturbance, and climate as a function of both individual species and their assemblages across the landscape. Models can be used to estimate the effects of management tactics and provide information to forest planners and policy makers..

Forest landscape models are well-suited to simulate forest management scenarios using spatially explicit landscape-level processes that interact with site-level forest stand dynamics. This allows researchers to test the possible effects of novel climatic conditions or management actions on forested landscapes over large spatial scales. Ravenscroft et al. (2010) found that a forest restoration scenario was projected to have limited success as a resistance strategy. Steenberg et al. (2011) used the LANDIS-II model to simulate the effectiveness of seven climate adaptation scenarios at preserving species of concern and maintaining old-growth reserves while still providing timber harvest services. Duveneck 
and Scheller (2015) used LANDIS-II to examine the response of forested landscapes in Minnesota and Michigan to species transition planting and increased harvest rates and found that this adaptation strategy may lead to an increase in aboveground biomass and annual net primary production.

Our objectives were to examine the interaction of climate change and forest adaptation management over 100 years in the Gulf Coastal Plains and Ozark Highlands region of the United States. Specifically, we addressed the following questions. (1) How will the importance value of tree species across the region respond to five forest adaptation scenarios under three climate scenarios? (2) How will changes to forest management under each adaptation scenario effect the overall structure of forests in the region? (3) How will the spatial distribution of five ecologically and economically important tree species in the region change under each adaptation scenario?

\section{METHODS}

\section{Study overview}

We simulated the interaction between climate change and forest management in the Gulf Coastal Plains and Ozark Highlands region in order to examine the effects of forest adaptation management options (Figure 1). Forest harvest practices and fire frequency intervals were altered to create five forest adaptation scenarios. We considered three climate scenarios: a baseline scenario based on the observed climate in the region from the time period of 1980 - 2009, a multimodel ensemble of four CMIP5 Global Climate Models (GCMs) under the Representative Concentration Pathway (RCP) 4.5 scenario 
(Figure 2), and a multimodel ensemble of four CMIP5 Global Climate Models (GCMs) under the Representative Concentration Pathway (RCP) 8.5 scenario (Figure 3).

\section{Model parameterization}

We used a linked-model approach to estimate the response of species to climate and adaptation scenarios (He et al. 1999b; Wang et al. 2015). In order to estimate the effects of abiotic factors on tree species we used a biophysical process forest model, LINKAGES 3.0 (Dijak et al. 2017). Forest stand dynamics as well as water and nutrient cycling on a forest plot were simulated using LINKAGES at a daily time-step. LINKAGES 3.0 requires parameter inputs for individual tree species attributes, soil properties, and daily climate. Species attributes include drought tolerance, shade tolerance, frost tolerance, nitrogen tolerance, growing season requirements, maximum longevity, vegetative reproduction probability, leaf litter type, crown area parameters, and seeding. We estimated species parameters from previous studies as well as literature review (Pastor and Post 1988; Burns and Honkala 1990; Wullschleger et al. 2003).

We selected soils for use in LINKAGES 3.0 by intersecting the gridded soil component map from the Natural Resources Conservation Service soil survey (SSURGO) (Staff) with an ecological subsection map and then identifying the 10 dominant soils for each of the 108 ecological subsections from which resulted in 958 soils for the study area since some smaller subsections did not contain 10 soils in total. Parameters for each layer in the selected soils were calculated from the SSURGO database.

Daily climate input data for temperature, precipitation, and wind speed for the current climate scenario $(1980-2009)$ was obtained in the form of $1 / 16^{\text {th }}$ degree gridded 
meteorological datasets (Livneh et al. 2013). LINKAGES also requires daily net solar radiation which was obtained from Daymet (Thornton et al. 2017) for the current climate scenario. For future climate scenarios we chose four GCMs under two RCP scenarios that were downscaled to $1 / 16^{\text {th }}$ degree resolution (Reclamation 2013). These downscaled GCMs contained daily values for temperature and precipitation, while wind speed and solar radiation were extracted from the non-downscaled GCM data. We chose a single point within each ecological subsection to be representative for the climate by selecting a pixel that contained the median precipitation for the time period of 1980-2009.

Precipitation was chosen due to higher variability within subsections along spatial and elevation gradients compared to temperature temperature. For consistency, these same points were used to extract climate data from the GCM model projections as well.

We used LINKAGES 3.0 to grow each of the 29 study area species from bare-ground for 30 years with no interspecies competition with 30 replicates. This was repeated for each climate scenario with the GCM scenarios broken into three time periods; 2010 - 2039, $2040-2069$, and $2070-2099$ to represent early-, mid-, and late- century responses. We used the maximum biomass from the first 30 years of growth from the LINKAGES simulations to calculate the species establishment probability (SEP) following a linked model approach (He et al. 1999b; Wang et al. 2013, 2016). In addition, we simulated plots with all species present for 200 years and 30 replicates to estimate the maximum biomass that each soil could sustain under each climate scenario. In these scenarios the 30 years of climate data specified above was recycled over the 200 years in the simulation. We averaged SEPs and maximum biomass across species, landtype, and timeperiod from the four GCMs under each RCP scenario to create an ensemble climate 
change scenario for each RCP scenario. We calculated SEPs using the methods outlined in He et al. (1999) for each species under each of the nine climate models. Due to the difficulty of averaging daily climate measurements we instead averaged the SEPs from each of the four climate models under the RCP 4.5 and RCP 8.5 scenarios to create ensemble estimates. SEP value for each decade in the $21^{\text {st }}$ century were created by interpolating between the four time periods simulated in LINKAGES.

LANDIS PRO is a grid-cell based spatially explicit forest landscape model that can simulate large landscapes over long temporal scales at a user-specified spatial resolution. By tracking stem density within age classes for individual species within each cell the model can simulate the processes of demography, stand dynamics, and disturbance. LANDIS PRO requires input parameters detailing species attributes, landtype attributes, forest composition, and disturbance patterns.

Biological attributes for the 29 species were collected from previous studies and literature (Burns and Honkala 1990; Wang et al. 2015, 2016). The landtype map was created by aggregating the gridded SSURGO component map from 10 meters to 270 meters and intersecting the result with an ecological subsection layer. Individual landtype attributes such as species establishment probability and available growing space over time were created using the process described above. Initial forest composition was estimated using the software Landscape Builder (Dijak 2013). Using Forest Inventory and Analysis (FIA) (Woodall et al. 2010) data the Landscape Builder program assigns individual plot inventory information by stratifying the landscape using the landtypes derived from the landtype map and forest type which was estimated from 2011 National Land Cover Database (Homer et al. 2012). These two layers were intersected with FIA plot locations 
to create unique combinations of landtype and forest type which was then randomly populated with attributes of species composition, density, and sizes from the database. Validation and calibration of the initial landscape and species parameters was performed using the methods outlined in Wang et al. (2014).

Disturbance rates for harvest and fire on the landscape were estimated from the LANDFIRE (2014) vegetation disturbance database. Using the 10 most recent years of data from LANDFIRE the disturbance events classified as mechanical harvest, wildfire, or prescribed fire were identified. These events were then processed using the Region Group function in the Spatial Analyst extension of ESRI ArcMap (ESRI 2015) to group disturbance events by type, intensity and year. The harvest events were summarized by ecological section to estimate mean harvest size and mean proportion of the section harvested per decade (Fraser et al. 2013). Fire events were summarized by ecological section to estimate mean fire size and mean number of ignitions per decade.

\section{Adaptation treatments}

We developed five climate adaptation scenarios to simulate within LANDIS PRO focused on resistance, resilience, or transition strategies. The adaptation scenarios altered a combination of rotation cutting lengths, silvicultural treatment type, fire frequency, or planting strategies. The no action scenario represented a baseline condition by removing harvest and fire from the landscape. By removing external sources of disturbance, mortality and establishment were controlled solely by succession dynamics within the model and the persistence of the initial trees populating the landscape was extended. The resistance scenario was designed to be a resistance strategy by extending current harvest rotations by 20 years to slightly decrease disturbance on the landscape. The resilience 
scenario was designed as a resilience strategy to promote species turnover on the landscape through shortening rotations by 20 years in order to create a diverse age class structure and allow the most adapted species to regenerate. The transition scenario was designed to promote community transition by altering the harvest and fire regimes across the landscape to create a wider range of variability in age and size structure. This scenario focused on thinning stands to a lower stocking level and increasing the frequency of lowintensity fires. In some areas where the overall productivity of forests was projected to decline, this management may promote a conversion of ecosystem type from a closedcanopy forest to a more open woodland or savanna with species composition shifting towards fire-tolerant oaks and pines. The assisted migration scenario was designed to minimize the loss of southern pine species and some oaks on the landscape by actively preparing sites and planting these species outside of their native range in addition to average harvest conditions. The species chosen for this adaptation were longleaf pine, loblolly pine, slash pine, and post oak. We selected sites for management where these species SEPs increased under climate change and that were outside of their native range. An area of approximately $4000 \mathrm{HA} / y e a r$ per species was regenerated by a clearcut or shelterwood application and planting.

\section{Experimental design}

The five adaptation scenarios were simulated in LANDIS PRO at a 270 meter resolution under each of the three climate scenarios with a 10 year time-step. Simulations were run for 100 years in order to investigate what steady-state conditions were in each of the climate and management scenarios. Disturbance under each of the five scenarios remained constant over the 100 year simulation period. 


\section{Data analysis}

We summarized the basal area and density for each species by five ecologically similar regions to assess the effects of each adaptation treatment over the landscape (Figure 4). Since management rotation periods ranged from 60 - >100 years we looked at results from the model after 300 years of simulation to examine the short- and long-term effects of each adaptation scenario. The summary of basal area and density were done for each model time-step to create continuous trajectories for each species. The importance value (IV) for each species was calculated at year 0 and at year 100 under each combination of adaptation and climate scenarios. IV is calculated using the following equation and ranges from 0 to 2 .

Equation 2

$$
I V_{i}=\left(\frac{N T_{i}}{N T_{\text {Total }}}\right)+\left(\frac{B A_{i}}{B A_{\text {Total }}}\right)
$$

Where: $I V_{i}=$ Importance value for species $i, N T_{i}=$ Number of trees of species $i, N T_{\text {Total }}=$ Total number of trees for all species, $B A_{i}=$ Basal area of species $i, B A_{\text {Total }}=$ Total basal area of all species.

We calculated the shifts in geographic centers of each species under each adaptation scenario after 100 and 300 years using the Directional Distribution tool in ESRI ArcMap (ESRI 2015). The directional distribution tool calculates the mean geographic center of a set of points which are weighted by a value, in this case we used importance value of each species, and then calculates an ellipse that covers one standard-deviation of points from the center. This allows us to identify changes in trends of dispersion for each species when compared to the geographic center at year 0 . 


\section{RESULTS}

We reported summaries from one replication of each combination of adaptation scenario and climate since variation is low among multiple replicates. Analysis of species importance value and mean center of distribution supported the theory that adaptation scenarios with higher disturbance rates, such as the transition scenario, had greater levels of change in species composition and geographic distribution. The no action and resistance scenarios which had no or lower levels of disturbance had the lowest change in species composition and geographic distribution. In general, the more ubiquitous species were more resistant to shifts in geographical distribution, while more geographically concentrated species exhibited higher levels of change under climate and adaptation scenarios.

\section{Regional Results}

\section{West Gulf Coastal Plain}

Total basal area for the region at the end of 100 years of simulation was highest under the transition scenario and closely followed by the no action scenario, while the lowest basal area was under the resilience scenario. Each of the climate scenarios caused a decrease in total basal area under all management plans, with the RCP 8.5 scenario experiencing the greatest decline from current climate amounts (Figure 5). The no action and transition scenarios under RCP 8.5 both had a difference of greater than $50 \mathrm{ft} 2 /$ acre from the current climate at the end of 100 years, while the resilience scenario had the lowest amount of decline at $35 \mathrm{ft} 2 /$ acre. 
Loblolly pine was the most dominant tree in the region, with a present day importance value (IV) of 0.6 , and this level remained relatively unchanged under the no action, resistance, resilience, and assisted migration scenarios for all climate scenarios (Table 2). The transition scenario increased the IV to slightly greater than 1.0 under all climate scenarios. Sweetgum in the most dominant hardwood species, with a starting IV of 0.195. In most scenarios it increased in IV with the largest increase occurring under the resilience strategy using current climate. Shortleaf pine increased its IV only under the transition scenario, while decreasing slightly under all other scenarios. Post oak experienced small increases in IV under all combinations while winged elm decreased slightly under all combinations. Red maple increased under all combinations, the largest being a four-times increase under scenario $3 \mathrm{RCP} 8.5$. Water oak benefitted under the no action scenario in all climates but decreased in every other combination. White oak increased under all scenarios except no action. Slash pine increased its IV under no action using climates RCP 4.5 and 8.5 while decreasing under all other combinations. Longleaf pine was minimally present in the region at year 0 and had little change under all scenarios except assisted migration where its IV increased five times.

\section{East Gulf Coastal Plain}

Total basal area for the region at the end of 100 years of simulation was highest under the transition scenario and closely followed by no action, while the lowest basal area was under the resilience scenario (Figure 6). Each of the climate scenarios caused a decrease in total basal area under all management plans, with the RCP 8.5 scenario experiencing the greatest decline from current climate amounts (Table 3). The no action and transition scenarios under RCP 8.5 both had a difference of greater than $30 \mathrm{ft} 2 /$ acre from the current 
climate at the end of 100 years, while the resilience scenario had the lowest amount of decline at $20 \mathrm{ft} 2 /$ acre.

Loblolly pine was the most dominant species in the region with a present day IV of 0.46 (Table 3). The only combination where the IV declined for loblolly pine was under the no action scenario using climate RCP 8.5. Under all other combinations the IV for loblolly pine increased, with the highest being the transition scenario, RCP 4.5 where the IV almost doubled to 0.94 . Sweetgum was the most dominant hardwood species in the region with a present-day IV of 0.233 . Sweetgum increased slightly in IV under all climate scenarios in all adaptation scenarios except the transition scenario where sweetgum's IV declined to nearly half of its starting value after 100 years of simulation. Water oak is the third most dominant species in the region and declined in IV under all climates in all scenarios except the no action scenario where the IV of water oak increased with the highest occurring in climate RCP 8.5. Red maple increased in IV under all scenarios and climates with the largest increases occurring in the resilience scenario. White oak increased in IV under all scenarios and climates with the largest increase occurring in the transition scenario under the current climate. Slash pine increased across the region under the no action scenario and nearly doubled in IV under the assisted migration scenario using the RCP 8.5 climate. Longleaf pine's IV increased under all scenarios except using current climate in the resistance and resilience scenarios. The greatest increase in IV for longleaf pine occurred under the assisted migration scenario using the RCP 8.5 climate. Shortleaf pine started with an IV of 0.028 and increased under nearly all scenarios except all climates in the no action scenario and the RCP 8.5 climate in the resistance and assisted migration scenarios. Post oak increased 
under all combinations and doubled in IV under the transition scenario using current climate.

\section{Interior Highlands}

Total basal area for the Interior Highlands followed similar trajectories under all management scenarios, with the no action scenario reaching a slightly higher maximum (Figure 7). Both future climate scenarios reduced the maximum basal area to similar levels across all adaptation scenarios.

White oak was the most dominant species in the region with a present-day IV of 0.277 (Table 4). The IV of white oak increased under all combinations, with the highest being 0.551 under scenario $4 \mathrm{RCP} 4.5$. Across all adaptation scenarios the IV of white oak for future climate scenarios was higher than under current climate. Post oak was also a dominant species with a present-day IV of 0.235 and also increased in IV under all scenario combinations. Likewise, black oak increased in IV under all scenario combinations with the highest being scenario $1 \mathrm{RCP} 8.5$. Other oaks modeled in the region had little change in IV under adaptation or climate scenario. Shortleaf pine had small declines in IV under all adaptation scenarios except scenario 4 which had small increases. Mockernut hickory had small increases or decreases in IV across scenarios while winged elm and blackgum declined. Red maple increased its IV across all combinations and generally responded best under higher disturbance rates. Loblolly pine had a small present-day IV in the region, 0.001, which declined slightly under adaptation scenarios 1, 2, and 3. Scenario 4 increased its IV slightly, with the highest increase occurring under RCP 8.5. Scenario 5, which focused on planting loblolly in this region outside of its native range produced a large increase in IV. 


\section{Mississippi Alluvial Valley}

Total basal area in the Mississippi Alluvial Valley was highest under no action and lowest under resilience (Figure 8). The RCP 8.5 climate scenario caused the largest decline in maximum basal area under no action and the lowest under resilience.

The region was dominated by bottomland species such as sugarberry, bald cypress, green ash, and sweetgum at present (Table 5). Sugarberry had a present-day IV of 0.223 which increased under all combinations. The largest increase for sugarberry occurred under resistance and under each adaptation scenario using the RCP 8.5 climate had the highest IV for the species. Sweetgum followed a similar pattern, although it did not benefit as much under the future climate scenarios. Bald cypress had a present-day IV of 0.176 which declined by half or more under all scenario combinations. Green ash increased in IV under the resistance, resilience, and assisted migration scenarios and declined under the no action and transition scenarios. Loblolly pine increased in IV under all scenario combinations, with the highest occurring under the transition scenario. White oak declined under all scenarios, while post oak had small increases in most adaptation scenarios and doubled in IV under the transition scenario. Shortleaf pine, longleaf pine, and slash pine all had minimal changes in IV except for the assisted migration scenario where planting increased the IV of longleaf and slash pine in the region.

\section{Gulf Coast}

The Gulf Coast region was the only region where total basal area increased under the future climate scenarios (Figure 9). Each adaptation scenario had the highest basal area under the RCP 4.5 climate and the lowest under the current climate. No action had the 
highest overall basal areas, followed by transition, resistance, and assisted migration, and then resilience with the lowest. This region was also the only region where the basal area after 100 years was lower than the present-day basal area for the region under any of the adaptation scenarios.

Red maple was the most dominant species in the region with a present-day IV of 0.273 (Table 6). It increased in IV under all scenarios and benefitted most from higher rates of disturbance such as in the resilience scenario. Red maple also had higher IVs under future climate scenarios with RCP 8.5 producing the highest values across all adaptation scenarios. Swamp tupelo declined by approximately half under all adaptation scenarios except the transition scenario where it declined to a quarter of its present-day IV. Slash pine increased under all scenarios, with the highest increase occurring under no action. Bald cypress, green ash, and water tupelo all declined in IV under all combinations. Loblolly pine and longleaf pine both increased under all adaptation scenarios, especially transition which caused loblolly to overtake slash pine as the most dominant pine in the region. White oak and shortleaf pine both responded well with increasing IVs under the resistance, resilience, transition, and assisted migration scenarios.

\section{Species Landscape Response}

Across the region, the weighted center of white oak remained relatively stable compared to its present-day distribution (Figure 10). The no action scenario under future climate scenarios caused the southern edge of the mean distribution to shift northward, while the transition scenario caused the southern edge to expand south under all climate scenarios. In general, each of the future climate scenarios had a smaller mean distribution than the current climate for white oak. 
The mean distribution area for shortleaf pine increased the most under the resilience scenario using the current climate, while the transition scenario had the highest expansion under RCP 8.5. The no action scenario had little effect on the mean distribution of shortleaf pine under any climate scenario (Figure 11).

Loblolly pine remained stable in its mean distribution after 100 years under all adaptation scenarios and climates (Figure 12). Longleaf pine experienced a decrease in the area of its mean distribution under the no action, resistance, resilience, and transition scenarios, with the greatest decline occurring under transition (Figure 13). Assisted migration, which had targeted site preparation and planting in areas where longleaf was projected to have favorable conditions, expanded the mean distribution to the northwest. The RCP 8.5 and RCP 4.5 climate scenario mean distributions for longleaf pine were either the same as under current climate or larger.

Slash pine remained stable under no action, while resistance, resilience, and transition expanded the mean distribution slightly, while assisted migration nearly doubled the area of the mean distribution (Figure 14). Climate had little effect on the mean distribution under any adaptation scenario.

\section{DISCUSSION}

When developing management and adaptation strategies for the future, forest managers and policy makers must take many different aspects of forest ecosystem services into account. Timber harvest is a major component of the economy in much of the study area as well as the main driver of forest disturbance (Wear and Greis 2002). While none of the adaptation scenarios here specifically use forest economics as a component, they do use 
some common mechanisms in forest planning such as rotation length, species selection, and harvest type. In conventional timber harvest planning, economics normally plays a major role in rotation length and the adjustment of those rotations in these management strategies may be unrealistic in that context. However, working only within the framework of past practices and economic constraints limits the number of tools available to managers for operating within potentially novel conditions.

The no action scenario was designed to be the control by removing direct management intervention from the landscape and allowing the forests to react to climate only through succession and stand dynamics (Nagel et al. 2017). Under no action the importance values for all species had the lowest amount of change at the end of the century when compared against present-day values, although there was greater amounts of change under the two future climate scenarios. In addition, the mean center of the distribution for most species under the no action scenario closely approximated that of present-day. This illustrates the concept that disturbance plays a key role in the rate of response of species to climate change (Wang et al. 2016) and that the vulnerability of a species to climate change is most often expressed during establishment (Millar et al. 2007). Given the minimal level of disturbance on the landscape and relatively young age of the forest at the beginning of simulation, few species experienced large changes in importance value under this scenario. Some of the focal species had a greater increase in IV under the future climates for this adaptation scenario. Longleaf pine, post oak, slash pine and white oak all had a higher average IV under RCP 4.5 and RCP 8.5 when compared to current climate after 100 years of simulation. While shortleaf pine declined on average under all climate scenarios, it declined the least under RCP 8.5. As expected, basal area over the 
region was highest under the no action scenario, and after 100 years the landscape had the least diverse age structure, with most trees belonging to the 90 years or greater category (Figure 15).

The resistance scenario was a resistance strategy that increased harvest rotations by 20 years to decrease disturbance over the landscape and adjusted harvest practices to favor the regeneration of existing species. The mean range of change in IV for this adaptation scenario was slightly higher than no action. This adaptation strategy was effective at maintaining or increasing IV under future climate scenarios for nearly all of the focus species. Loblolly pine, longleaf pine, post oak, and white oak all had higher IVs for one or both of the future climate scenarios when compared against the current climate. Slash pine declined under all climates but had the smallest decrease under RCP 8.5, suggesting that its decrease is due to disturbance rather than climate. Shortleaf pine decreased under both future climate scenarios on average across the landscape although its mean spatial distribution increased to the southeast which suggests the decreases occurred where it is most abundant on the landscape at present-day. This scenario maintained a landscape where the oldest age class had the highest IV and still contained a large representation of the other age classes.

The resilience scenario was designed to increase forest resilience by increasing disturbance through shorter harvest rotations. These shorter rotations provided more opportunities for the species that are most adapted to any changes in climate to regenerate over the next century. This scenario had nearly the same effect on species IVs as resistance, where shortleaf pine and slash pine declined under the future climate scenarios and loblolly pine, longleaf pine, post oak, and white oak all had higher IVs under on or 
both future climate scenarios. In each of the other scenarios the age composition at the landscape scale was dominated by the 90 year or older class, while in resilience the distribution is much more even across the age classes.

The transition scenario had the largest departure from current harvest and management practices as a strategy to promote forest transition. Forests were selectively thinned to increase resources for residual trees as well as favor species predicted to be better suited to future climates. In addition, the frequency of low-intensity fire was increased to promote fire-tolerant oak or pine regeneration. This strategy produced a higher maximum basal area across the landscape than all other adaptation scenarios except no action. About half of the IV on the landscape was composed of trees in the 90 years or greater age class while the other age classes accounted for between $7 \%$ and $17 \%$ of IV. This scenario had the greatest effect on species composition with all of the focus species except slash pine increasing in IV. Shortleaf pine increased in all regions through natural regeneration and its mean spatial distribution increased in size due to a doubling of IV in the southeast region. This is in contrast to other scenarios where the mean spatial distribution increased due to a decline in IV in the regions where shortleaf pine is traditionally dominant. Loblolly pine increased to the highest IVs under any adaptation scenario and maintained that advantage under both RCP scenarios. This increase mainly came at the expense of sweetgum and red maple which both had large increases in IV under other scenarios but decreased, as in the case of sweetgum, or, as in the case of red maple, did not increase as much under this management scenario. This transition scenario was the most aggressive, and perhaps most unrealistic, at the landscape scale, but serves to highlight that targeted high-intensity management has the potential to maintain a 
vigorous dominant canopy class while at the same time promoting the regeneration of a more climate and disturbance tolerant understory.

The assisted migration scenario approximated current harvest and fire levels with a fixed amount of targeted facilitated migration. Sites were chosen for each species based on estimations from LINKAGES of sites outside the native range where the establishment probability increased under future climate scenarios. These sites all constituted a northern shift for the species with loblolly pine planted in northern Arkansas and southeast Missouri, while slash pine and longleaf pine were targeted north of their current ranges in Louisiana, Mississippi, and Alabama. This strategy increased the IV of loblolly pine slightly over the no action, resistance, and resilience scenarios but not to the levels seen under the transition scenario. Loblolly pine did increase in IV in the Interior Highlands region where facilitated migration was targeted, but after analysis of stand-level results, this increase likely came at the expense of shortleaf pine. Longleaf pine benefitted most under this scenario, more than doubling its IV under the RCP 8.5 scenario. Slash pine had a similar response, almost doubling in IV under the RCP 8.5 with smaller increases under current climate and RCP 4.5. The mean spatial distribution of longleaf and slash pine illustrate that this increase is not only occurring in the present-day range of the species but establishment and growth is successful in the targeted regions.

\section{CONCLUSION}

We examined a range of potential forest adaptation strategies to estimate what effect they would have on the distribution and importance value of species as well as the structure of forests as a whole. Some species, such as loblolly pine and white oak benefitted under all 
adaptation scenarios due to a high dominance on the landscape to start with and positive response to future climates. The transition scenario which simulated a highly managed alteration of forest structure and disturbance regimes was the only strategy that maintained shortleaf pine's importance on the landscape under future climate scenarios. Obviously, one strategy for adaptation will not work across entire landscapes for all species in reality. Managers must prioritize and adapt to accommodate many factors that are not included in this study, such as available resources and economic returns. In this study area where privately held industrial forests make up a majority of the forest area under management, these non-ecologically related factors will likely be more influential in decisions than in other systems. Future studies to examine adaptation strategies may need to incorporate an economic component in the modeling effort in order to provide more useful assessments of the efficacies of this type of management. 


\section{LITERATURE CITED}

Aitken, S.N., Yeaman, S., Holliday, J.A., Wang, T., and Curtis-McLane, S. 2008.

Adaptation, migration or extirpation: climate change outcomes for tree populations. Evol. Appl. 1(1): 95-111. doi:10.1111/j.1752-4571.2007.00013.x.

Allen, C.D., Macalady, A.K., Chenchouni, H., Bachelet, D., McDowell, N., Vennetier, M., Kitzberger, T., Rigling, A., Breshears, D.D., Hogg, E.H. (Ted), Gonzalez, P., Fensham, R., Zhang, Z., Castro, J., Demidova, N., Lim, J.-H., Allard, G., Running, S.W., Semerci, A., and Cobb, N. 2010. A global overview of drought and heatinduced tree mortality reveals emerging climate change risks for forests. For. Ecol. Manage. 259(4): 660-684. doi:10.1016/j.foreco.2009.09.001.

Breshears, D.D., Cobb, N.S., Rich, P.M., Price, K.P., Allen, C.D., Balice, R.G., Romme, W.H., Kastens, J.H., Floyd, M.L., Belnap, J., Anderson, J.J., Myers, O.B., and Meyer, C.W. 2005. Regional vegetation die-off in response to global-change-type drought. Proc. Natl. Acad. Sci. U. S. A. 102(42): 15144-8. doi:10.1073/pnas.0505734102.

Brown, C.D., and Johnstone, J.F. 2012. Once burned, twice shy: Repeat fires reduce seed availability and alter substrate constraints on Picea mariana regeneration. For. Ecol. Manage. 266: 34-41. Elsevier B.V. doi:10.1016/j.foreco.2011.11.006.

Buma, B., and Wessman, C.A. 2011. Disturbance interactions can impact resilience mechanisms of forests. Ecosphere 2(5). doi:10.1890/ES11-00038.1.

Buma, B., and Wessman, C.A. 2013. Forest resilience, climate change, and opportunities 
for adaptation: A specific case of a general problem. For. Ecol. Manage. 306: 216225. Elsevier B.V. doi:10.1016/j.foreco.2013.06.044.

Burns, R.M., and Honkala, B.H. 1990. Silvics of North America: Volume 2: Hardwoods. In Agriculture Handbook 654.

Clark, J.S., Iverson, L., Woodall, C.W., Allen, C.D., Bell, D.M., Bragg, D.C., D’Amato, A.W., Davis, F.W., Hersh, M.H., Ibanez, I., Jackson, S.T., Matthews, S., Pederson, N., Peters, M., Schwartz, M.W., Waring, K.M., and Zimmermann, N.E. 2016. The impacts of increasing drought on forest dynamics, structure, and biodiversity in the United States. Glob. Chang. Biol. 22(7): 2329-2352. doi:10.1111/gcb.13160.

D’Amato, A.W., Bradford, J.B., Fraver, S., and Palik, B.J. 2011. Forest management for mitigation and adaptation to climate change: Insights from long-term silviculture experiments. For. Ecol. Manage. 262(5): 803-816. Elsevier B.V. doi:10.1016/j.foreco.2011.05.014.

Dijak, W. 2013. Landscape Builder : Software for the creation of initial landscapes for LANDIS from FIA data. Comput. Ecol. Softw. 3(2): 17-25. doi:10.0000/issn-2220721x-compuecol-2013-v3-0003.

Dijak, W.D., Hanberry, B.B., Fraser, J.S., He, H.S., Wang, W.J., and Thompson, F.R. 2017. Revision and application of the LINKAGES model to simulate forest growth in central hardwood landscapes in response to climate change. Landsc. Ecol.: 1-20. doi:10.1007/s10980-016-0473-8.

Duveneck, M.J., and Scheller, R.M. 2015. Climate-suitable planting as a strategy for 
maintaining forest productivity and functional diversity. Ecol. Appl. 25(6): 16531668. doi:10.1890/14-0738.1.

Duveneck, M.J., and Scheller, R.M. 2016. Measuring and managing resistance and resilience under climate change in northern Great Lake forests (USA). Landsc. Ecol. 31(3): 669-686. Springer Netherlands. doi:10.1007/s10980-015-0273-6.

ESRI. 2015. ArcMap Desktop: Release 10.3.1. Environmental Systems Research Institute, Redlands, CA.

Fraser, J.S., He, H.S., Shifley, S.R., Wang, W.J., and Thompson, F.R. 2013. Simulating stand-level harvest prescriptions across landscapes: LANDIS PRO harvest module design. Can. J. For. Res. 43(10): 972-978. NRC Research Press. doi:10.1139/cjfr2013-0190.

Galatowitsch, S., Frelich, L., and Phillips-Mao, L. 2009. Regional climate change adaptation strategies for biodiversity conservation in a midcontinental region of North America. Biol. Conserv. 142(10): 2012-2022. Elsevier. doi:10.1016/J.BIOCON.2009.03.030.

He, H.S., Mladenoff, D.J., and Crow, T.R. 1999. Linking an ecosystem model and a landscape model to study forest species response to climate warming. Ecol. Modell. 114(2-3): 213-233. Available from http://www.scopus.com/inward/record.url?eid=2-s2.00032928948\&partnerID=40\&md5=f5d3ed7596ff7bfa28ead2eb492f68cc.

Hof, A.R., Dymond, C.C., and Mladenoff, D.J. 2017. Climate change mitigation through 
adaptation: the effectiveness of forest diversification by novel tree planting regimes. Ecosphere (November). doi:10.1002/ecs2.1981.

Homer, C., Fry, J., and Barnes, C.A. 2012. The National Land Cover Database. US Geol. Surv. Fact Sheet (February): 1-4. Available from http://pubs.usgs.gov/fs/2012/3020/.

Iverson, L.R., Prasad, A.M., Matthews, S.N., and Peters, M. 2008. Estimating potential habitat for 134 eastern US tree species under six climate scenarios. For. Ecol. Manage. 254(3): 390-406. doi:10.1016/j.foreco.2007.07.023.

LANDFIRE. 2014. Vegetation Disturbance Layer. LANDFIRE 1.4.0, U.S. Department of the Interior, Geological Survey.

Liang, Y., Duveneck, M.J., Gustafson, E.J., Serra-Diaz, J.M., and Thompson, J.R. 2017. How disturbance, competition, and dispersal interact to prevent tree range boundaries from keeping pace with climate change. Glob. Chang. Biol. (April 2017): 335-351. doi:10.1111/gcb.13847.

Livneh, B., Rosenberg, E. a., Lin, C., Nijssen, B., Mishra, V., Andreadis, K.M., Maurer, E.P., and Lettenmaier, D.P. 2013. A long-term hydrologically based dataset of land surface fluxes and states for the conterminous United States: Update and extensions. J. Clim. 26(23): 9384-9392. doi:10.1175/JCLI-D-12-00508.1.

Loehle, C. 2000. Forest ecotone response to climate change: sensitivity to temperature response functional forms. Can. J. For. Res. 30(10): 1632-1645. doi:10.1139/x00088. 
Mckenney, D.W., Pedlar, J.H., Lawrence, K., Hutchinson, M.F., Kenney, D.W.M.C., and Campbell, K. 2007. Potential Impacts of Climate Change on the Distribution of North American Trees. BioOne 57(11): 939-948. doi:10.1641/B571106.

Millar, C.I., Stephenson, N.L., and Stephens, S.L. 2007. Climate change and forest of the future: Managing in the face of uncertanity. Ecol. Appl. 17(8): 2145-2151. doi:http://dx.doi.org/10.1890/06-1715.1.

Morin, X., Fahse, L., Jactel, H., Scherer-Lorenzen, M., García-Valdés, R., and Bugmann, H. 2018. Long-term response of forest productivity to climate change is mostly driven by change in tree species composition. Sci. Rep. 8(1): 5627. doi:10.1038/s41598-018-23763-y.

Nagel, L.M., Palik, B.J., Battaglia, M.A., D’Amato, A.W., Guldin, J.M., Swanston, C.W., Janowiak, M.K., Powers, M.P., Joyce, L.A., Millar, C.I., Peterson, D.L., Ganio, L.M., Kirschbaum, C., and Roske, M.R. 2017. Adaptive Silviculture for Climate Change: A National Experiment in Manager-Scientist Partnerships to Apply an Adaptation Framework. J. For. 115(3): 167-178. doi:10.5849/jof.16-039.

Ogden, A.E., and Innes, J. 2007. Incorporating climate change adaptation considerations into forest management planning in the boreal forest. Int. For. Rev. 9(3): 713-733. doi:10.1505/ifor.9.3.713.

Pastor, J., and Post, W. 1988. Response of northern forests to CO2-induced climate change. Nature 334: 55-58. Available from http://www.nature.com/nature/journal/v334/n6177/abs/334055a0.html [accessed 16 October 2014]. 
Ravenscroft, C., Scheller, R.M., Mladenoff, D.J., and White, M.A. 2010. Forest restoration in a mixed-ownership landscape under climate change. Ecol. Appl. 20(2): 327-346. doi:10.1890/08-1698.1.

Reclamation. 2013. Downscaled CMIP3 and CMIP5 Climate Projections: Release of Downscaled CMIP5 Climate Projections, Comparison with Preceding Information, and Summary of User Needs. U.S. Department of the Interior, Bureau of Reclamation, Technical Service Center, Denver, Colorado. Available from http://gdodcp.ucllnl.org/downscaled_cmip_projections/techmemo/downscaled_climate.pdf.

Schwartz, M.W., Iverson, L.R., Prasad, A.M., Matthews, S.N., and O’Connor, R.J. 2006. Predicting Extinction as a Result of Climate Change. Ecology 87(7): 1611-1615. Wiley-Blackwell. doi:10.1890/0012-9658(2006)87[1611:PEAARO]2.0.CO;2.

Serra-Diaz, J.M., Scheller, R.M., Syphard, A.D., and Franklin, J. 2015. Disturbance and climate microrefugia mediate tree range shifts during climate change. Landsc. Ecol. (Woodward 1987). doi:10.1007/s10980-015-0173-9.

Staff, S.S. (n.d.). Soil Survey Geographic (SSURGO) Database. Available from http://websoilsurvey.nrcs.usda.gov/ [accessed 10 January 2015].

Steenberg, J.W.N., Duinker, P.N., and Bush, P.G. 2011. Exploring adaptation to climate change in the forests of central Nova Scotia, Canada. For. Ecol. Manage. 262(12): 2316-2327. Elsevier B.V. doi:10.1016/j.foreco.2011.08.027.

Stein, B.A., Staudt, A., Cross, M.S., Dubois, N.S., Enquist, C., Griffis, R., Hansen, L.J., 
Hellmann, J.J., Lawler, J.J., Nelson, E.J., and Pairis, A. 2013. Preparing for and managing change: climate adaptation for biodiversity and ecosystems. Front. Ecol. Environ. 11(9): 502-510. Wiley-Blackwell. doi:10.1890/120277.

Thornton, P.E., Thornton, M.M., Mayer, B.W., Wei, Y., Devarakonda, R., Vose, R.S., and Cook, R.B. 2017. Daymet: Daily Surface Weather Data on a 1-km Grid for North America, Version 3. Oak Ridge, Tennessee, USA. doi:10.3334/ORNLDAAC/1328.

Wang, W.J., He, H.S., Spetich, M.A., Shifley, S.R., Thompson, F.R., Dijak, W.D., and Wang, Q. 2014. A framework for evaluating forest landscape model predictions using empirical data and knowledge. Environ. Model. Softw. 62: 230-239. doi:10.1016/j.envsoft.2014.09.003.

Wang, W.J., He, H.S., Spetich, M.A., Shifley, S.R., Thompson III, F.R., Larsen, D.R., Fraser, J.S., and Yang, J. 2013. A large-scale forest landscape model incorporating multi-scale processes and utilizing forest inventory data. Ecosphere 4(9): 1-22. doi:10.1890/ES13-00040.1.

Wang, W.J., He, H.S., Thompson, F.R., Spetich, M.A., and Fraser, J.S. 2018. Effects of species biological traits and environmental heterogeneity on simulated tree species distribution shifts under climate change. Sci. Total Environ. 634: 1214-1221. Elsevier B.V. doi:10.1016/j.scitotenv.2018.03.353.

Wang, W.J., He, H.S., Thompson III, F.R., Fraser, J.S., and Dijak, W.D. 2016. Changes in forest biomass and tree species distribution under climate change in the northeastern United States. Landsc. Ecol. Springer Netherlands. 
doi:10.1007/s10980-016-0429-z.

Wang, W.J., He, H.S., Thompson III, F.R., Fraser, J.S., Hanberry, B.B., and Dijak, W.D. 2015. The importance of succession, harvest, and climate change in determining future forest composition changes of the U.S. Central Hardwood Forests. Ecosphere 6(12): art277. doi:10.1890/ES15-00238.1.

Wear, D.N., and Greis, J.G. 2002. The southern forest resource assessment: summary report. 54.

Woodall, C., Conkling, B., Amacher, M., Coulston, J., Jovan, S., Perry, C., Schulz, B., Smith, G., and Will Wolf, S. 2010. The forest inventory and analysis database version 4.0: database description and users manual for phase 3. Newtown Square, PA. Available from http://www.treesearch.fs.fed.us/pubs/35009 [accessed 1 October 2012].

Wullschleger, S., Gunderson, C., Tharp, M.L., West, D., and Post, W.M. 2003. Simulated patterns of forest succession and productivity as a consequence of altered precipitation. In North American temperate deciduous forest responses to changing precipitation regimes. Edited by P. Hanson and S. Wullschleger. Springer, New York, New York, USA. pp. 433-446. 
Table 1. Table of the 5\% and 95\% percentiles of species establishment probabilities over the entire study area for each species modeled in LINKAGES 3.0 under three climate scenarios. Green shading indicates an increase in SEP

compared to current climate, red shading indicates a decrease in modeled SEP compared to current climate.

\begin{tabular}{|c|c|c|c|c|c|c|}
\hline \multirow[b]{2}{*}{ Species } & \multicolumn{2}{|c|}{ Current Climate } & \multicolumn{2}{|c|}{$\begin{array}{l}\text { Ensemble } \quad \text { RCP } \\
4.5\end{array}$} & \multicolumn{2}{|c|}{$\begin{array}{l}\text { Ensemble } \\
8.5\end{array}$} \\
\hline & $5 \%$ & $95 \%$ & $5 \%$ & $95 \%$ & $5 \%$ & $95 \%$ \\
\hline American elm & 0.221 & 0.553 & 0.201 & 0.517 & 0.113 & 0.483 \\
\hline bald cypress & 0.023 & 0.042 & 0.038 & 0.042 & 0.037 & 0.042 \\
\hline black cherry & 0.272 & 0.654 & 0.251 & 0.604 & 0.229 & 0.559 \\
\hline black oak & 0.433 & 0.647 & 0.028 & 0.626 & 0.000 & 0.597 \\
\hline blackgum & 0.154 & 0.582 & 0.140 & 0.542 & 0.120 & 0.504 \\
\hline cherrybark oak & 0.027 & 0.042 & 0.007 & 0.042 & 0.000 & 0.042 \\
\hline green ash & 0.294 & 0.590 & 0.107 & 0.543 & 0.000 & 0.518 \\
\hline laurel oak & 0.011 & 0.042 & 0.035 & 0.042 & 0.038 & 0.042 \\
\hline loblolly pine & 0.136 & 0.548 & 0.271 & 0.507 & 0.105 & 0.488 \\
\hline longleaf pine & 0.013 & 0.043 & 0.036 & 0.043 & 0.027 & 0.043 \\
\hline mockernut hickory & 0.522 & 0.659 & 0.267 & 0.632 & 0.042 & 0.605 \\
\hline northern red oak & 0.000 & 0.600 & 0.000 & 0.581 & 0.000 & 0.509 \\
\hline overcup oak & 0.168 & 0.513 & 0.024 & 0.453 & 0.000 & 0.420 \\
\hline post oak & 0.208 & 0.453 & 0.193 & 0.427 & 0.056 & 0.405 \\
\hline red maple & 0.460 & 0.742 & 0.393 & 0.703 & 0.353 & 0.647 \\
\hline shortleaf pine & 0.249 & 0.508 & 0.000 & 0.448 & 0.000 & 0.420 \\
\hline slash pine & 0.000 & 0.046 & 0.026 & 0.046 & 0.035 & 0.046 \\
\hline southern red oak & 0.402 & 0.595 & 0.179 & 0.579 & 0.000 & 0.567 \\
\hline sugar maple & 0.000 & 0.627 & 0.000 & 0.149 & 0.000 & 0.000 \\
\hline sugarberry & 0.197 & 0.561 & 0.209 & 0.535 & 0.178 & 0.521 \\
\hline swamp tupelo & 0.000 & 0.041 & 0.000 & 0.039 & 0.000 & 0.035 \\
\hline sweetgum & 0.188 & 0.699 & 0.173 & 0.638 & 0.074 & 0.589 \\
\hline water oak & 0.035 & 0.043 & 0.038 & 0.042 & 0.009 & 0.042 \\
\hline water tupelo & 0.025 & 0.042 & 0.007 & 0.041 & 0.000 & 0.041 \\
\hline white ash & 0.504 & 0.660 & 0.177 & 0.614 & 0.023 & 0.579 \\
\hline white oak & 0.443 & 0.600 & 0.000 & 0.583 & 0.000 & 0.562 \\
\hline willow oak & 0.037 & 0.043 & 0.008 & 0.042 & 0.000 & 0.042 \\
\hline winged elm & 0.332 & 0.598 & 0.299 & 0.578 & 0.096 & 0.553 \\
\hline yellow-poplar & 0.406 & 0.777 & 0.254 & 0.701 & 0.079 & 0.630 \\
\hline
\end{tabular}


Table 2. Selected species importance values under each adaptation and climate scenario in the West Gulf Coastal Plain region at year 100. Green shading represents an increase in IV over time, red shading represents a decrease in IV over time, orange shading is the lowest IV for the species across all scenarios, blue shading is the highest IV across all scenarios.

\begin{tabular}{|c|c|c|c|c|c|c|c|c|c|c|c|c|c|c|c|c|}
\hline & & \multicolumn{2}{|c|}{ No action } & \multicolumn{4}{|c|}{ Resistance } & \multicolumn{2}{|c|}{ Resilience } & \multicolumn{4}{|c|}{ Transition } & \multicolumn{3}{|c|}{ Assisted migration } \\
\hline & & Current & RCP 4.5 & RCP 8.5 & Current & RCP 4.5 & RCP 8.5 & Current & RCP 4.5 & RCP 8.5 & Current & RCP 4.5 & RCP 8.5 & Current & RCP 4.5 & RCP 8.5 \\
\hline loblolly pine & 0.604 & 0.644 & 0.626 & 0.604 & 0.627 & 0.634 & 0.613 & 0.607 & 0.615 & 0.594 & 1.031 & 1.023 & 1.002 & 0.636 & 0.642 & 0.619 \\
\hline sweetgum & 0.195 & 0.210 & 0.199 & 0.187 & 0.288 & 0.270 & 0.266 & 0.289 & 0.273 & 0.269 & 0.113 & 0.113 & 0.114 & 0.281 & 0.262 & 0.257 \\
\hline shortleaf pine & 0.132 & 0.111 & 0.114 & 0.112 & 0.121 & 0.107 & 0.096 & 0.127 & 0.108 & 0.098 & 0.154 & 0.143 & 0.135 & 0.119 & 0.103 & 0.092 \\
\hline post oak & 0.107 & 0.145 & 0.151 & 0.152 & 0.151 & 0.158 & 0.160 & 0.150 & 0.157 & 0.159 & 0.154 & 0.161 & 0.164 & 0.153 & 0.160 & 0.162 \\
\hline winged elm & 0.077 & 0.031 & 0.030 & 0.026 & 0.039 & 0.037 & 0.037 & 0.040 & 0.039 & 0.038 & 0.016 & 0.017 & 0.015 & 0.038 & 0.036 & 0.036 \\
\hline red maple & 0.064 & 0.131 & 0.147 & 0.171 & 0.166 & 0.171 & 0.196 & 0.200 & 0.200 & 0.225 & 0.088 & 0.095 & 0.110 & 0.177 & 0.179 & 0.203 \\
\hline water oak & 0.062 & 0.089 & 0.098 & 0.117 & 0.045 & 0.051 & 0.059 & 0.041 & 0.048 & 0.056 & 0.034 & 0.039 & 0.045 & 0.043 & 0.049 & 0.056 \\
\hline white oak & 0.062 & 0.060 & 0.059 & 0.052 & 0.097 & 0.093 & 0.078 & 0.098 & 0.094 & 0.081 & 0.105 & 0.097 & 0.083 & 0.092 & 0.088 & 0.075 \\
\hline slash pine & 0.023 & 0.020 & 0.026 & 0.030 & 0.011 & 0.014 & 0.016 & 0.010 & 0.012 & 0.014 & 0.011 & 0.013 & 0.015 & 0.016 & 0.020 & 0.022 \\
\hline longleaf pine & 0.004 & 0.004 & 0.004 & 0.004 & 0.002 & 0.002 & 0.003 & 0.002 & 0.002 & 0.002 & 0.004 & 0.005 & 0.005 & 0.018 & 0.021 & 0.024 \\
\hline
\end{tabular}


Table 3. Selected species importance values under each adaptation and climate scenario in the East Gulf Coastal Plain region at year 100. Green shading represents an increase in $I V$ over time, red shading represents a decrease in IV over time, orange shading is the lowest IV for the species across all scenarios, blue shading is the highest IV across all scenarios.

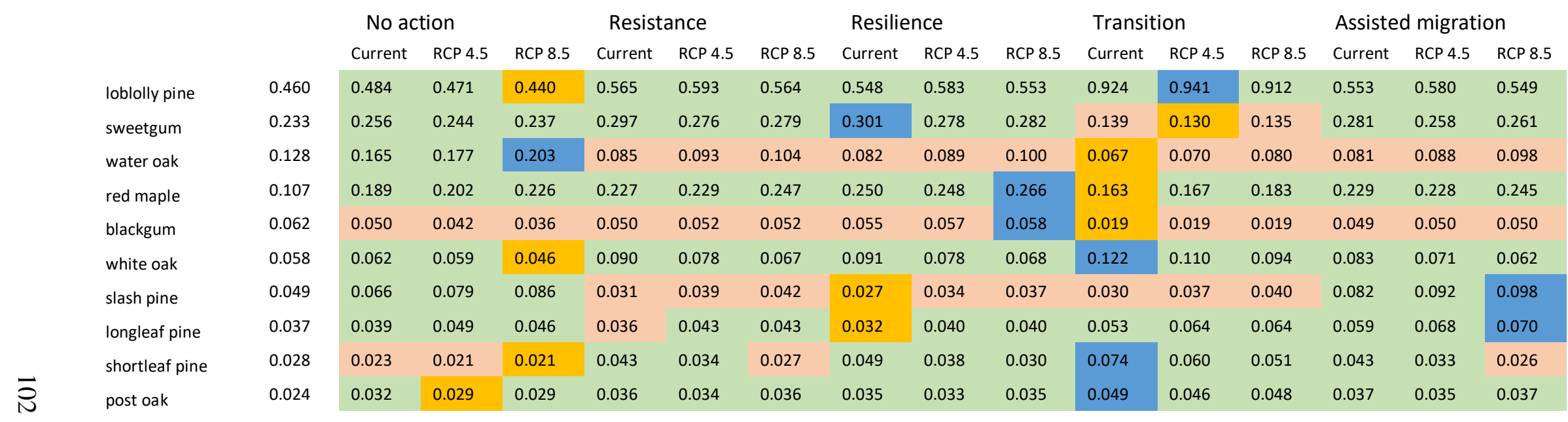


Table 4. Selected species importance values under each adaptation and climate scenario in the Interior Highlands region at year 100. Green shading represents an increase in IV over time, red shading represents a decrease in IV over time, orange shading is the lowest IV for the species across all scenarios, blue shading is the highest IV across all scenarios.

\begin{tabular}{|c|c|c|c|c|c|c|c|c|c|c|c|c|c|c|c|c|}
\hline & & \multicolumn{2}{|c|}{ No action } & \multicolumn{4}{|c|}{ Resistance } & \multicolumn{2}{|c|}{ Resilience } & \multicolumn{4}{|c|}{ Transition } & \multicolumn{3}{|c|}{ Assisted migration } \\
\hline & & Current & RCP 4.5 & RCP 8.5 & Current & RCP 4.5 & RCP 8.5 & Current & RCP 4.5 & RCP 8.5 & Current & RCP 4.5 & RCP 8.5 & Current & RCP 4.5 & RCP 8.5 \\
\hline white oak & 0.277 & 0.314 & 0.439 & 0.545 & 0.454 & 0.523 & 0.473 & 0.459 & 0.523 & 0.474 & 0.453 & 0.551 & 0.496 & 0.433 & 0.495 & 0.447 \\
\hline post oak & 0.235 & 0.274 & 0.250 & 0.285 & 0.311 & 0.294 & 0.295 & 0.313 & 0.295 & 0.296 & 0.343 & 0.315 & 0.316 & 0.299 & 0.281 & 0.281 \\
\hline black oak & 0.212 & 0.381 & 0.432 & 0.472 & 0.299 & 0.361 & 0.389 & 0.300 & 0.361 & 0.388 & 0.276 & 0.325 & 0.351 & 0.291 & 0.348 & 0.374 \\
\hline shortleaf pine & 0.103 & 0.081 & 0.073 & 0.092 & 0.102 & 0.092 & 0.094 & 0.102 & 0.092 & 0.094 & 0.134 & 0.118 & 0.122 & 0.097 & 0.088 & 0.089 \\
\hline mockernut hickory & 0.065 & 0.059 & 0.060 & 0.062 & 0.065 & 0.064 & 0.066 & 0.066 & 0.064 & 0.066 & 0.066 & 0.064 & 0.066 & 0.062 & 0.061 & 0.062 \\
\hline northern red oak & 0.059 & 0.070 & 0.069 & 0.048 & 0.054 & 0.058 & 0.060 & 0.054 & 0.058 & 0.059 & 0.054 & 0.056 & 0.058 & 0.052 & 0.055 & 0.057 \\
\hline winged elm & 0.054 & 0.014 & 0.014 & 0.020 & 0.015 & 0.014 & 0.013 & 0.016 & 0.014 & 0.014 & 0.011 & 0.011 & 0.011 & 0.015 & 0.013 & 0.013 \\
\hline blackgum & 0.050 & 0.025 & 0.027 & 0.054 & 0.025 & 0.025 & 0.026 & 0.026 & 0.026 & 0.026 & 0.017 & 0.021 & 0.021 & 0.024 & 0.024 & 0.024 \\
\hline red maple & 0.043 & 0.097 & 0.086 & 0.062 & 0.102 & 0.093 & 0.099 & 0.103 & 0.093 & 0.099 & 0.100 & 0.087 & 0.093 & 0.100 & 0.089 & 0.095 \\
\hline loblolly pine & 0.001 & 0.001 & 0.001 & 0.001 & 0.001 & 0.001 & 0.001 & 0.001 & 0.001 & 0.001 & 0.001 & 0.002 & 0.002 & 0.089 & 0.091 & 0.095 \\
\hline
\end{tabular}


Table 5. Selected species importance values under each adaptation and climate scenario in the Mississippi Alluvial Valley region at year 100. Green shading represents an increase in IV over time, red shading represents a decrease in IV over time, orange shading is the lowest IV for the species across all scenarios, blue shading is the highest IV across all scenarios.

\begin{tabular}{|c|c|c|c|c|c|c|c|c|c|c|c|c|c|c|c|c|}
\hline & & \multicolumn{2}{|c|}{ No action } & \multicolumn{4}{|c|}{ Resistance } & \multicolumn{2}{|c|}{ Resilience } & \multicolumn{4}{|c|}{ Transition } & \multicolumn{3}{|c|}{ Assisted migration } \\
\hline & & Current & RCP 4.5 & RCP 8.5 & Current & RCP 4.5 & RCP 8.5 & Current & RCP 4.5 & RCP 8.5 & Current & RCP 4.5 & RCP 8.5 & Current & RCP 4.5 & RCP 8.5 \\
\hline sugarberry & 0.223 & 0.360 & 0.389 & 0.401 & 0.414 & 0.450 & 0.462 & 0.371 & 0.394 & 0.397 & 0.399 & 0.425 & 0.438 & 0.402 & 0.432 & 0.439 \\
\hline bald cypress & 0.176 & 0.082 & 0.086 & 0.089 & 0.044 & 0.051 & 0.052 & 0.036 & 0.040 & 0.041 & 0.066 & 0.078 & 0.083 & 0.038 & 0.044 & 0.045 \\
\hline green ash & 0.162 & 0.150 & 0.136 & 0.132 & 0.222 & 0.194 & 0.174 & 0.206 & 0.194 & 0.178 & 0.148 & 0.134 & 0.123 & 0.225 & 0.199 & 0.180 \\
\hline sweetgum & 0.129 & 0.227 & 0.217 & 0.211 & 0.228 & 0.221 & 0.207 & 0.184 & 0.177 & 0.164 & 0.207 & 0.200 & 0.190 & 0.211 & 0.203 & 0.189 \\
\hline loblolly pine & 0.023 & 0.081 & 0.083 & 0.078 & 0.066 & 0.067 & 0.060 & 0.062 & 0.062 & 0.055 & 0.118 & 0.122 & 0.109 & 0.068 & 0.068 & 0.063 \\
\hline white oak & 0.022 & 0.014 & 0.016 & 0.014 & 0.017 & 0.017 & 0.015 & 0.017 & 0.017 & 0.016 & 0.020 & 0.021 & 0.018 & 0.016 & 0.016 & 0.015 \\
\hline post oak & 0.013 & 0.015 & 0.019 & 0.019 & 0.014 & 0.017 & 0.017 & 0.014 & 0.017 & 0.017 & 0.020 & 0.025 & 0.024 & 0.014 & 0.017 & 0.017 \\
\hline shortleaf pine & 0.004 & 0.003 & 0.003 & 0.003 & 0.003 & 0.003 & 0.003 & 0.003 & 0.003 & 0.002 & 0.007 & 0.006 & 0.005 & 0.003 & 0.003 & 0.002 \\
\hline longleaf pine & 0.001 & 0.001 & 0.001 & 0.002 & 0.001 & 0.001 & 0.001 & 0.001 & 0.001 & 0.001 & 0.001 & 0.002 & 0.002 & 0.002 & 0.003 & 0.003 \\
\hline slash pine & 0.001 & 0.001 & 0.002 & 0.002 & 0.000 & 0.001 & 0.001 & 0.000 & 0.000 & 0.000 & 0.001 & 0.001 & 0.001 & 0.005 & 0.005 & 0.005 \\
\hline
\end{tabular}


Table 6. Selected species importance values under each adaptation and climate scenario in the Gulf Coast region at year 100. Green shading represents an increase in IV over time, red shading represents a decrease in IV over time, orange shading is the lowest IV for the species across all scenarios, blue shading is the highest IV across all scenarios.

\begin{tabular}{|c|c|c|c|c|c|c|c|c|c|c|c|c|c|c|c|c|}
\hline & & \multicolumn{2}{|c|}{ No action } & \multicolumn{4}{|c|}{ Resistance } & \multicolumn{2}{|c|}{ Resilience } & \multicolumn{4}{|c|}{ Transition } & \multicolumn{3}{|c|}{ Assisted migration } \\
\hline & & Current & RCP 4.5 & RCP 8.5 & Current & RCP 4.5 & RCP 8.5 & Current & RCP 4.5 & RCP 8.5 & Current & RCP 4.5 & RCP 8.5 & Current & RCP 4.5 & RCP 8.5 \\
\hline red maple & 0.273 & 0.415 & 0.478 & 0.517 & 0.749 & 0.733 & 0.815 & 0.845 & 0.793 & 0.853 & 0.663 & 0.676 & 0.742 & 0.836 & 0.797 & 0.878 \\
\hline swamp tupelo & 0.255 & 0.169 & 0.152 & 0.145 & 0.119 & 0.113 & 0.108 & 0.114 & 0.117 & 0.116 & 0.067 & 0.064 & 0.062 & 0.110 & 0.108 & 0.103 \\
\hline slash pine & 0.200 & 0.320 & 0.370 & 0.379 & 0.205 & 0.229 & 0.234 & 0.208 & 0.222 & 0.229 & 0.205 & 0.227 & 0.235 & 0.201 & 0.220 & 0.225 \\
\hline bald cypress & 0.187 & 0.085 & 0.075 & 0.082 & 0.044 & 0.052 & 0.052 & 0.032 & 0.039 & 0.040 & 0.114 & 0.104 & 0.114 & 0.034 & 0.042 & 0.042 \\
\hline green ash & 0.154 & 0.095 & 0.073 & 0.063 & 0.129 & 0.126 & 0.099 & 0.135 & 0.138 & 0.120 & 0.071 & 0.071 & 0.059 & 0.127 & 0.126 & 0.102 \\
\hline water tupelo & 0.126 & 0.123 & 0.103 & 0.103 & 0.081 & 0.066 & 0.069 & 0.063 & 0.057 & 0.060 & 0.054 & 0.044 & 0.046 & 0.067 & 0.057 & 0.059 \\
\hline loblolly pine & 0.056 & 0.095 & 0.089 & 0.080 & 0.145 & 0.157 & 0.109 & 0.143 & 0.162 & 0.116 & 0.318 & 0.328 & 0.263 & 0.140 & 0.155 & 0.109 \\
\hline longleaf pine & 0.044 & 0.064 & 0.076 & 0.067 & 0.063 & 0.068 & 0.065 & 0.067 & 0.069 & 0.067 & 0.100 & 0.114 & 0.108 & 0.063 & 0.067 & 0.064 \\
\hline white oak & 0.003 & 0.003 & 0.001 & 0.001 & 0.012 & 0.009 & 0.009 & 0.015 & 0.012 & 0.011 & 0.018 & 0.014 & 0.013 & 0.013 & 0.010 & 0.010 \\
\hline shortleaf pine & 0.001 & 0.002 & 0.002 & 0.001 & 0.008 & 0.004 & 0.002 & 0.008 & 0.004 & 0.003 & 0.017 & 0.007 & 0.006 & 0.007 & 0.004 & 0.002 \\
\hline
\end{tabular}




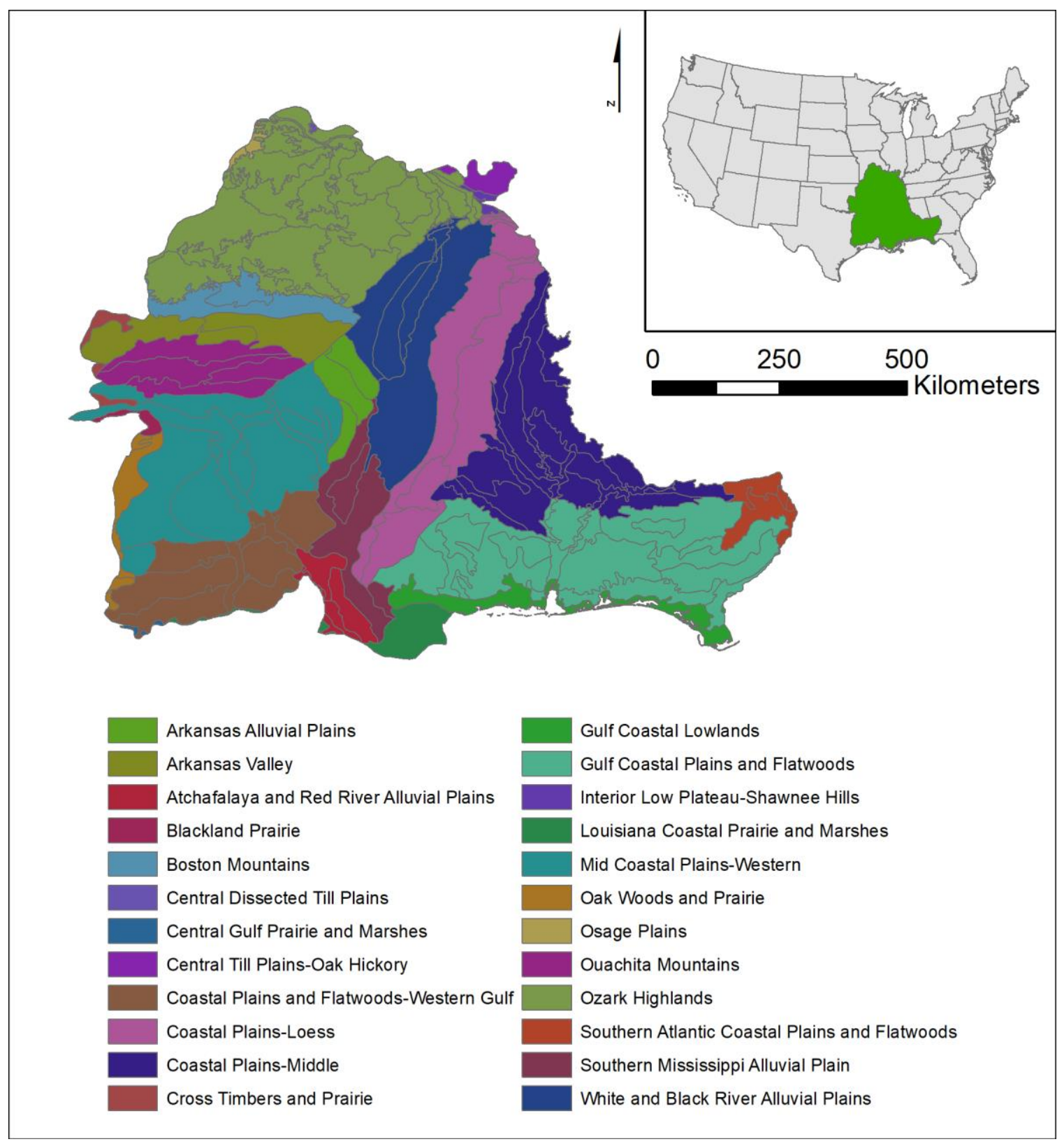

Figure 1. The ecological sections of the Gulf Coastal Plains and Ozark Highlands region. 

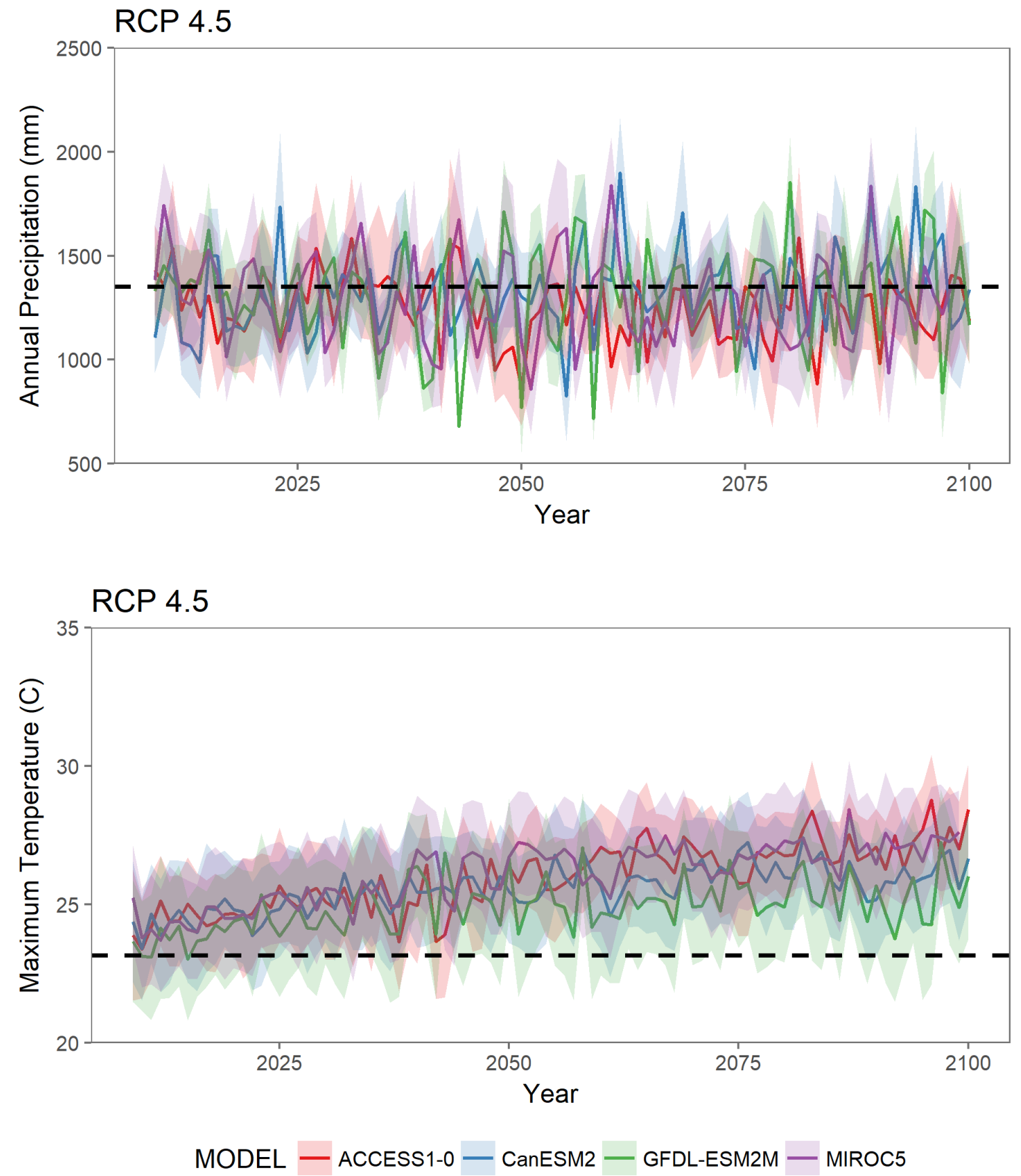

Figure 2. The total annual precipitation and mean maximum temperature for the study region from four global circulation models using the representative control pathway 4.5 scenario. Dashed black line represents the average of each variable over the years $1980-2009$. 

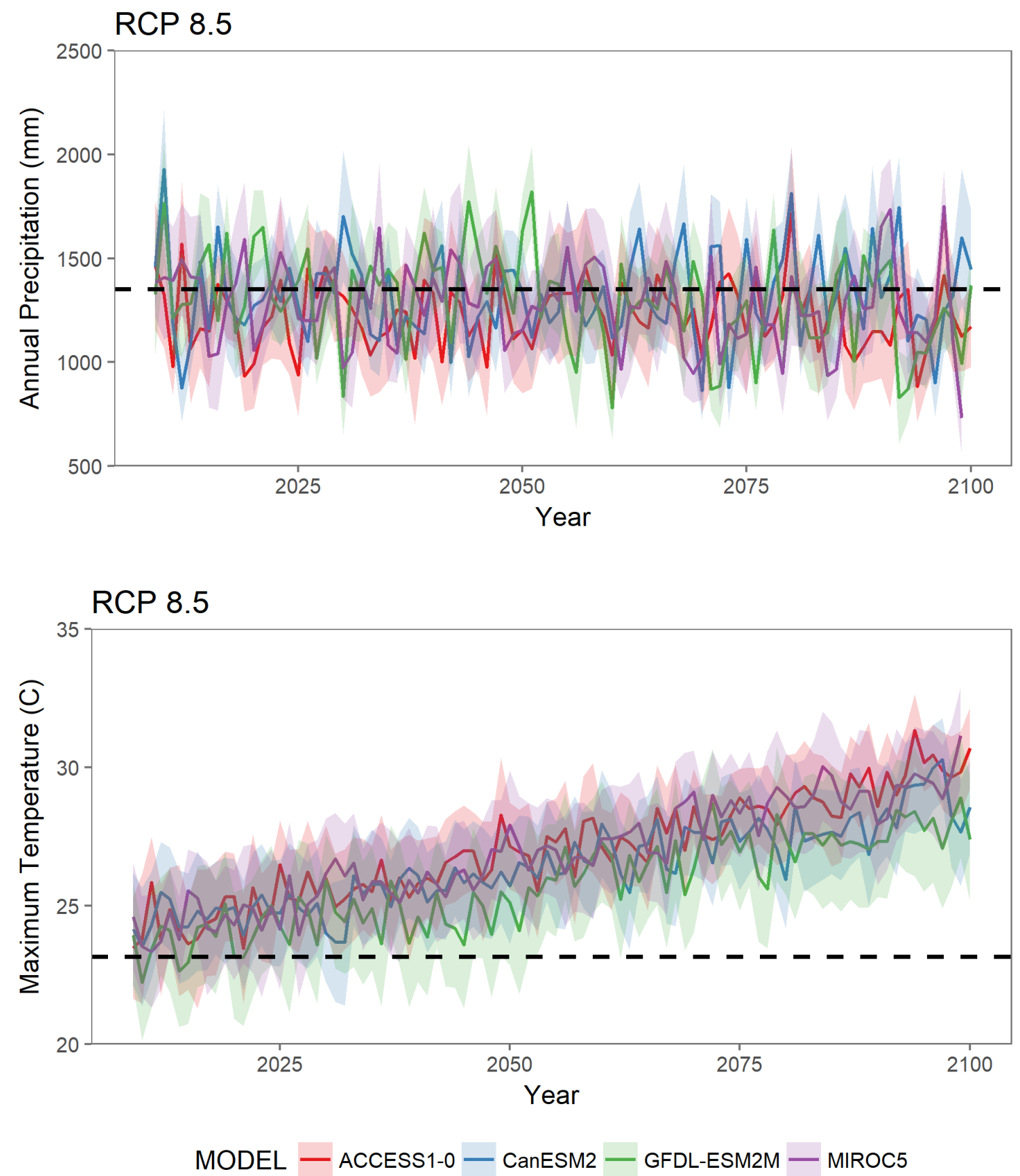

Figure 3. The total annual precipitation and mean maximum temperature for the study region from four global circulation models using the representative control pathway 8.5 scenario. Dashed black line represents the average of each variable over the years $1980-2009$. 


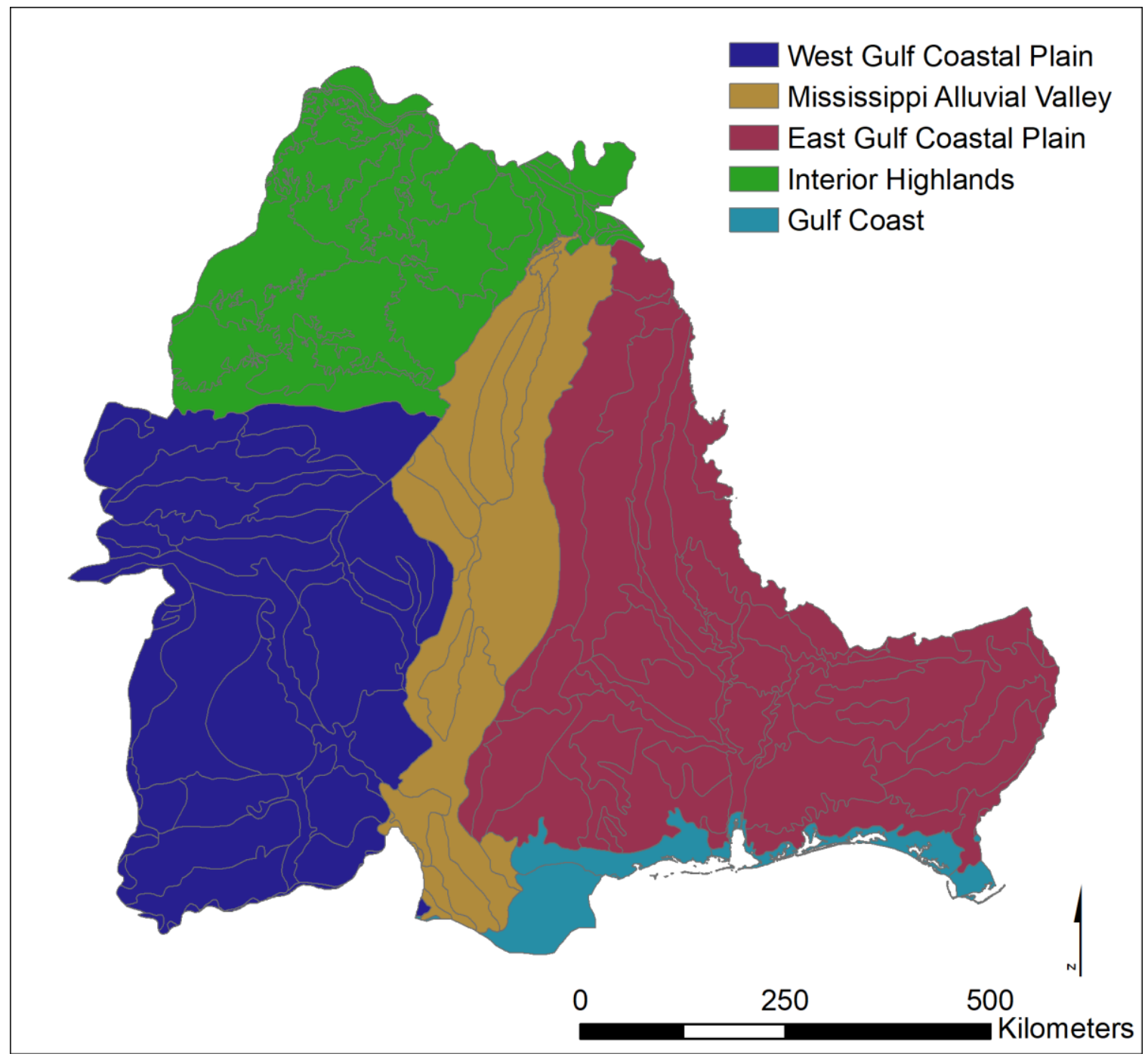

Figure 4. Regions used for summarizing results of importance value and basal area. 


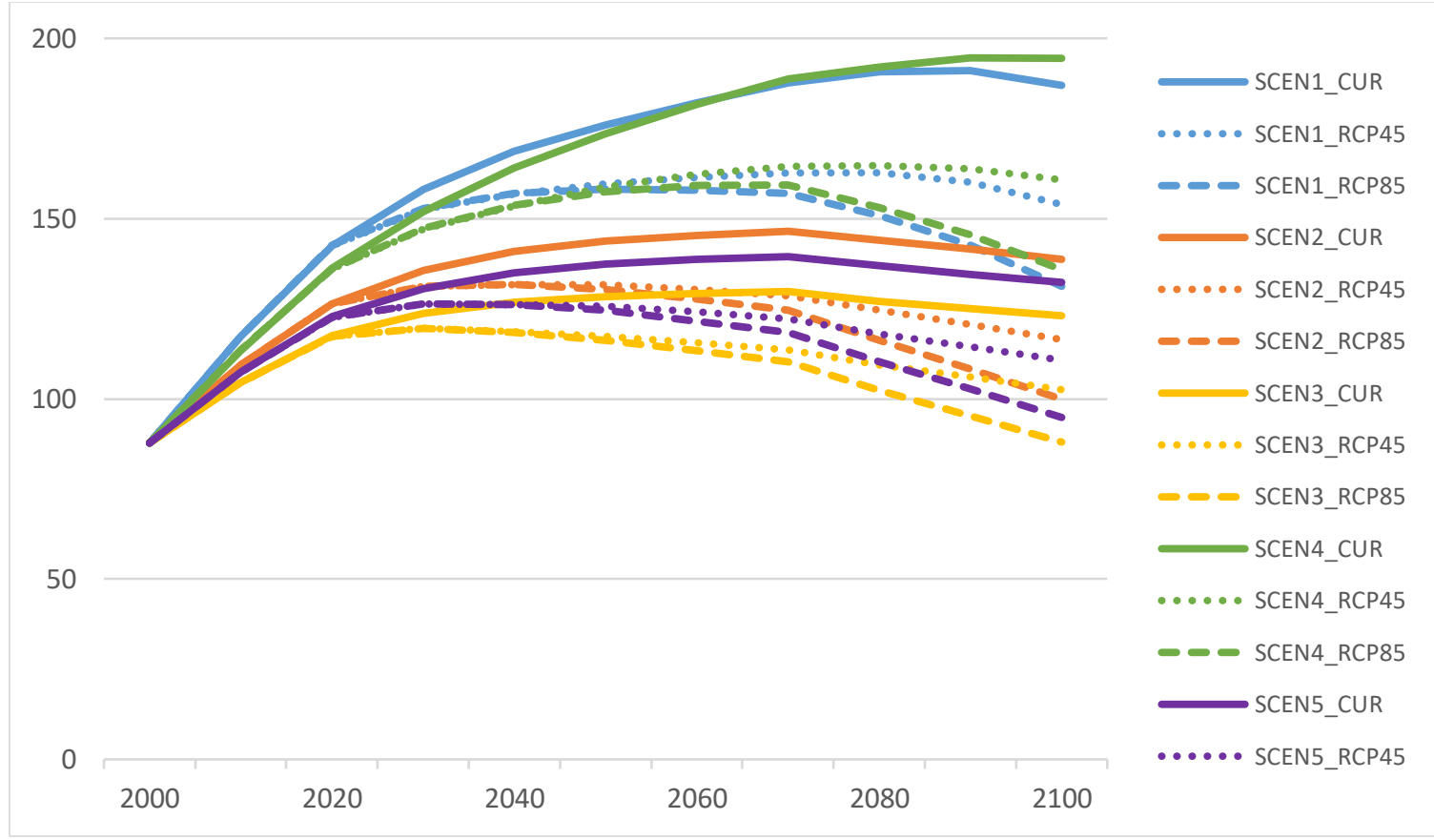

Figure 5. Total basal area (ft//acre) for the West Gulf Coastal Plain region.

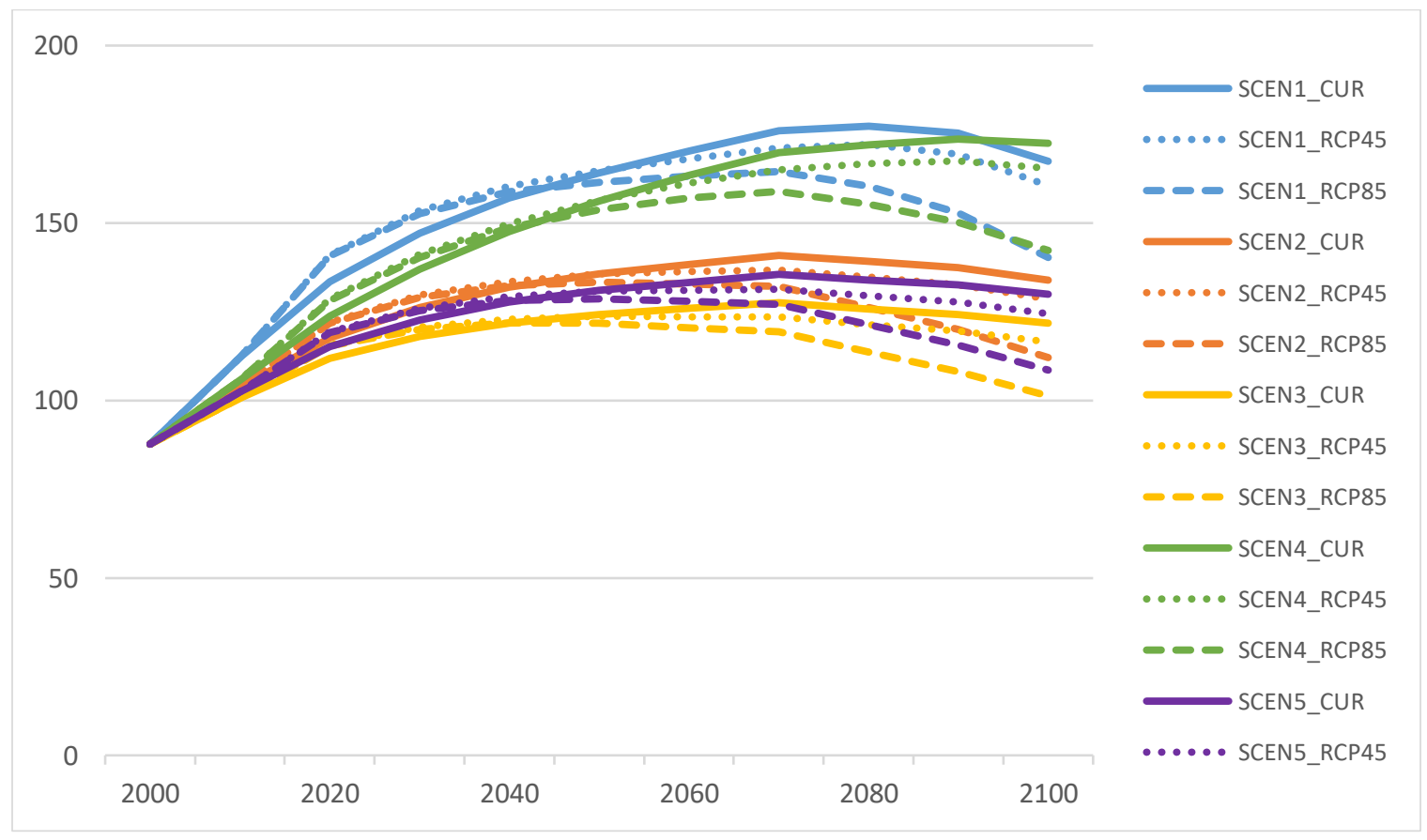

Figure 6. Total basal area ( $\left(f^{2} / a c r e\right)$ for the East Gulf Coastal Plain region. 


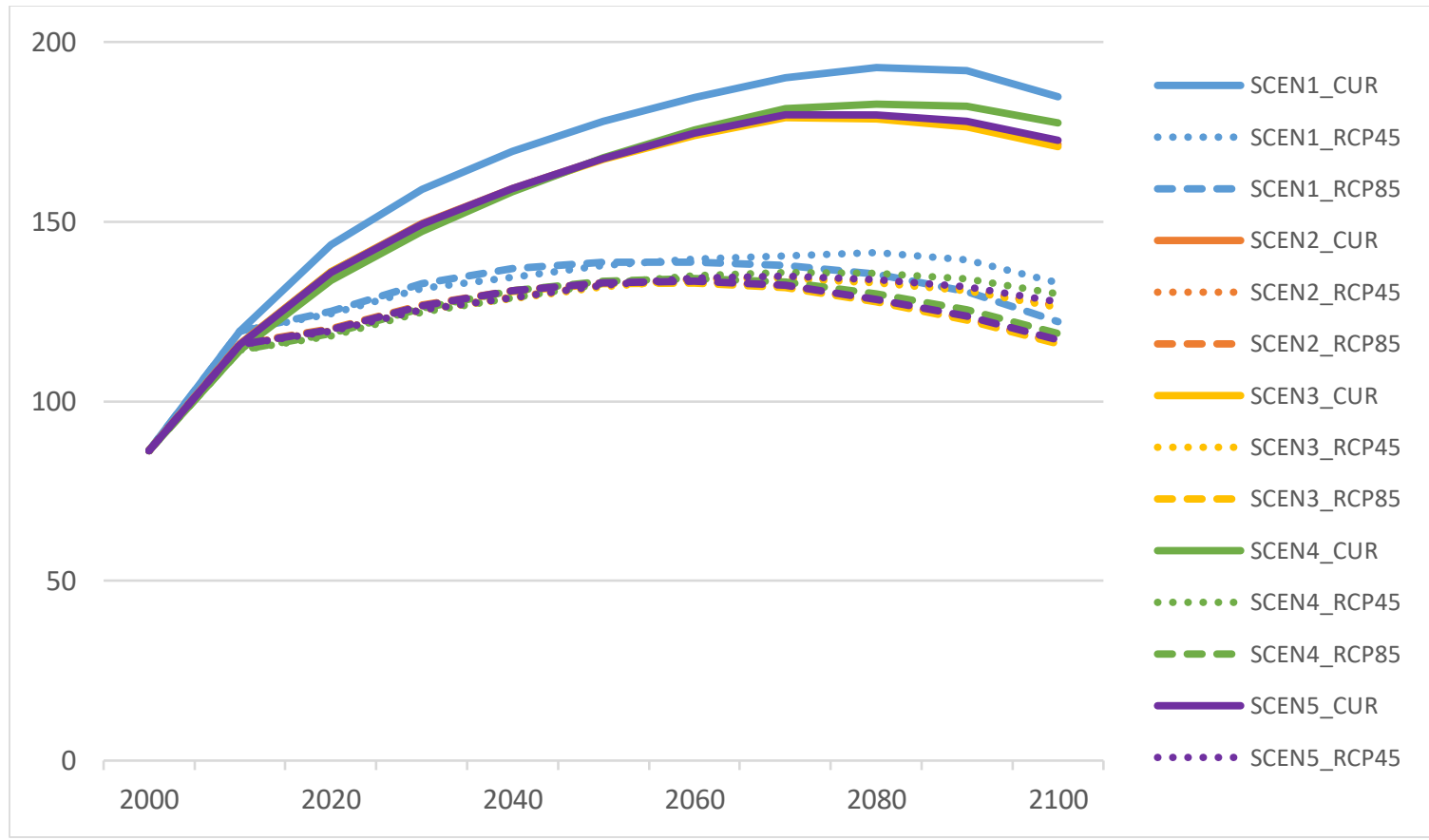

Figure 7. Total basal area (ft $\left.{ }^{2} / a c r e\right)$ for the Interior Highlands region.

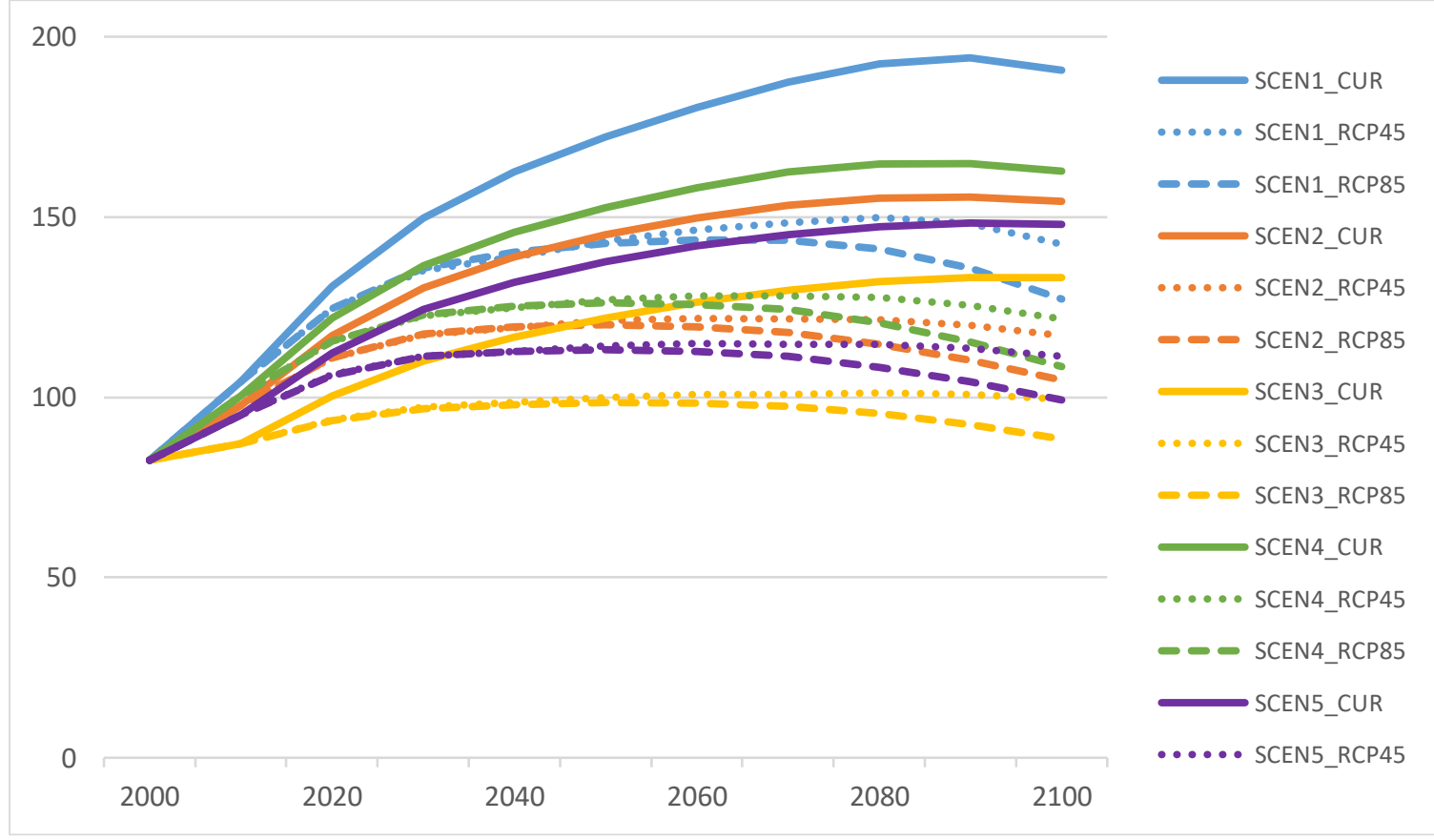

Figure 8. Total basal area (ft/acre) for the Mississippi Alluvial Valley region. 


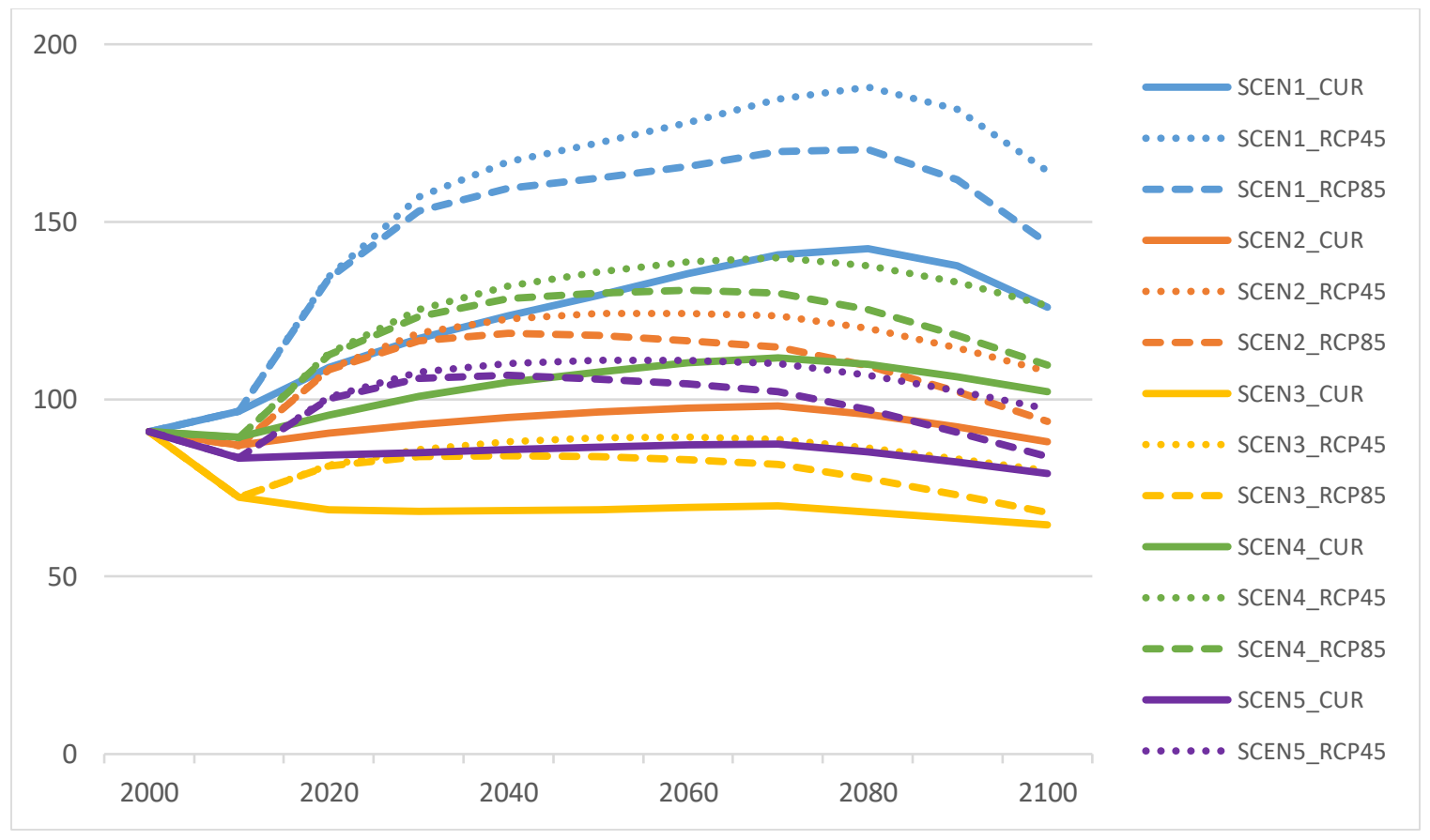

Figure 9. Total basal area (ft/acre) for the Gulf Coast region. 


\section{WhiteOak}

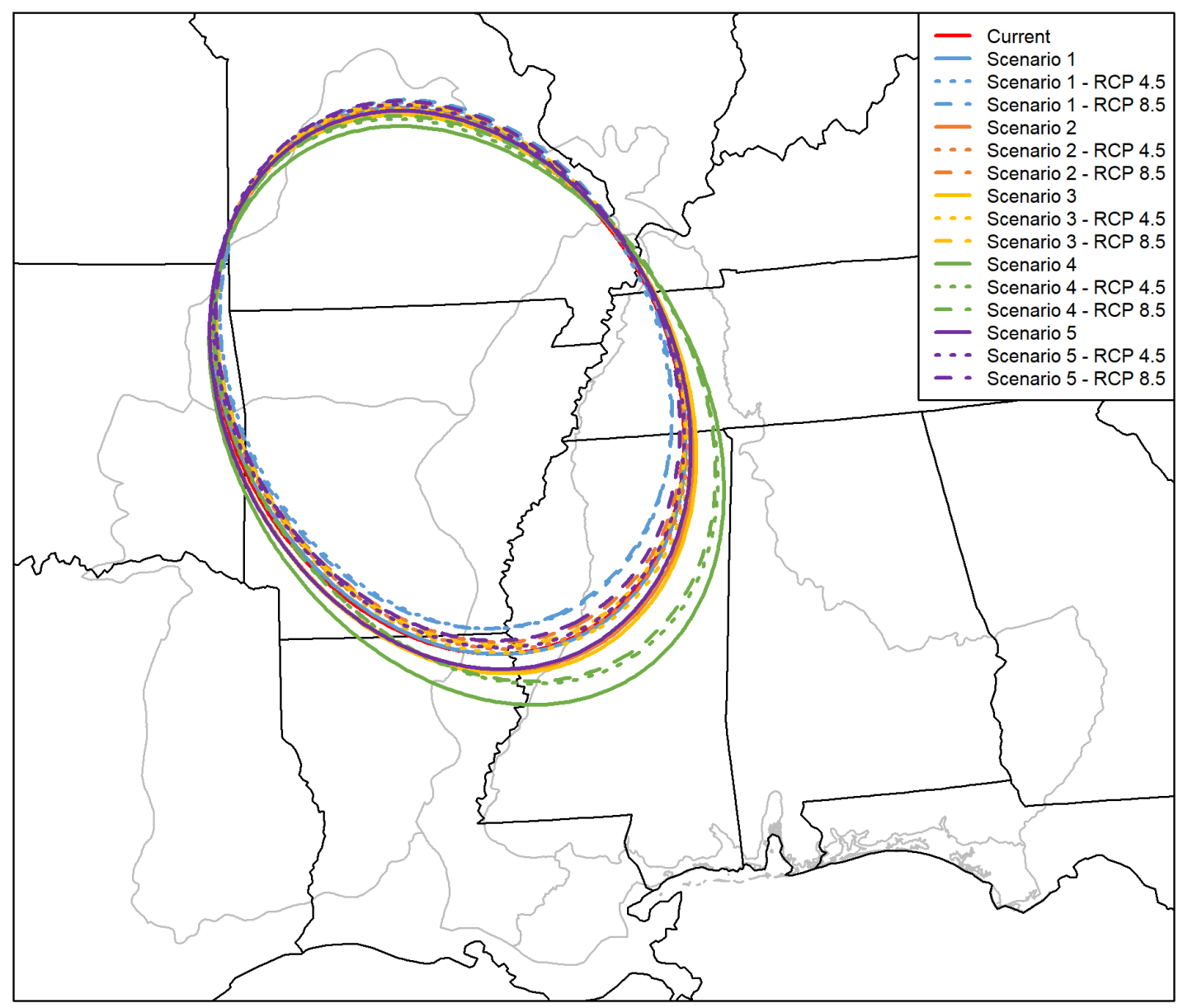

Figure 10. Ellipses containing 1 standard deviation weighted by importance value of white oak for the present-day distribution and under five adaptation scenarios and three climate scenarios. 


\section{ShortleafPine}

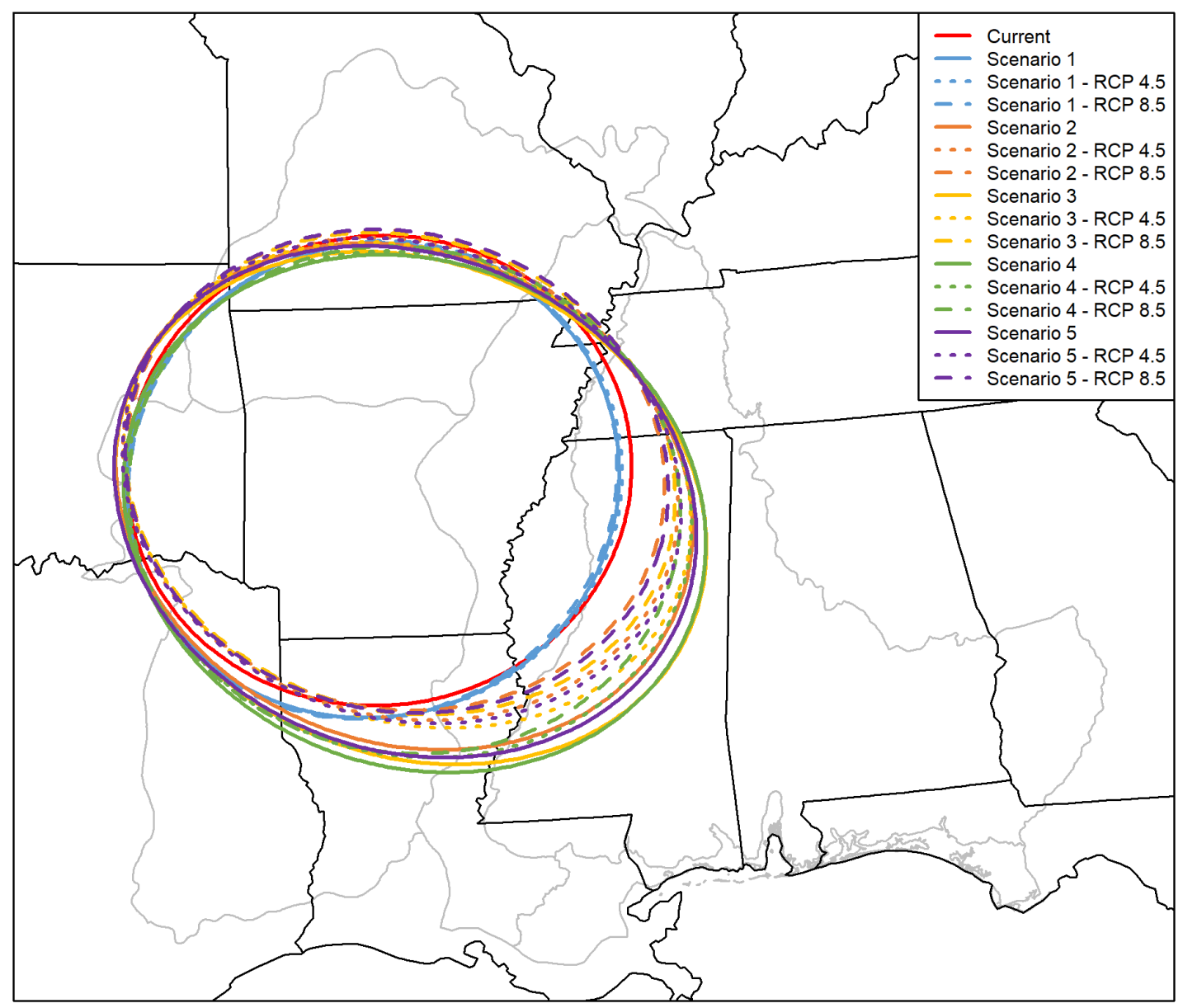

Figure 11. Ellipses containing 1 standard deviation weighted by importance value of shortleaf pine for the present-day distribution and under five adaptation scenarios and three climate scenarios. 


\section{LoblollyPine}

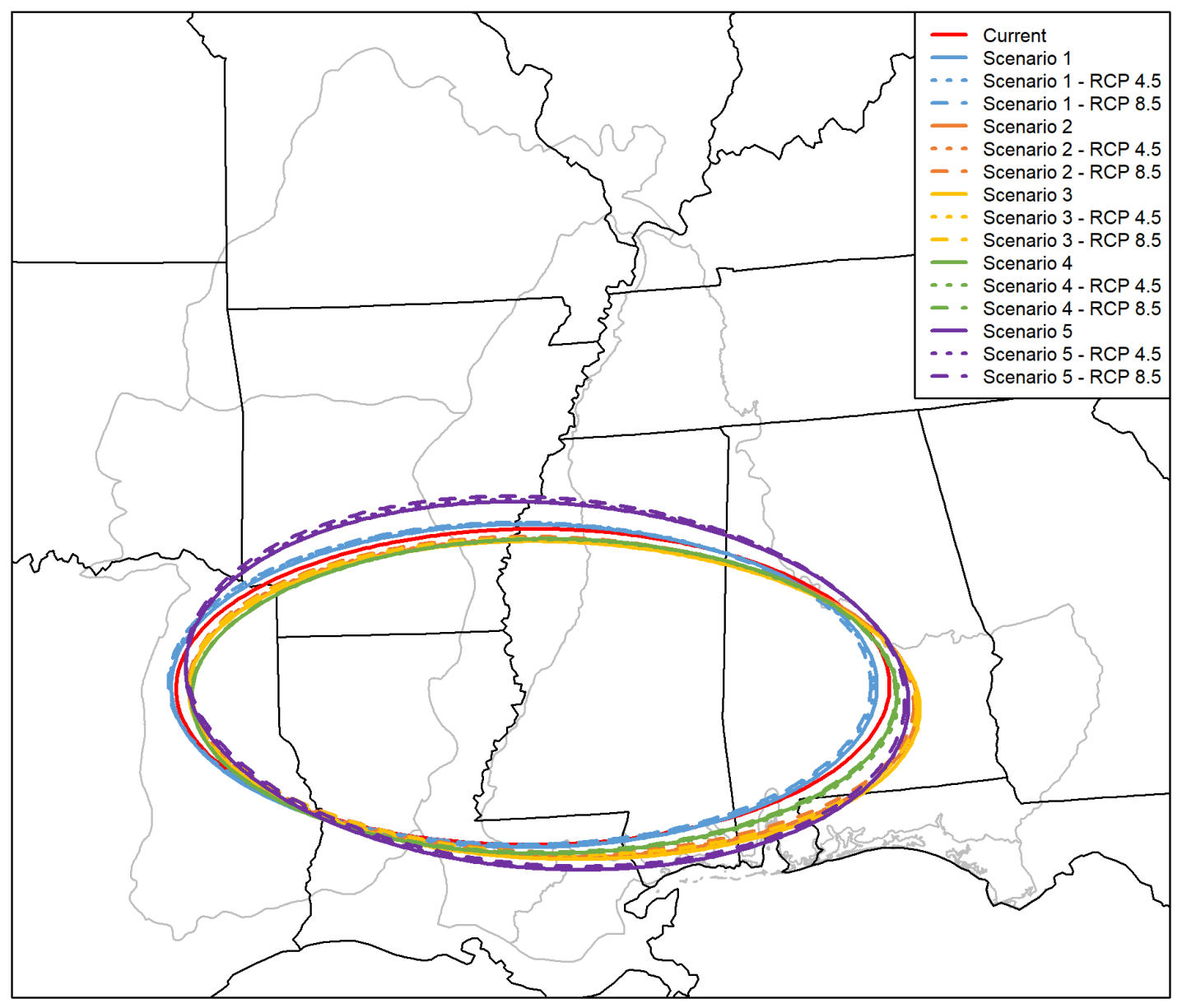

Figure 12. Ellipses containing 1 standard deviation weighted by importance value of loblolly pine for the present-day distribution and under five adaptation scenarios and three climate scenarios. 


\section{LongleafPine}

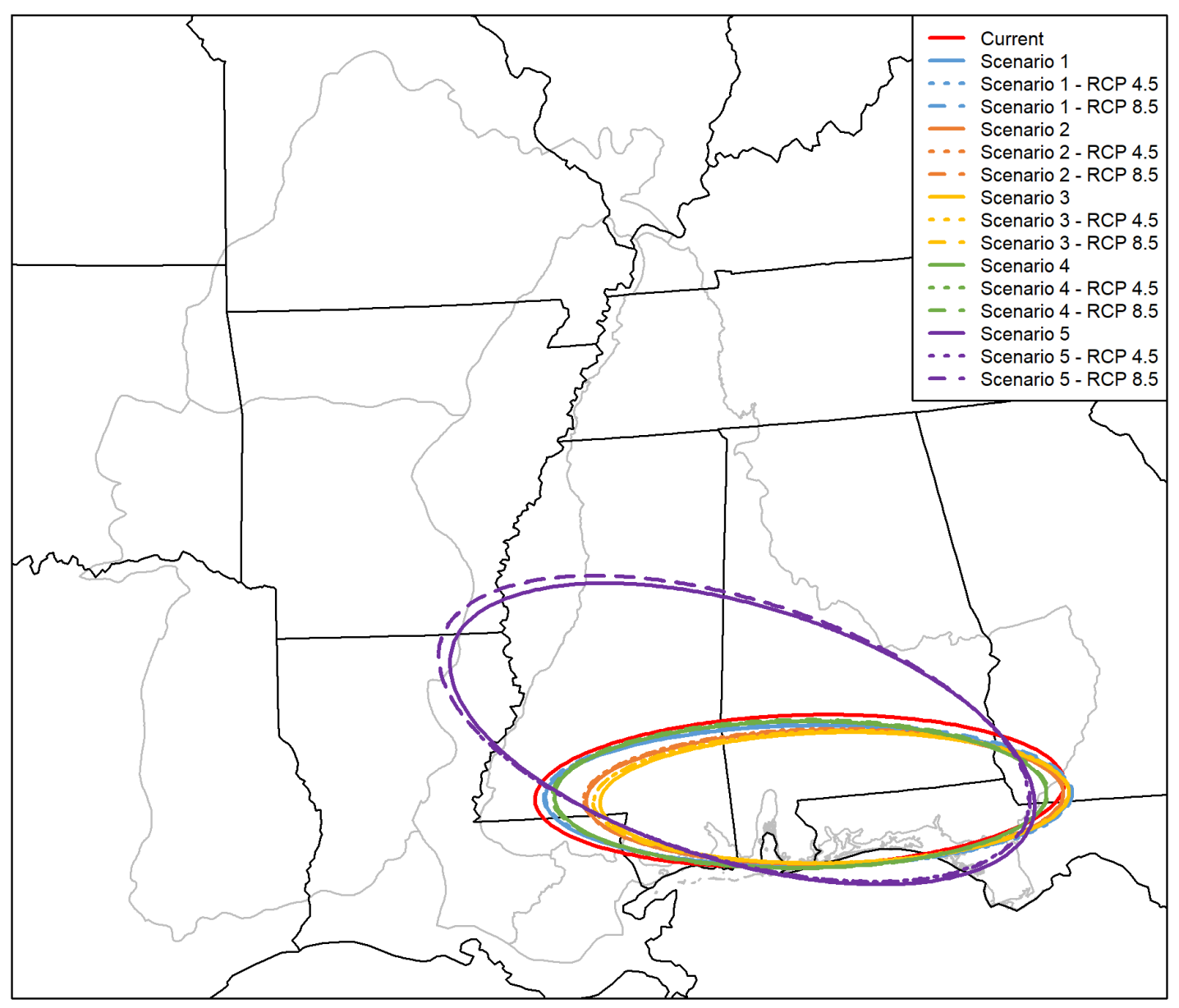

Figure 13. Ellipses containing 1 standard deviation weighted by importance value of longleaf pine for the present-day distribution and under five adaptation scenarios and three climate scenarios. 


\section{SlashPine}

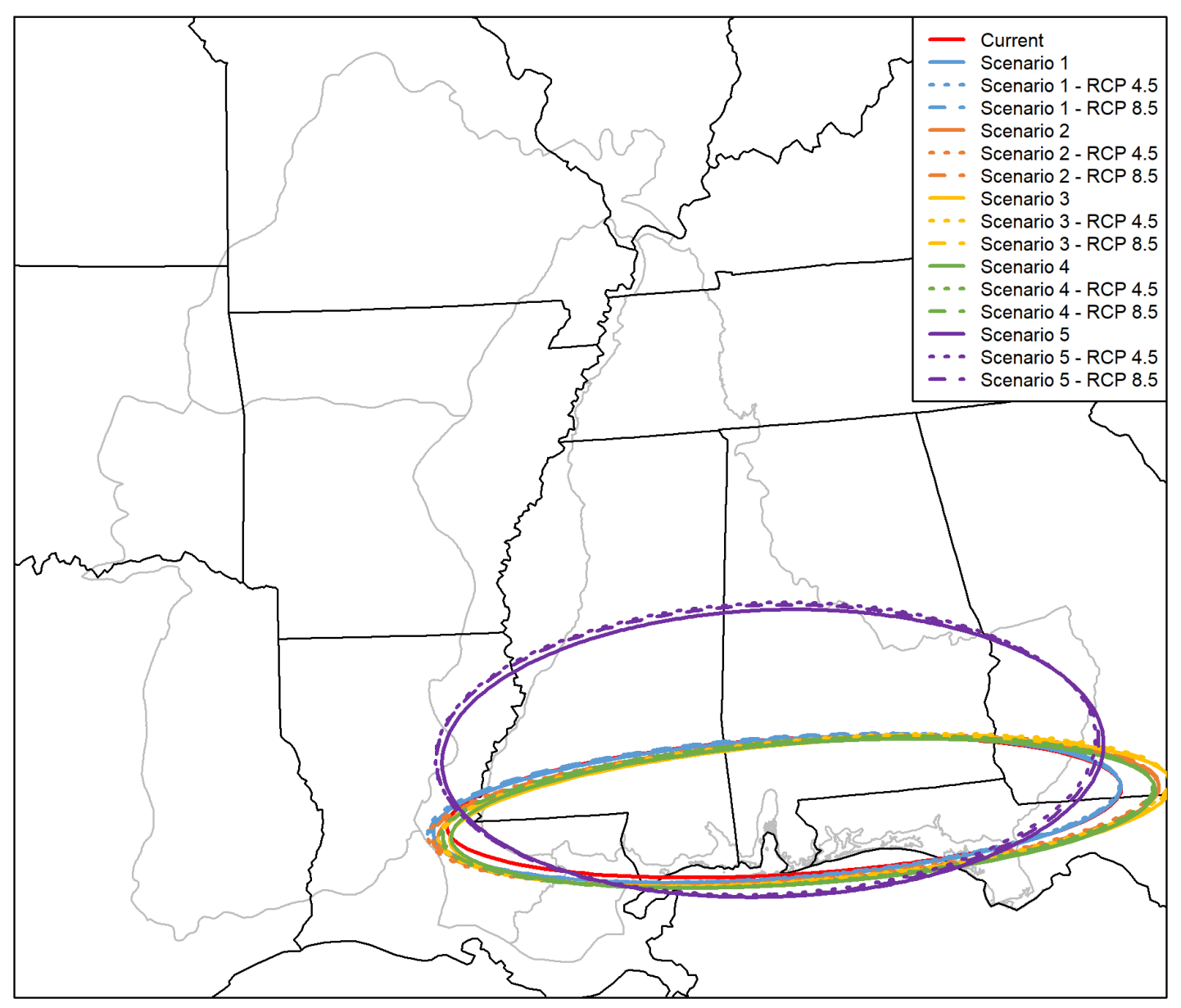

Figure 14. Ellipses containing 1 standard deviation weighted by importance value of slash pine for the present-day distribution and under five adaptation scenarios and three climate scenarios. 

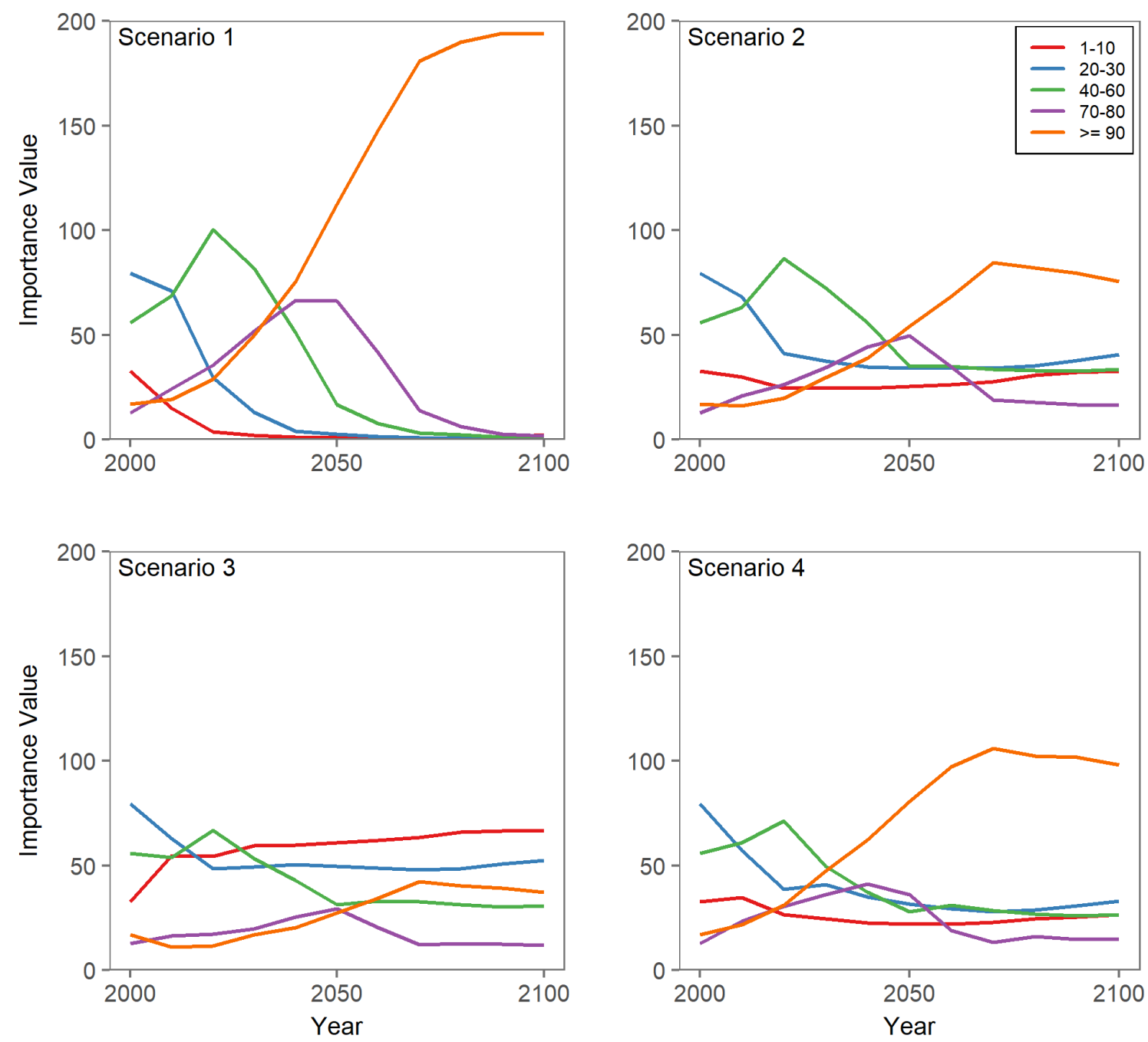

Figure 15. Age class importance values for the study area under four adaptation scenarios. 


\section{VITA}

Jacob Fraser was born and raised in Columbia Missouri. He graduated from Rock Bridge high school and pursued a B.S. degree in forestry and GIS certificate at the University of Missouri. During his time as an undergraduate he became interested in landscape ecology and forest modeling and returned to the University of Missouri to pursue a master's degree in forestry and landscape ecology. He completed his master's degree in 2012 and began working as a research specialist in the School of Natural Resources at the University of Missouri while also working towards a Ph. D which was completed in 2018. Jacob is currently a Post-Doctoral Research Fellow in the natural resources department at the University of Missouri. 